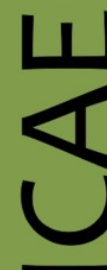

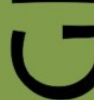

ex Instituto Archaeologico Universitatis de Rolando Eötvös nominatae

O

$\overrightarrow{0}$

山

$\leftarrow$

I

$\cup$

ه

$\leftarrow$

u

Ш

Z

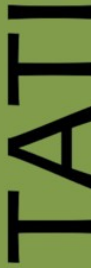

œ

ш

n

n

$\varnothing$
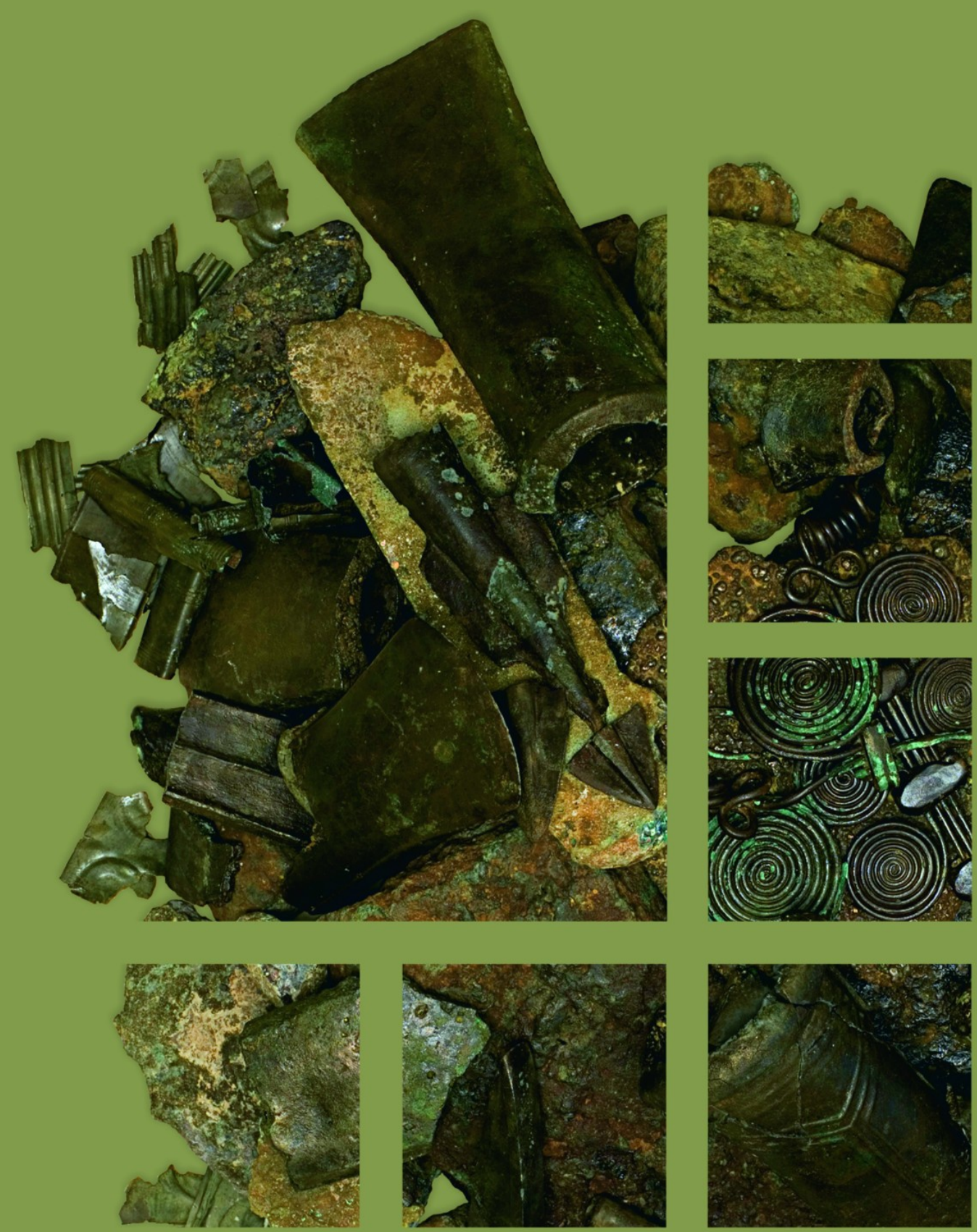


\section{Dissertationes Archaeologicae ex Instituto Archaeologico}

Universitatis de Rolando Eötvös nominatae Ser. 3. No. 2.

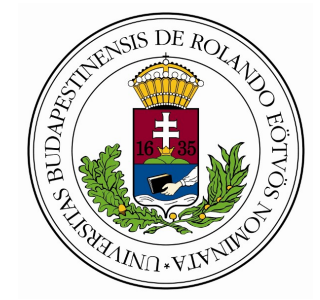

Budapest 2014 
Dissertationes Archaeologicae ex Instituto Archaeologico Universitatis de Rolando Eötvös nominatae

Ser. 3. No. 2.

Editor-in-chief:

DÁvid BARTus

Editorial board:

LÁsZló BARTOSIEWICZ

LÁSZLÓ BORHY

IsTVÁN FELD

GÁBOR KALLA

PÁL RACZKY

MiKLÓs SzABÓ

TIVADAR VIDA

Technical editors:

DÁvid BARTus

GÁBOR VÁCZI

ANDRÁs BÖDŐCS

DÁNIEL SZABÓ

Proofreading:

SZILVIA SzÖLLősI

Available online at http://dissarch.elte.hu Contact: dissarch@btk.elte.hu

$$
\begin{aligned}
& \text { PUBLIC } \\
& \text { KNOWLEDGE } \\
& \text { PROJECT }
\end{aligned}
$$

(c) Eötvös Loránd University, Institute of Archaeological Sciences

Budapest 2014 


\section{Contents}

\section{SElected PAPERS OF THE XI. Hungarian CONFERENCE on Classical Studies}

Ferenc BARNA

Venus mit Waffen. Die Darstellungen und die Rolle der Göttin in der Münzpropaganda

der Zeit der Soldatenkaiser (235-284 n. Chr.)

Dénes GABLER

A belsó vámok szerepe a rajnai és a dunai provinciák importált kerámiaspektrumában

Lajos MATHÉDESZ

Római bélyeges téglák a komáromi Duna Menti Múzeum gyújteményében

Katalin OtTOMÁNYI

Újabb római vicusok Aquincum territoriumán

Eszter SÜVEGH

Hellenistic grotesque terracotta figurines. Problems of iconographical interpretation

András SzABó

Some notes on the rings with sacred inscriptions from Pannonia

István VIDA

The coinage of Flavia Maxima Helena

\section{Articles}

Gábor TARBAY

Late Bronze Age depot from the foothills of the Pilis Mountains

Csilla SÁRó

Roman brooches from Paks-Gyapa - Rosti-puszta

András BöDőcs - Gábor KovÁcs - Krisztián ANDERKó

The impact of the roman agriculture on the territory of Savaria

Lajos JuHÁsz

Two new Roman bronzes with Suebian nodus from Brigetio

\section{FIELD REPORTS}

Zsolt MESTER - Norbert FARAGó - Attila KirÁLy

The first in situ Old Stone Age assemblage from the Rába Valley, Northwestern Hungary

Pál RACZky - Alexandra ANDERs - Norbert FARAgó - Gábor MÁRKus

Short report on the 2014 excavations at Polgár-Csőszhalom 
Preliminary Report on the first season of fieldwork in Berettyóúffalu-Szilhalom

Márton SzILÁgyi - András FüZESI - Attila VIRÁG - Mihály GASPARIK

A Palaeolithic mammoth bone deposit and a Late Copper Age Baden settlement and enclosure

Preliminary report on the rescue excavation at Szurdokpüspöki - Hosszú-dúlö II-III. (M21 site No. 6-7)

Kristóf FüLÖP - Gábor VÁcZI

Preliminary report on the excavation of a new Late Bronze Age cemetery

from fobbágyi (North Hungary)

Lőrinc TimÁr - Zoltán CzAJLik - András BöDőcs - Sándor PuszTA

Geophysical prospection on the Pâture du Couvent (Bibracte, France). The campaign of 2014

Dávid BARtus - László Borhy - Gabriella Delbó - Emese SzÁmadó

Short report on the excavations in the civil town of Brigetio (Szőny-Vásártér) in 2014

Dávid BARTus - László BorHy - Emese SzÁMADó

A new Roman bath in the canabae of Brigetio

Short report on the excavations at the site Szőny-Dunapart in 2014

Dávid BARTus - László Borhy - Zoltán CzAjlik - Balázs Holl -

Sándor PuszTA - László RuPNiK

Topographical research in the canabae of Brigetio in 2014

Zoltán CZAJLIK - Sándor BERECKI - László RUPNIK

Aerial Geoarchaeological Survey in the Valleys of the Mureș and Arieș Rivers (2009-2013)

Maxim MoRDovin

Short report on the excavations in 2014 of the Department of Hungarian Medieval

and Early Modern Archaeology (Eötvös Loránd University, Budapest)

Excavations at Castles Čabrad' and Drégely, and at the Pauline Friary at Sáska

\section{Thesis Abstracts}

Piroska Csengeri

Late groups of the Alföld Linear Pottery culture in north-eastern Hungary

New results of the research in Borsod-Abaúj-Zemplén County

Ádám Bíró

Weapons in the 10-11th century Carpathian Basin

Studies in weapon technology and methodology - rigid bow applications and southern import

swords in the archaeological material

Márta DARÓcZI-SzABó

Animal remains from the mid 12th-13th century (Árpád Period) village of Kána, Hungary

Károly BELÉNYESY

A 15th-16th century cannon foundry workshop in Buda

Craftsmen and technology of cannon moulding and the transformation of military technology

from the Renaissance to the Post Medieval Period 
István RINGER

Manorial and urban manufactories in the 17th century in Sárospatak

\section{BIBLIOGRAPHY}

László BORHY

565

Bibliography of the excavations in Brigetio (1992-2014) 


\title{
Újabb római vicusok Aquincum territoriumán
}

\author{
KATALin OtTomÁnYi
}

ottomanyi.katalin@gmail.com

\begin{abstract}
We already know several vici on the territory of Aquincum, but the name of the pagus and the vicus together is only found on a newly excavated altar-stone from Budaörs. The name of three vici is visible on the inscription. On the main place, most likely as the location of the Terra Mater sanctuary, the vicus from Budaörs, Kamaraerdei-düló, named vicusTeuto(...) is located, and can be called the leading vicus of pagus Herculius. I would like to try to connect the new vici names with excavated settlements. Based on the only definitely identifiable vicus of Budaörs, examining if there are other Roman settlements with similar size and structure in its vicinity. After having regard to the Roman road system and the hydrology of the area, two larger settlements with several stone buildings can be considered in Páty and Biatorbágy. The comparison of these settlements' excavation results can shed some light to the civilian vici's inner structure, periodization and the composition of the population. With this the possibility arises to separate them from the smaller autochthonous villages without stone buildings, called vici beforehand, and the villas with stone buildings. We can summarize that the three vici, what lies in a nearly same distance to each other $(6 \mathrm{~km})$, has a similar location (next to the stream and the road), age and periodization. All of them has Celtic origins and a continuous development through the 1st century. The construction of stone buildings started early, in the first third of the 2nd century under the rule of Hadrianus. They were destroyed during the Marcomannic Wars and after the rebuilding in the Severus era the former vici continued its existence, getting even stronger, instead of establishing a villa in the location of the autochthonous village. In the 250s a Barbarian attack occurred as the coin hoards show (Biatorbágy and Budaörs), then the settlements life continued from the last third of the 3rd century to the end of the 4th century with a continuous development. The destruction of the settlements is signified by the skeletons found in pits, and other finds that can be dated to the beginning of the 5th century, such as bone comb, polished pottery, etc. Based on the stone inscriptions and jewellery, the population consists of the local elite as well as the veterans and other elements from the western part of the Empire in the early Roman period. After the Marcomannic Wars the inscriptions show the leading significance of the magistrates and soldiers from Aquincum. In the beginning of the 5thcentury foreign, most likely Germanic, elements are present mixed with the surviving Roman population. The structural characteristics of the vici, like inner paved roads, stone curtains, are present in all three settlements. We can assume the presence of shrines as well based on the altar-stones, but public building can be found only in Budaors. In the construction culture, structure and the population composition surpasses the villages without stone construction, but their size and legal standing doesn't reach the standard of cities. They are definitely not villas. The richest of the three was Budaörs, the central vicus of pagus Herculius. The Roman settlement excavated in Budaörs - Kamaraerdei-düló, standing for nearly 400 years, is a new evidence for the existence of the Roman established administrative units pagi and vici in Pannonia.
\end{abstract}

A rómaiak egy új provincia megszervezésekor felmérték a területet és territoriumokat, autonóm, önálló rendelkezési joggal bíró területeket jelöltek ki rajta. Külön territoriuma volt a bennszülött civitasoknak, ld. civitas Eraviscorum, a városoknak, jelen esetben Aquincumnak és a katonaságnak. A városi territoriumokon belül kisebb közigazgatási egységek, pagusok (körzetek) és ezen belül ún. vicusok, falvak/települések alakultak ki. Erre a felosztásra utal néhány pannoniai katonának a sírkövön feltüntetett származása (origo), ahol a provincia név után a városi territorium, majd a pagus és vicus név következik. ${ }^{1}$

1 Kovács 1999, 114-115; KovÁcs 2013, 136: pl. natus ad Aqus Balizas pago Iovista vico Cocconetibus (CIL VI 3297); Cibalis ex Pannonia i[nf(eriore)] pago August(o) vico S[---] (CIL II. 127a) stb. 
A vicus kifejezést a hazai kutatás eddig vagy a katonai jellegű, auxiliáris tábort kísérő településre (vicus militaris) alkalmazta, vagy a civil, bennszülött, falusi telepekre használta. Ez utóbbiaknál gyakran a villa ellentéteként, kőépítkezés nélküli szegényebb települések jelölésére. ${ }^{2} \mathrm{Az}$ ókori forrásokban tükröződő vicus fogalom azonban szemben áll ezzel a szegényes falu elképzeléssel. Az irodalmi szövegekben a vicus eredetileg egy ház blokkot, ház negyedet jelentett a városon belül, pl. Plautusnál olvasható Rómán belül a vicus Tuscus. Caesar a galliai, kelta falvakra használja a vicus elnevezést. Más irodalmi művekben az oppidum ellenpárjaként szerepel, mint városi privilégiumokkal nem rendelkező és nem erődített, nyílt színi település. Később a vicani kifejezés már falusit jelent és a szótárban is ez szerepel. De a vicus egyszerű faluként való fordítása félrevezető. A vicus szó a törvényszövegekben a forum és conciliabulum szavak megfelelőjeként tünik fel. A conciliabulum egy gyülés (concilium) helye, a forum ezzel szemben kereskedelmi funkciót is betölt, ami egy piacot, szentélyt stb. feltételez. Mindez jelzi, hogy a vicusoknak adminisztratív és kereskedelmi jelentősége van, de nem kaptak városi kiváltságokat és nem veszik körbe védművek. ${ }^{3}$ A vicus szónak tehát több jelentése van és régészetileg is többféle módon mutatkozhat meg.

A vicusok különböző régészeti megjelenése részben időrendi, részben földrajzi különbségekkel magyarázható. Kezdetben, a Kr. u. 1. század második felében valóban egyszerü bennszülött falvak, kőépítkezés nélkül (hisz ekkor még a katonai táborokban sincsenek kőépületek). Ilyen korai vicusra példa Aquincum, amikor még nincs pagus, csak a civitas Eraviscorum területén lévő vicust említi egy felirat. ${ }^{4}$ Majd némelyikből a 2. század elejére katonai canabae ill. municipium alakul ki. Mások megmaradnak vidéki, civil településnek, de elindul a nagyobb mértékű romanizáció, és megjelenik a kőépítkezés, akár már a Hadrianus-, vagy az Antoninus-korban. Ez elsősorban Aquincum környékén bizonyítható, ld. Budaörs, Páty. ${ }^{5}$ Ugyanakkor Pannonián belül máshol is vannak nagy kiterjedésű, foútvonal mellett fekvő telepek, amelyeken fennállásuk több évszázada alatt sem jött létre kőépítkezés, ld. Ménfőcsanak, Mosonszentjános, Bátaszék stb. ${ }^{6}$ Méretük alapján ezek ugyancsak vicusnak tarthatók. A kőépületek hiánya talán a kőben szegény vidékre vagy más helyi sajátosságra vezethető vissza. A legutolsó csoportot a kisebb, rosszabb földrajzi helyzetben lévő, eldugottabb falvak alkotják, amelyek a 2. század végére vagy megszűnnek, vagy továbbra is megrekednek a kezdeti, fejletlenebb színvonalon. Kérdés, hogy ezeket lehet-e még vicusnak nevezni, vagy a római közigazgatáson belüli legalsó szintet képviselik, az adminisztratív és kereskedelmi központot alkotó vicusok alá beosztva, esetleg a villagazdaságokban dolgozó colonusok lakhelyei, stb. ${ }^{7}$ A további kutatások, nagyfelületű ásatások és új feliratok esetleg megoldhatják ezt a problémát.

Jelen tanulmányban három olyan Aquincum környéki vicust szeretnék bemutatni, amelyek kitágítják az egyszerủ falu fogalmát, bebizonyítva, hogy a vicusok a városok és a kis bennszülött falvak közötti lépcsőfokot jelentik.

2 GABler 1993-1994, 150-151; KovÁcs 1997-1998.

3 TARPIN 1999, 4-6; KovÁcs 2002b; Pannoniából a pagus és vicus elnevezésen kívül más civil településre utaló név pl. conciliabulum, forum stb. nem ismert (KovÁcs 2013, 138).

4 Kovács 2013, 136. Hadrianus előtti felirat: Senio ... in c(ivitate) Er(aviscorum) in Acinco d(efunctus).

5 OTTOMÁNYi 2007a, 209-219; OtTOMÁNYi 2012a.

6 SzőNYI 1996; SzŐNYI 2005; MAgYAR 2014

7 GABler 2003, 241; Bíró 2007, 26. 


\section{A pagus Herculius vicusai}

Pannoniában több helyről maradtak fenn pagus és vicus elnevezések - pl. Carnuntum és a dél-pannoniai városok ${ }^{8}$ - de a mai Magyarország területén pagus és vicus együttes elnevezése csak egyetlen helyről, Budaörsről ismert (Fig. 1.1-2).

Budaörs, Kamaraerdei-dűlőben a római település - mind a pagus, mind a rajta lévő vicusok ókori nevét megőrizte egy oltárkő. Ezt az oltárkövet a 3. század közepén Philippus Arabs és fia, II. Philippus uralkodása idején állították Terra Maternek, a Herculesről elnevezett körzet (pagus) vezetői. A kövön szereplő pagus Herc(ulius)-hoz tartozó vicusok képviselői gyűltek egybe egy ünnepi alkalommal (valószínủleg Róma ezer éves fennállásának megünneplésére, 248. április 21.-én), hogy oltárt szenteljenek a császárok és az istennő tiszteletére. ${ }^{9} \mathrm{~A}$ feliraton három vicus neve maradt meg (a töredék alapján a felsorolás még folytatódott). A három, név szerint is ismert vicus a következő: vicus Teuto, Teuto(nis) vagy Teuto(nianus), nevét a kelta Teuto személynévből képezték. Hasonló kelta névadás Aquincum környékén más feliratokon is megőrződött a 3. századig (pl. Iuppiter Teutanus). A vicus Bataion(is) neve ugyancsak az őslakos, Bataio személynévből képzett. A harmadikként említett vicus Anarti(orum), a kelta anartius nép egyik csoportjának, az Alföld északkeleti részéről Pannoniába, közelebbről Aquincum környékére való betelepítésére lehet bizonyíték. Elképzelhető, hogy a vicusok felsorolásában a Terra Mater szentélynek helyet adó budaörsi vicus került a leghangsúlyosabb első helyre, ezért a feltárt település valószínűleg a vicus Teuto(...) nevet viselte. A pagust az eraviscus területen közkedvelt Herculesről nevezték el, akinek a pagus központi vicusában, Budaörsön álló szentélyére egy onnan előkerült oltárkő is utal (Fig. 16.4). A Terra Maternek szentelt oltár végén valószínűleg szerepeltek a pagus vezető tisztségviselői, az oltárállítással megbízott magistri is. ${ }^{10}$

Aquincum város territoriumán több vicus neve is ismert (pagus megnevezés nélkül). ${ }^{11}$ Közülük biztosan helyhez köthető a Békásmegyeren előkerült oltárkő alapján a vicus Vindonianus ill. egy intercisai felirat nyomán a vicus Caramantesium. Pontosabb helymeghatározás nélkül, Budapest területéről származik még a vicus Basoretensis, ${ }^{12}$ a vicus Res (a Bécsi úti temetőből), a vicus $X$ (ami lehetett egy városnegyed is) és Szigetszentmiklósról a vicus Cuetro. ${ }^{13}$ Ehhez járult most a budaörsi oltárkő alapján a pagus Herculius, amely Aquincum territoriumának délnyugati körzetét foglalta magába. Rajta minimum négy, de lehet, hogy több vicussal, amelyből háromnak a nevét ismerjük is (Fig. 1.3). Természetesen ennél jóval több vicus létezett a város territoriumán, amelyek neve nem maradt ránk. ${ }^{14}$ Arra nincs adatunk Pannoniából, hogy egy pagus területe hány vicust foglalt magába. Valószínúleg a vici száma pagusonként eltérő lehetett.

8 MrÁv - OtTomÁNYi 2005, 79-80; KovÁcs 2008, 58.

9 Mráv - OtTOMÁNYi 2005, 76-78; Mráv 2014, 79-81.

10 MrÁv - OTTOMÁNYi 2005, 79-100.

11 Zsidi 2004, 175; Kovács 2008, 58 (további irodalommal); MrÁv - OtTomÁnYi 2005, 101-102.

12 Régebben a Kiscelli magaslat környékére lokalizálták, de ez nem bizonyított (MRÁv - OтTOMÁNYi 2005, 101, 139. jegyzet).

13 Kovács 2002a.

$14 \mathrm{Pl}$. a későbbi Aquincum municipium helyén is csak egy civil vicus volt kezdetben (ZsıDi 2004, 175-177). A Gellérthegytől délre, a mai Lágymányos területén ugyancsak egy nagy kiterjedésű település, vicus húzódott, ipari jellegủ objektumokkal, lakóházakkal és kövezett utakkal (BESzÉDEs 2010). A Solymár-Krautgarten lelőhelyen feltárt telep esetében sem villáról, hanem az Aquincum - Brigetio út mellett fekvő bennszülött telepről, vicusról van szó, ahol a 2. század elején új birtokos réteg emelkedett ki a helyi arisztokráciából, hozzájuk köthetők a kőépületek (KoczTUR 1985, 80-81). Budatétényben is volt egy nagy, civil település a limesút mentén, kőépületekkel, gazdasági objektumokkal (SzIRMAI 1984), stb. 
A budaörsi feliraton szereplő nevek és a régészeti feltárások során megismert települések összekapcsolására szeretnék jelen tanulmányban kísérletet tenni, kiindulva az egyetlen biztosan azonosítható, budaörsi vicusból, megvizsgálva, hogy környezetében milyen más hasonló nagyságú és szerkezetű római település található. Fontos szempont a római kori út és vízhálózat figyelembe vétele is.

A nyugati provinciákban elsősorban a fő kereskedelmi útvonalak mellett, vagy stratégiailag fontos helyeken fekvő telepeket tartják vicusnak. ${ }^{15}$ Másik alapvető feltétel pedig a telepek vízhez való közelsége. Budaörsön mind a két tényező megtalálható: ${ }^{16}$ a vicus az egyik, Aquincumba tartó belső pannoniai foútvonal, a Savaria - Floriana - Aquincum útvonalon (It. Ant. 263.3) helyezkedett el (Fig.1.4). Valószínűleg ebbe kötött be a Velencei-tó térsége után, a Sopianaeból, Gorsium érintésével Aquincumba tartó út is (It. Ant. 264.21). ${ }^{17}$ Továbbá a Hosszúréti-patak partján, hosszan elnyúlva található. E patak mellett, az ún. Rózsavölgyben feltételezhető út is összekötötte keleti irányban a Duna menti limes-szel (Albertfalva táborával). ${ }^{18}$

A Hosszúréti-patak völgyében nyugat felé továbbhaladva, kb. 6 km távolságra Biatorbágy, Kukorica-dűlőben a 2007-2008. évi, K.Ö.SZ. által vezetett feltárások egy nagy kiterjedésű római kőépítkezéses telepet, az ásató szerint feltehetően vicust hoztak a napvilágra. ${ }^{19}$ Továbbhaladva északnyugati irányban, hasonló távolságra, a Füzes-patak partján, Páty, Malomdűlőben egy ugyancsak vicusnak tartható település következett (Fig. 2.1). ${ }^{20}$ Feltűnő a három vicus közti majdnem hasonló távolság, ami alapján mindegyik vicus egy kb. $3 \mathrm{~km}$-es sugarú kör közepén helyezkedhetett el. Ez azonban csak elmélet, mivel egyik vicus határait sem tudjuk pontosan meghatározni. Érdemesebb azt megvizsgálni milyen egyéb római kori telepek illetve villák, esetleg temetkezések, oltárkövek vannak a feltárt vicusok közelében. Mik tartozhattak a vicus területéhez, meddig terjedhetett ki a hatásköre?

Budaörsön, a Kamaraerdőben feltárt 2. lelőhelyen túl a felszíni leletek alapján csak két kisebb településnyom van, a Kamaraerdői Törzsgyümölcsösben és a Csíki-szőlőkben illetve nyugat felé Törökbálinton egy településrészlet a Hosszúréti-patak partján, a két vicus határán. ${ }^{21}$ Két kisebb temetkezés ${ }^{22}$ és három szentély tartozhatott még a vicushoz. Ez utóbbiak közül a vicus határait jelölhetik északnyugaton, a Csíki erdőben legújabban előkerült, Libernek szentelt oltárkő, ${ }^{23}$ illetve északkelet felé a Budaörsi út - Rupphegyi út kereszteződésében 2007-ben feltárt, LT D előzményű, többrétegű településrészlet, ahol a 2-3. században, az észak - déli irányú sóderes út mellett egy kis, szögletes, útállomásként vagy szentélyként értelmezhető épület állt (közepén oszlopbázis és felirat nélküli oltárkő). ${ }^{24} \mathrm{~A}$ harmadik szentély helye ismeretlen, ez az ún. „Szőlőhegyen” lévő Mithras szentély. ${ }^{25}$ Mindezeket térképre vetítve (Fig. 2.2) és figyelembe véve, hogy Budaörs 6 km-es körzetében keleti irányban Albertfalván már katonai tábor volt, a fent említett $3 \mathrm{~km}$ sugarú kör valóban megfelelhetett a vicus territoriumának (kb. 28 km²).

\footnotetext{
15 TARPIN 1999, 4-6.

16 OtTomÁnYi 2012a, 381.

17 То́тн 2003, 220 (egyik útvonal keleti szakasza sincs még véglegesen tisztázva); Visy 1994, Abb. 19.

18 MrÁv 2012, 1. kép 2; Régészetileg nem foghatók meg ezek az utak. Valószínűleg a vicusok és villák is kisebb bekötőutakkal csatlakoztak a föúthoz.

19 MiкLÓSITY SzŐKE 2009, 152.

20 OTTOMÁNYi 2007a, 209-219.

21 Budaörs: MRT 7, 5/3, 12. lh; Törökbálint: MRT 7, 36/17. lh.(Hosszú-rétek).

22 MRT 7, 5/9-10. lh. (Budaörs, Rózsa u. 7. és Vasútállomás, Kamaraerdő-dűlő).

23 Borhy - BARTus - StiBrÁnYi 2012, Fig. 5-9. Tartozhatott valamelyik budakeszi villagazdasághoz is.

24 Hárshegyi 2008, 162, 3. kép; Mráv 2014, 94.

25 MRT 7, 66.
} 
A budaörsi vicus központi részén 2002-2003-ban egy mintegy 11 hektáros, nagyrészt összefüggő terület került feltárásra, ami a temetővel és a kutatóárkokkal együtt kb. 19 hektár. Kelet és nyugat felé, a patakkal párhuzamosan még folytatódott a beépített rész. Méretét tekintve akár egy kisebb római városnak is megfelel. ${ }^{26} \mathrm{~A}$ vicuson belüli magánbirtokok határainak jelölésére szolgálhattak a határkövek, pl. Budaörsről Ulpius Karusnak két határköve is előkerült, másodlagosan beépítve (Fig. 4). ${ }^{27}$

A biatorbágyi vicushoz több, a Topográfiában különálló lelőhelyként jelölt telep és villagazdaság is tartozhatott, a Hosszúréti-patak északi és déli partján, sőt Törökbálintra is átnyúlt a lelőhely ${ }^{28} \mathrm{Az}$ M1 és M0 autópálya találkozásánál, kb. 28 hektáros területen hét korszak leletei kerültek elő 2007-2008-ban. Összefüggően 6,5 hektár lett feltárva, de ennek csak egy kis része tartozott a római korba. ${ }^{29}$ Továbbá az M0 autópálya szélesítésénél, a torbágyi 1 . és a törökbálinti 19. lelőhelyeken előkerült, egymást merőlegesen keresztező árok rendszerek tartozhattak még ehhez a telephez. Valószínűleg a vicus belső tagolására szolgáltak, esetleg birtokhatárokat jelöltek. ${ }^{30}$ Körülötte csak Budakeszin illetve jóval délebbre, a Füzes-pataknál van egy villagazdaság. ${ }^{31}$ A vicushoz való tartozásuk kérdéses (Fig. 2.1-2).

A Páty-Malom-dűlőben lévő, vicusnak tartható 8-9. lelőhely északon a mai Páty községig tart, déli irányban pedig átnyúlik Biatorbágyra (Fig. 3.1). Itt, a Füzes-patak mentén, Biatorbágy-Káposztás-dűlőben két római telep tartozik hozzá, ahonnan legutóbb egy ezüst berakásos kis bronzszobrocska került elő a felszíni kőmaradványok között. ${ }^{32}$ A vicus központi részén van egy kb. $2 \mathrm{~km}$ hosszú és 250 m széles, a patakparton hosszan elnyúló település (kb. 50 hektár). Ebből mindössze 9 hektár, alig ötöd része lett megkutatva 1982-1984 és 1997-1999-ben. ${ }^{33}$ Nem ismerjük a feltárt telep viszonyát a többi Pátyon található kőépülettel rendelkező villagazdasághoz ill. kőépület nélküli kisebb telephez sem. Északkeleti szélén található a forrásszentély, ahonnan egy Nympháknak állított oltár került elő, délkeleten pedig egy kis, talán útállomásnak tartható épületnyom. ${ }^{34}$ Amennyiben a vicus egy zárt központi részből és több lazán hozzá kapcsolódó villagazdaságból állt, ezek a távolabbi épületek is tartozhattak a vicus területéhez. Nyugat felé, a Békás-patak völgyében egy sorban elhelyezkedő villagazdaságok ${ }^{35}$ már valószínűleg egy újabb vicus részei, vagy önálló fundusok voltak (Fig. 2.1). Ezt a kérdést csak a további ásatások dönthetik el. A Pátyon előkerült temetkezések és szórvány feliratos kövek is a vicus területéhez tartozhattak. ${ }^{36}$

26 Mursella municipiuma 5-6 hektárnál nem lehetett nagyobb, a temetőkkel együtt is csak 10 hektár. Bassiana 19, Vindobona, Brigetio 20 hektár volt (SzŐNYI 2008, 45; PócZY 2004, 163).

27 Mráv 2014, 108-109; KovÁcs 2013, 139-140.

28 Torbágy: MRT 7, 34/1, 2a, 8, 19. lh. (Hosszú-rétek, Kelényi-tanya). Törökbálint: MRT 7, 36/19. lh. (Kukorica-dűlő).

29 MikLósity SzőKe 2010 (Biatorbágy, Kukorica-dűlő, KÖH azonosító: 57 703).

30 MRT 7, 34/1. lh: Hosszú-rétek (római telep), ahol a 2003-ban folytatott feltárás során derékszögű árokrendszerek nyomai rajzolódtak ki tegulás, köves betöltéssel. Az árkokat néha kőrakások is kísérték (REMÉNYI - TóTH 2004, 163, 1. kép); RAJNA - KovÁcs 2010, 375: az M0 autóút keleti oldalán a tervezett körforgalom területén egy hatalmas méretủ árokrendszer feküdt (római érmek és fibulák). A habarcsdarabok alapján a villagazdasághoz tartozhatott (MRT 7, 34/8. lh: Hosszú-rét, római villagazdaság, 2-4. század).

31 Budakeszi: MRT 7, 4/3-4. lh; Bia: MRT 7, 1/4. lh (Öreg-hegy); ОттомÁNyi 2007b, 326, 3. térkép: Pest megye területén található római telepek és villagazdaságok térképe a topográfia alapján.

32 MRT 7, 34/9, 14. lh;REPISZKY 2004, 166; OtTOMÁNYi 2010, 149-150.

33 OTTOMÁNYi - GABLER 1985; OTTOMÁNyi 2007a, 25.

34 Villagazdaságok: MRT 7, 13/19. és 29. lh. (Laposi-dűlő, Belterület); Kőépítkezés nélküli telepek: 13/1, 4, 21, 26, 28. lh; Forrásszentély: 13/3. lh (Főkút-alja); Útállomás?: 13/10. lh. (Nagy-hegy); OттомÁNYi 2007a, 215-216.

35 MRT 7, 13/15. lh. (Páty, Alsósori Szabad földek) és 1/36-39. lh. (Bia, Herceghalom, Pátyi-domb, Kozáromi-domb); OTTOMÁNYI - GABLER 1985, 185-189.

36 Temetkezés: 13/1. lh. (Lövöldöző): 2-3-századi sírkövek, késő római sír (Mráv 2007, 409, 412; ProHÁszkA 2007, 436); 13/4. lh. (Alsó-Hegy-alja): fegyveres lósír (REPISZky 2005); 13/8-9. lh. (Malom-dűlő): 1-4. századi temető (MARóti 2001; OттомÁNYi 2012b); 13/32. lh. (Somogyi Béla u.): késő római téglasír; Feliratos kövek (oltárkövek, sírkövek, mérföldkő): MrÁv 2007 (13/1, 2?, 3, 8-9, 29?. lh). 
A pannoniai vicusok területe mindenképpen jóval kisebb, mint a nyugati provinciákban. A Rajna mentén pl. Wieslochban egy 15-20 km átmérőjü territorium központjában feküdt a vicus. ${ }^{37}$ Ehhez képest a pagus Herculius vicusai a $6 \mathrm{~km}$ átmérőjü átlag területtel jelentősen kisebbek. A vicus Vindonianus területét Alföldy Géza kb. $40 \mathrm{~km}^{2}$-ben határozza meg. Ezen belül 3-4 $\mathrm{km}^{2}$ lehetett a municipális középbirtokok nagysága, a többi pedig a szabad kisparaszti birtok, amit a vicani műveltek. Itt a békásmegyeri felirat alapján a 3. században nyolc birtokos (possessores) és a vicani éltek. ${ }^{38}$ Valószínüleg ide tartoztak a budakalászi villák is, Pomázon pedig már egy újabb vicus kezdődhetett, ahol a 2. században a Dera-patak két partján egymáshoz közel öt villagazdaság is található egy kb. $1,5 \mathrm{~km}^{2}$-es területen. Itt futhatott esetleg egy limesútból leágazó kisebb út is, amely Pomázon át a szentendrei táborhoz vezetett. ${ }^{39}$ Nagyobb felületű ásatás hiányában nem dönthető el, hogy különálló villagazdaságokról, vagy esetleg egy összefüggő, nagyobb vicus központról van itt szó. ${ }^{40}$ A feltárt civil vicusok kiterjedése nemigen vethető össze a katonai vicusok méreteivel. Ez utóbbiak több oldalról körbevették a tábort és az utak mentén helyezkedtek el. ${ }^{41}$ Ezzel szemben a jelenleg tárgyalt vicusok mindig patakparton, azzal párhuzamosan kb. 200-250 méter szélességben, hosszan elnyúló települések.

A fentiek alapján megállapíthatjuk, hogy a vicusok és a környezetükben lévő villák, telepek kapcsolatára többféle megoldás is létezik. Van, ahol a vicusok területe nagy valószínűséggel magába foglalta a környező villagazdaságokat is. Ilyen lehetett pl. Pátyon, ahol a vicus központi része körül legalább két villagazdaság és több kisebb telep nyomai mutathatók ki. Budaörsön viszont jelenleg nincs tudomásunk más nagyobb villaépületről a már feltárt területen kívül. Itt, a sok kőépületet alapul véve a birtoktulajdonosok a vicus központjában építhettek házat. De az is elképzelhető, hogy a vicus több, a patakparton hosszan elnyúló, elszórtan elhelyezkedő villagazdaságok láncolata, ld. Dera patak vagy Benta patak völgye. Intercisa környékén a „vicus Caramantesium et villa” kifejezés felveti a lehetőséget, hogy a vicus egy nagyobb villaközpont körül létrejött falu volt. Máshol is megfigyelhetők kisebb falvak a villagazdaságok között, de nem biztos, hogy ezeket is vicusnak nevezhetjük. A vicus és villa kapcsolata tehát még korántsem tisztázott probléma. ${ }^{42}$

\section{Periodizáció}

A vicusok közül némelyik kelta telep folytatásaként jött létre, de sokat a rómaiak alapítottak, az oppidumok illetve a limes menti sáv kiürítésekor.

\section{Kelta elözmények}

Kelta előzmény mind a három, jelenleg tárgyalt vicusnál kimutatható. Budaörsön, a Kr.e. 1. század 2. felétől bizonyítható az élet a kerámiaanyag és érmek alapján. Az Augustus-kori sigillaták a foglalás előtti szövetségi viszonyt jelzik a Római Birodalom és a helyi kelta vezetők között. ${ }^{43}$ A pátyi eraviscus telep kezdete az Augustus-kor. A kelta érem, a festett sávos kerámia, a 
borostyángyöngyök és üvegkarperecek élénk kereskedelmi kapcsolatot tételeznek fel a Gellérthegyi oppidummal. ${ }^{44}$ Biatorbágyon is van ugyan késő kelta grafitos kerámia, de kétséges, hogy a római kor előtti vagy csak egy római foglalás utáni bennszülött telepről van szó. ${ }^{45}$

\section{Flavius-kor}

Aquincum környékén a katonaság megjelenésével, legkésőbb a Flavius-korban változtak meg a településviszonyok, számolták fel az őslakosság korábbi telepeit és hozták létre a határvonal mögött a római jellegü vicusokat. Mindhárom telepen az 1. század második felében, a Flavius-korban indul be nagyobb mértékben a római import és a folyamatos pénzforgalom. Budaörsön az objektumszám háromszorosára nőtt a kelta telephez képest $(210 \mathrm{obj}) .{ }^{46} \mathrm{~A}$ lakosság földbe mélyített házakban élt (objektumok 25\%-a). Ezek, az elsősorban téglalap és ovális alakú, néha négyzet és kör alakú házak a 2. század végéig továbbélnek, bár a forma és a cölöpök elrendezése periódusonként változott (Fig. 5-6). ${ }^{47}$ A gazdagabb házakat kőalapozású vályogfalakkal erősítik meg, félig, vagy teljesen körbevéve őket (Fig. 9.4).

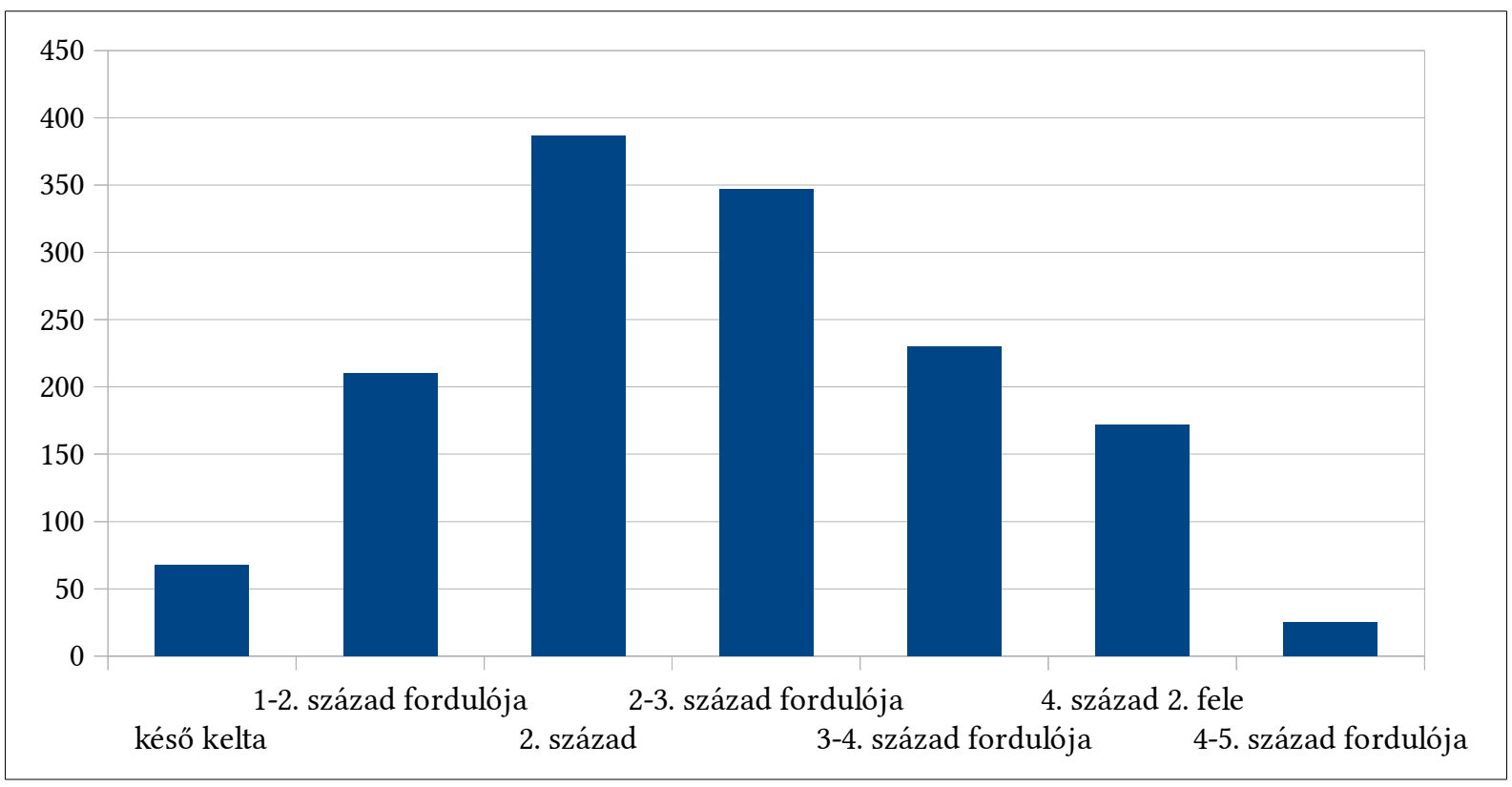

A budaörsi vicus objektumainak mennyiségi megoszlása az egyes periódusokban

A telep lakosságának alapvető részét ebben az időszakban a bennszülött kelta népesség alkotta. A romanizáció kezdetét jelzi, hogy átvéve a sírkőállítás szokását, néhányuk nevét már ismerjük is a másodlagosan beépített feliratokról, pl. egy asztrális szimbólummal díszített sírkövön Veriuga, Suadutio leánya, egy síroltáron Nonnus, Busaius fia szerepel (Fig. 7.1-2). A kelta eredetű, de már romanizált lakosság két tagjának névtöredéke maradt fent edények oldalfalába bekarcolva: /SA/BINUS, egy S-profilú, szürke tálon és FELIX, a Resatus névbélyeges tál külső oldalán (Fig. 7. 5). ${ }^{48}$ Ez utóbbi ember egy félig kőfallal körbevett házban lakott.

folytatódtak az 1. század közepén, második felében is. A késő kelta telep lakóinak száma a feltárt lakóházak alapján öt főt számolva házanként - 100 fő körül lehetett (mủhelyekkel együtt 21 ház). Összesen 68 objektum került elő.

44 OtTOMÁNyi 2007a, 124-140; TORBÁgyi 2007.

45 MRT 7, 346 (36/19. lh); Mráv 2010, 148.

46 A lakosság száma a lakóházak alapján (földbe mélyített ház, a mủhelyekkel együtt 53, felszíni ház kb. 4 db, félig kőfalas épület $5 \mathrm{db}$ ), megközelítőleg 200-310 fő lehetett (ОттомÁNyı 2012a, 298-301).

47 Budai BALOGH 2009; OtTomÁnyi 2012a, 103-154; OttomÁnyi $2014 \mathrm{~b}$.

48 Mráv 2014, 109-110. 
A lakosság másik rétegét a leszerelt katonák, a veteránok alkották. Az 1-2. század fordulójára keltezhető periódusból több díszes kivitelü, nielló berakásos bronzveret, illetve egyéb katonai tárgy (pl. sarkantyú, vaslándzsa, vaszabla) köthető hozzájuk. A lószerszámok auxiliáris lovaskatonák, a fegyverövek (cingulum) gyalogos katonák tulajdonában lehettek, amelyeket leszereléskor megőriztek és hazavittek későbbi lakóhelyükre (Fig. 7.6, 8). ${ }^{49}$ Ugyanilyen korú lószerszám garnitúrához tartozó phalera csüngő a biatorbágyi vicusból is előkerült, felvetve ezzel a Flavius-kori veterántelepítés lehetőségét (Fig. 7.7). ${ }^{50} \mathrm{Nem}$ minden esetben a helyi, bennszülött származású katonák tértek vissza a leszereléskor a családjukhoz. A Flavius-korban messzebbről besorozott és Aquincumban (Albertfalván) szolgált ala katonák is letelepedhettek a szolgálati helyükhöz közel eső vicusban. A veteránok ugyanolyan földbe mélyített házakban laktak mint a bennszülött lakosság, de a szokásos kelta jellegű kerámia mellett itt jelennek meg legkorábban a római import áruk.

A lakosság idegen eredetű, romanizált rétegéhez tartozott a már három nevet viselő római polgár, Titus Sulpicius Iustus, aki még feltüntette egy nevet viselő apját sírkövén (Magni filius). Neve alapján nem helyi származású, Itáliából, Galliából vagy Hispániából érkezett (Fig. 7.4). ${ }^{51}$

Ugyanez a lakosság összetétel Pátyon is megfigyelhető. A temetőben négy sírkőről - filiatióval együtt - 12 kelta név maradt ránk, többségük nő vagy fiatalabb fiú. A felnőtt férfiak nem őrizték olyan sokáig kelta nevüket (Fig. 7.3). A vicus lakóinak másik rétegéhez a veteránokhoz köthető, az M1 autópálya mellett szórványként előkerült Traianus-kori katonai diploma töredék. A Domitianus alatt besorozott bennszülött ifjú, már mint római polgár tért vissza szülőfalujába leszerelésekor. ${ }^{52}$

A feliratos emlékeken túl a leletanyag (kerámia és ékszerek) utal még a lakosság összetételére. A bennszülött nők két vállon viselt szárnyas és egygombos, erősprofilú fibulái mellett (Fig. 8.1-3) idegen eredetű elemekhez köthetők egyes ékszerek pl. az itáliai gyártmányú alesiai típusú fibula, vagy a Rajna-vidéken ill. Raetiában kedvelt szemes fibulák illetve a galliai csuklós szárnyas fibula (Fig. 8.4-6). ${ }^{53}$

\section{Hadrianus-Antoninus-kor}

Aquincum municipiummá válása Kr. u. 124-ben a környező telepek életében is döntő változásokat hozott. Most szervezték meg a municipium territoriumán a pagusokat, és jött létre a feliraton is említett pagus Herculius, amelynek vezető vicusa Budaörs lett. Ebben a markomann háborúkig tartó időszakban mindhárom vicusban megindul a kőépítkezés. Budaörsön a telep leggazdagabb része és központja a nyugati felén lévő félköríves épületsor, amelynek építése a Hadrianus-korban kezdődhetett, majd az Antoninus-korban a több helyiséges, közép- és oldalfolyosóval rendelkező nagy lakóépületek közé kis, szögletes, gazdasági jellegű melléképületek kerültek (Fig. 9.1-2; Fig. 10.2-3). A korszak kedvelt épülettípusa a téglalap alakú, egyharmadnál osztott forma, amelyet később hosszában is kettéosztottak. Ezek többszöri átépítéssel fennálltak a 4. század végéig (Fig. 10.4). A patakparti sávban díszes, freskós, terrazzopadlós épületek maradványai kerültek elő és egy apszisos épületrészlet is megmaradt (Fig. 9.3). ${ }^{54}$

49 MRÁv 2012.

50 MRÁv 2010.

51 A feliratok olvasatát Mráv Zsoltnak köszönöm (Mráv 2014, 100-103)

52 Mráv 2007, 403-408, 414-417, 420 (Bennszülött, teljes nevek: Limarus Cucalonis f., Magia Sicionis f., Masia Cauronis f., Camiio Masaconis f.). A katonai diploma az M1 autópálya 22-es kilométerénél került elő, tehát minden bizonnyal a Malom-dülőben feltárt vicushoz tartozott.

53 Oтtományi 2007a, 156, 114. kép 2, 125. kép 2; Merczi 2012, 4, 6, 8, 10. típusok.

54 A korszak 387 objektumából földbe mélyített ház 68 db, felszíni cölöpház $11 \mathrm{db}$. Kőépület 40 db, amelynek fele a Hadrianuskorban épült (ОттомÁNYi 2012a, 311-316). 
A pátyi telepen is hasonló fejlődést figyelhetünk meg. A földbe mélyített házak egyik csoportja majdnem szögletes, az ÉK-i sarokban kemencével (Fig. 11.1). A lakóházak másik típusa felszíni cölöpház, felmenő sövény- vagy gerendafallal (Fig. 11.2). A kőépítkezés itt is a Hadrianus-korban kezdődött, egyszerű, négyszögletes vagy téglalap alakú, többnyire osztatlan épületekkel (Fig. 11.3). ${ }^{55}$ Biatorbágyon is van egy markomann háborúkat megelőző periódusa a kőépítkezésnek, ahol a kőépület falai mintegy 45 fokban eltérnek a későbbi épületek tájolásától. ${ }^{56}$ A $164-$ 180 között folyó markomann háborúk során leégett a telepek nagy része. Az égésrétegek több helyen is megfigyelhetők a pátyi és budaörsi vicusban.

A telepek lakosságát a 2. században továbbra is alapvetően a helyi bennszülöttek alkották. A tömeges polgárjogadás Hadrianusszal kezdődött meg az eraviscus területen. A helyi arisztokrácia ebben az időben tett szert nagyobb befolyásra, gazdagságra, ez egyrészt a helyi közösség vezetésében nyilvánult meg, másrészt a katonai elitalakulatokban (lovasság) szolgáló fiaik segítségével családjuk polgárjogot is szerzett. A budaörsi temetőben előkerült négy bolygatatlan kocsi sír is ehhez a bennszülött arisztokráciához köthető. Közülük az egyikben auxiliáris katonához tartozó fegyverek is megmaradtak. E sírok valószínúleg egy kiemelkedően gazdag, a vicus vezetésében szerepet játszó bennszülött család több generációjának a temetkezései a 2. század első felében és közepén. Esetleg a vicusnak nevet adó Teuto személynév is e családhoz tartozott. ${ }^{57}$

Páty bennszülött vezetőrétegéhez - a nők által viselt fibulákon túl - a 2. század közepén mindössze egyetlen, Rómer által lerajzolt és azóta elveszett kocsi jelenetes sírkő köthető, amely a Füzes-patak másik oldalán (Páty, Lövöldöző, 13/1. lh.) került elő. Rajta négykerekű kocsi ábrázolás, két lóval. ${ }^{58}$ Közelében egy auxiliáris katona fegyveres, lovas sírját tárták fel 2004-ben. ${ }^{59}$

Az eraviscus női viseletre jellemző fibulák alapján következtetni lehet az egyes építmények bennszülött tulajdonosaira. Így pl. Budaörsön a középfolyosós épület első periódusában a tulajdonos felesége még őrizte a kelta viselet hagyományait és szárnyas fibulával tűzte meg két vállán ruháját. Egy másik budaörsi kőépület tulajdonosának felesége egygombos, erősprofilú fibulát viselt. A lakosság idegen eredetű rétegéhez köthetők, a Rajna-vidékről származó un. emailos fibulák, amiből több szórvány darab is előkerült a pátyi telepen (Fig. 8.8). ${ }^{60}$

\section{Severus-kor}

A markomann háborút követő újjáépítés, a Severus-kori virágzás ideje a dunai limes körzetében. A pontosabb keltezést elősegítő sigillata anyag legnagyobb része erre az időszakra tehető, ami jelzi a lakosság összetételében és gazdagságában bekövetkezett változást (Fig. 16.3). Ugyanerre mutat a lakóházak jellegének átalakulása is. A földbe mélyített házakat felváltják a felszíni, cölöpszerkezetes házak ill. kőépületek. A 2. században megjelenő cölöpszerkezetes agyag- vagy gerendafalú házak a század vége felé egyre gyakoribbak lesznek. Méretük és formájuk változatos, a kisebb, egyosztatú gazdasági épületektől kezdve a nagyobb, többosztatú lakóházakig mindenféle típusuk előfordul. Teljes körvonalukat gyakran nem ismerjük, mert ráépültek a későbbi kőépületek, például Pátyon a H kőépület alatt rajzolódik ki több ilyen cölöpszerkezetes épület (Fig. 13.1). ${ }^{61}$

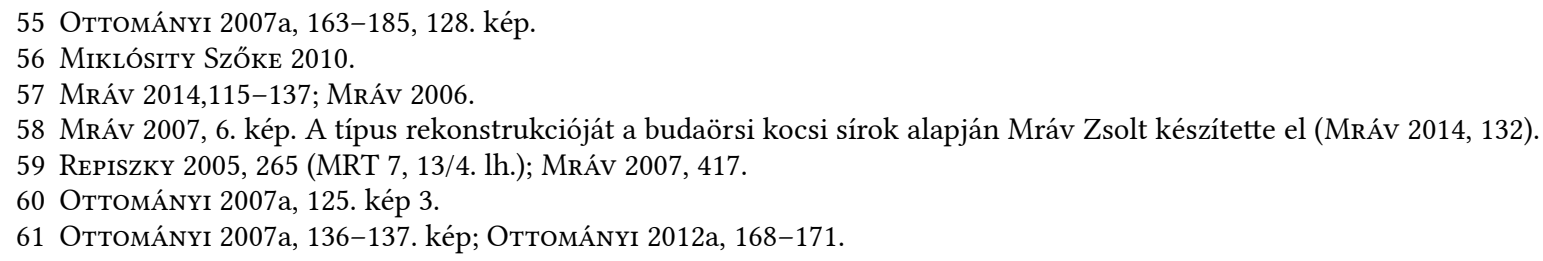


Pátyon, a feltárt részen körülbelül 30 helyen figyeltünk meg Severus-kori kőépítkezést. Vannak köztük kis, szögletes, gazdasági épületek, több közepes nagyságú és két nagy, 400-500 m2-es kőépület is (Fig. 12.1-3; Fig. 13.2). ${ }^{62}$ A Severus-korban épült Pátyon, a feltárt terület északi felén egy kelet-nyugati irányú „kerítésfal”, amit kb. 40 méter hosszan követtünk, majd befordult dél felé. A fal északi oldalán egy szakaszon utcaszerű kikövezés található, viszonylag lapos, de apró kövekből (Fig. 22.2). Ebbe a kerítésfalba futott bele a kövezett út, ami valószínűleg továbbment a temető felé, körülbelül 70 méter hosszan látszott a humuszolás után (mindkét végét elvitték a gépek). Szélessége 3-4 méter (Fig. 12.4). Az út felszínén talált terra sigillata chiara bizonyítja, hogy a telep életének végéig használatban volt. ${ }^{63}$

Budaörsön 90 kőépület maradvány köthető ehhez a 2. század utolsó negyedétől a 3. század közepéig terjedő időszakhoz. Ez volt a kőépítkezés virágkora (Fig. 14.1). ${ }^{64}$ Majdnem felük elszántott épület, falmaradvány, kőomladék. Ebben az időszakban már megtalálható szinte valamennyi típusa a kőépületeknek (Fig. 10.1). A korábbi épületeket általában megújították, átépítették. A gazdagabbak igyekeztek a telep központjában, a patakhoz közeli részen házat építeni, mégha ez egy korábbi épület bontásával, átépítésével is járt együtt. Területileg ez a központi rész nem bővül a 2-4. században, inkább egymásra rétegződnek a periódusok. Látszik, hogy a félköríves házsor még mindig a település központja, bár a széleken is egyre több ház tűnik fel. Az épületsor belsejében lévő sóderes téren talán már ekkor itt állt egy kis oszlopos, szögletes szentély. Az épületek egyre díszesebbek lesznek. Fűtőcsatornák, a padlófütés hypocaustum oszlopai, stukkó és freskó maradványok, padlótéglák, világításra szolgáló agyag modellek jelzik a kiteljesedő romanizációt (Fig. 15). ${ }^{65}$

A kőépületekben a szomszédos Aquincum városi tisztségviselői és a hadseregben szolgált, leszerelt veteránok családjai éltek. A korszak jellemzője a „katonafibulának” nevezett térdfibula, valószínüleg a civil férfiak is hordták már a 2-3. század fordulóján ${ }^{66}$ (Fig. 16.1). Nyugati eredetű tulajdonosokra is következtethetünk az ékszerekből (lásd korongfibula a középfolyosós épületből) ${ }^{67}$ és a jóval ritkább, felső-germaniai-raetiai limes mellől idekerült villás kengyelü fibula (Fig. 8.7,9). Ez mutatja, hogy gyakran a korábbi bennszülött vezetők kezében lévő házak tulajdonost cseréltek. A gazdagabbak nevét feliratos oltárkövek, sírkövek, egy szarkofág és két határkő őrizte meg számunkra. Aquincum vezető tisztségviselője, duumvir és pontifex volt M. Antonius Victorinus, aki Budaörsön több oltárt is állított, egyiket feleségével együtt (Fig. 16.4-5). A Severus-korban a vicus lakosságának másik jelentős és tehetősebb rétegét az Aquincumban ill. Campona táborában állomásozó legio II adiutrix ${ }^{68}$ és az ala I Thracum katonái ${ }^{69}$ és azok családtagjai alkották. A 210-es években élt itt például Aurelius Firmanus családjával. Ỏ temette Lauriacumban elhunyt apját, aki a legio II adiutrix sasjelvényének hordozója (aquilifer) volt, a temetőben talált szarkofágba (Fig.16. 11). ${ }^{70}$

Pátyon egy lovas katona (Crispinianus) sírköve illetve a legio II adiutrix egyik katonájának (Longinianus) oltárköve utal a birtokkal rendelkező lakosság katona rétegére, de egyik sem jelenleg ismertetett telepről származik (Fig. 16.9). A városi arisztokráciát M. Valerius Karus,

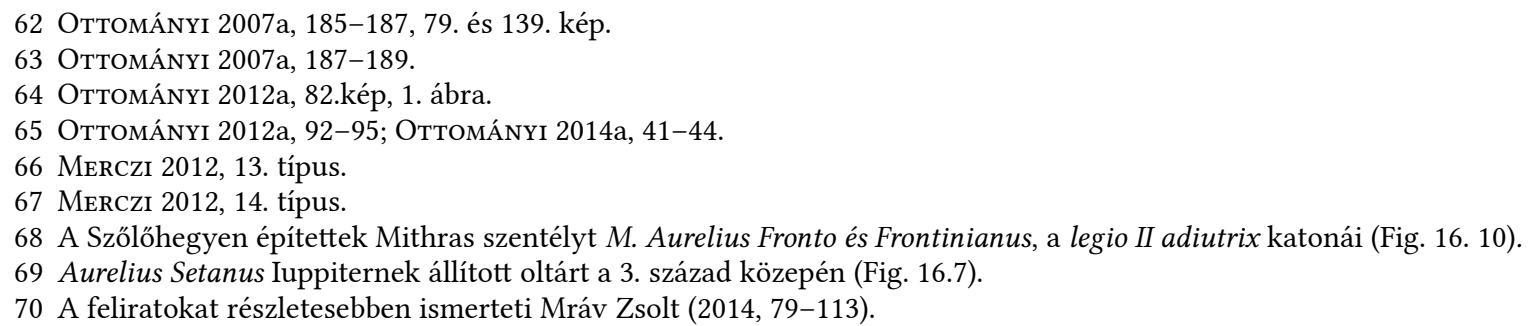


aquincumi duumvir Nympháknak állított oltárköve képviseli, ami a forrásszentélynél került elő (Fig. 16.6). További töredékes feliratokról még öt civil lakos nevét illetve névrészletét ismerjük. ${ }^{71}$

A korszak végét Budaörsön és Biatorbágyon elrejtett éremleletek jelzik. A kincsek tulajdonosai már nem tudták kiásni elrejtett pénzüket, elpusztultak a telep nagy részével együtt. A budaörsi 2236 darabos ezüst éremkincs Kr. u. 251/253-as években, a biatorbágyi kicsit később, a Kr.u. 259-260. telén zárul (Fig. 17.5). ${ }^{72}$ Mindkét települést a szomszédos barbár (szarmata - kvád) betörések pusztították el, aminek nyomait elrejtett éremkincsek sora jelzi a limes mentén.

Biatorbágyon a feltárás során körülbelül 50 fal, falkiszedés, alapozásnyom illetve agyagtégla fal volt megfigyelhető. A 2. század végi kőépületek ráépültek a kora római objektumokra, így biztos, hogy a markomann háborúk után itt is népességváltás következett be. A feltárt épületegyüttes egy központi, hét helyiséges lakóépületből, több kisebb gazdasági épületből és kerítésfal részletekből állt. A fóépület két helyiségét fütötték és több helyen freskó és stukkó maradványok kerültek elő (Fig. 17.1-4). Bejáratánál porticus lehetett. A feltárt terület környezetében még nagyszámú építészeti emlék és épületnyom ismert. Egy oltárkő és oszlopfő szentélyre enged következtetni. Egy helyen sikerült megfogni egy szegélykövekkel ellátott kövezett útrészletet is a kerítésfal bejáratánál. A kiszedett falakon 4. századi kavicsos járószinteket találtak. A telep ugyanis újjáépült a 3. századi pusztulás után és az éremforgalom alapján a 4. század végéig fennállt. A pusztulás idejéhez köthető több gödörbe temetett csontváz. ${ }^{73}$

\section{Késố római kor (3. század 2. fele - 4. század)}

A barbár támadás után a telepek csak lassan, a 3. század utolsó negyedében/végén kezdtek újjáépülni. (Aquincum ekkor, 294-ben lett Valeria provincia katonai vezetőjének, a duxnak a székhelye). Innentől a vicusok élete a 4. század utolsó harmadáig folyamatosnak tekinthető, helyenként még az 5. század elejéig is kimutatható. Az érmek alapján virágzott az élet még a század második felében, utolsó negyedében is, miután a limes menti városokból a lakosság egy része a vidéki birtokokra húzódott, távolabb a veszélyeztetett limes szakasztól.

Budaörsön a telep szerkezete a 3. században megváltozik. Ekkor épül ugyanis az egészet középen kettéosztó, észak-déli irányú kövezett út és vele párhuzamosan kerítésfalak, kőépületek, felszíni házak, stb. ${ }^{74}$ (Fig. 14.2). Három kövezett út maradt meg, mindhárom a késő római telep központjában, egymással összekapcsolódva. Nem mindig derékszögben találkoznak, tehát nem egyszerre épültek, de volt olyan periódus, amikor mindet egyszerre használták. Ezt bizonyítja a kőpilléreken nyugvó kapu, ami a két nagyobb út kereszteződésében állt (Fig. 18.5). Az útalapozás kisebb-nagyobb kövekből készült, felszínükön sóderes járószint lehetett. Szélüket egyenes sorba rakott, nagyobb kövek jelzik. Szélességük 4-6 méter között mozog, ami megközelíti egy belső-pannoniai út szélességét. A telepről kifutó szakasz nem maradt meg, pedig minden bizonnyal összekapcsolódott az Aquincumba vezető egyik, fő, kereskedelmi útvonallal.

71 Mráv 2007, 410-413, 418-420: Septimius Viator, Ulpius Valentinus, Victor, Candidus, Faustus. (MRT 7, 13/1., 3., 9?, 29. lelőhely).

72 KABA 1983-1984; ReDő 2012.

73 MiкLósity SzŐKe 2010.

74 A késő római korhoz 326 objektum köthető. A lakóházak többsége már a Severus-kortól kezdve kőépület, a 4. századra pedig a lakosság szinte teljesen behúzódott a kőfalak védelmébe. Földbe mélyített építményeket már csak műhelyként, raktárként használtak. E periódus kőépületeiből csak néhánynak ismerjük az alaprajzát, általában szétszántott falmaradványok őrződtek meg (62 épület). A kövezett utak pontos építési ideje kérdéses, a felszínükön lévő Severuskori sigillata némelyiknél korábbi keltezést is lehetővé tesz. Valamennyit használták a 4. században. Részletesebben lásd OттомÁNYi 2012a, 353-368, 262. kép. 
A késő római telep főépülete a kövezett utak kereszteződésében épült. Sóderes járda, illetve terrazzós előtér kapcsolta össze velük. A 3. század második felében épült nagyméretű, álló téglalap alakú, egyharmadnál osztott, díszes kivitelü épület belső terét több oszlop tagolta és porticusos bejárattal fordult az út felé. A 4. század folyamán átépítik, kibővítik (Fig. 18. 1-4, 6). ${ }^{75}$ Mérete, kivitele és helyzete reprezentatív középületre utal, aminek bővítményei a 4 . század vége felé már az egész közösség terményeinek tárolására, feldolgozására szolgáltak. A nyugati félköríves épületsor nagyobb épületeit még használták - az érmek tanúsága szerint a 4. század utolsó harmadáig. ${ }^{76}$ Átépítik, kisebb helyiségekre osztják őket. Ebben a késői időszakban gyakori, hogy több család lakik az egykor osztatlan nagy épületekben. A patakparti épületekben is laktak még, bár az egyik, freskós ház fölé már sóderes út került. A telep északi szélén két, fekvő téglalap alakú, kelet-nyugati tájolású épület zárja le a kőépületes sávot. Köztük keskeny folyosó vagy utca. Ennek világítását egykor az épület falait díszítő agyagkapu modellel oldották meg (Fig. 15.6). Mérete alapján talán ez is középületként funkcionált. ${ }^{77}$

A vezetőréteg tagjainak (hivatalnokok, katonai vezetők, gazdagabb földbirtokosok) lakóhelyeit jelzik a hagymafejes fibulák és az import terra sigillata chiarák (Fig. 19.5). ${ }^{78}$ A kőépítkezés legutolsó periódusa az érmek alapján a Valentinianus-kor (Fig. 19.1). Ekkor még virágzott a település. Ezeket az érmeket a század végéig biztosan használták, de új pénz hiányában valószínűleg még az 5. század elején is forgalomban voltak. A telep legkésőbbi érme egy 5. század eleji kisbronz, ami a fóépület legutolsó hozzáépítéséből került elő.

Az épületekben és gödrökben lévő köves, téglás, égett pusztulási omladékot a leletanyag többnyire a 4. század végére, néha viszont ennél későbbre, az 5. század elejére keltezi (lásd besimított díszítésű edények; Fig. 19.8). A telep élete tehát kisebb területre összeszorulva, kisebb létszámban, de a 430-as évekig folytatódott (körülbelül 25 objektum). Ezek a rétegtanilag legkésőbbi objektumok (épületekbe ásott gödrök, cölöpvázas építmények, gödrökbe temetett csontvázak) már egy kevert, továbbélő római és újonnan betelepülő barbár lakosság hagyatékának tekinthetők (Fig. 19.2-4, 6). ${ }^{79}$

Pátyon a talajművelés elpusztította a felső rétegeket és csak szétszántott kőomladékokat hagyott meg. Ezek alapján sejthetjük, hol voltak késő római épületek, de összefüggő alaprajzokat már nehéz kimutatni. Formához köthető 12 épület és a rétegtan alapján még körülbelül 20 kőépület maradványa tehető erre a periódusra. A két nagy, Severus-korban épült kőépület mindegyikében volt későbbi periódus. Ekkor kövezték le a belső udvarokat és az egyiknek a konyhájában kőboltozatos téglakemence is épült (Fig. 11.6-7; Fig. 15.4). Néhány 4. század végi - 5. század eleji lelet (csontfésű, cikádafibula töredék) az épületek közé betelepülő, a rómaiakkal együtt élő barbár népcsoportok jelenlétét bizonyítja. Etnikumuk kevert. ${ }^{80} \mathrm{~A}$ telep déli végénél, a mai Biatorbágy területén földbe mélyített házak és gödrök is köthetők ehhez az 5. század eleji népességhez. A telep pusztulását jelző, gödörbe temetett/dobált csontvázak mellett polyéder végződésü fülbevalók és csontfésűk is előkerültek (Fig. 19. 7). A teleprészlet kora a hun korszakba is belenyúlhat, hiszen ebből az időből több temetkezés is ismert a vicus környékéről. ${ }^{81}$

75 A keleti bővítmény két helyiségét nagy kőlapokkal burkolják, egyikben kőmozsár állt. Gazdasági, konyhai funkciót is betöltő belső udvarok lehettek. Alapterülete körülbelül 700 m2, 18 helyiségre oszlik (OTтомÁNYi 2012a, 30-38, 19-25. kép).

76 A középfolyosós épületben 324 után épül meg a legfelső habarcsos padló és a felmenő vakolt falak. Az épület délkeleti sarka újabb helyiséggel bővül és terrazzo padló kerül két korábbi fal fölé. Legtöbb helyiségében ablaküveget használtak és az ajtónyílások küszöbkövei is ránk maradtak (Fig. 15.1). A nyugati szárnyban kisebb szobákat alakítanak ki, valószínủleg a 4. század második felében (ОттомÁNyi 2012a, 14-23, 4-5. kép).

77 OтTOMÁNYi 2012a, 56, 42. kép.

78 OtTOMANYi 2012a, 269. kép.

79 OTTOMÁNYi 2009; OtTOMÁNYi 2012a, 367-372.

80 OtTomÁnyi 2001; OtTományi 2007a, 193-205.

81 OtTomÁNyi 2008. 


\section{A vicusok jellemzői, szerkezete}

A katonai vicusok állandó elemei a lakó és gazdasági épületeken túl a szentélyek, fürdők, mansio, curia, talán forum. ${ }^{82}$ Mindezek közül általában lakó- és gazdasági épületek fordulnak elő a feltárásokon. Budaörsön egy épület tartható középületnek, szentélyek meglétére pedig elsősorban az oltárkövek utalnak mindhárom telepen.

Egyértelmű, hogy a padlófütéssel és terrazzopadlóval ellátott épületek lakás céljaira szolgáltak. Ugyanakkor nagyon sok esetben laktak az egyszerübb kivitelü, agyagpadlós, felmenő agyagfalú (kőalapozású), padlófütéssel nem rendelkező épületekben is. Leginkább a többosztatú épületeket sorolhatjuk ide, az egyhelyiséges, osztatlan kőépületek inkább gazdasági funkciót töltöttek be. Az is gyakori, hogy az épület egyes helyiségeiben laktak, a többi műhelyként, raktárként funkcionált (ld. a középfolyosós vagy a kétharmad résznél osztott típus). ${ }^{83}$

A katonai vicusoknak rendelkeznie kellett tanácskozó hellyel, curiával és esetleg a canabaeban előforduló forummal is. Bár csak szórványos adatok vannak arra, hogy ilyen hivatalnoki testületet (magister, decurio, curialis) feltételezhetünk egy vidéki, civil vicusban is, de a vicus közös ügyeit (például oltárállítás, bíráskodás stb.) intézni kellett valahol, így hát középületre itt is szükség volt. Elsősorban Budaörsön, ahonnan esetleg a pagus irányítása is történt. ${ }^{84}$

Budaörsön egyetlen egy nagy épület tölthetett be közéleti funkciót. ${ }^{85}$ Ez pedig a három oldalról kövezett úttal körülvett, 3-4. századi fóépület (L/263. obj.). Volt kövezett udvara, freskós, oszlopos nagy helyisége, porticusos bejárata, majd később a déli út felé nyitott, pilléres, terrazzós nagy szabad tere. Ez utóbbi piactér funkciót is betöltő forum része is lehetett. A kora római településen, a nyugati épületsor egyik épületében található tanácskozóteremként használható nagyobb, freskóval díszített helyiség (Fig. 10.3), terrazzopadló viszont nem maradt ránk. Ezen időszak bennszülött származású vezetői még nem emelkedtek ki olyan gazdagon felszerelt és díszített házakkal a többiek közül, mint a 3. században. Esetleg a vicus irányítása is még Aquincumból történt, és nem volt szükség középületre. Forumként, piactérként szolgálhatott a 2-3. században a nyugati félköríves házsor sóderes felületű belső tere, például Arrabona vicusának központjában van ilyen tér a Hadrianus-kortól. ${ }^{86}$ A Birodalom nyugati részén, a germaniai és raetiai katonai vicusokban is megfigyeltek hasonló tereket, amelyeket Sommer piactérnek határozott meg. ${ }^{87}$

Vidéki telepeken, vicusokban, villákban szentélyeket ritkán lehet beazonosítani.Az oltárkövek többnyire másodlagosan beépítve, illetve egy-egy árok vagy gödör későbbi feltöltéséből kerülnek elő. Budaörsön több istennek is állítottak oltárkövet, tehát valahol a vicusban szentélyük is állhatott. ${ }^{88}$ Mint a pagus Herculius vezető vicusának, hivatalból is kellett, hogy legyen szentélye a főistennek, Iuppiternek, továbbá a pagusnak nevet adó Herculesnek. Iuppiternek Aurelius Setanus lovaskatona állított oltárt, Herculesnek pedig M. Antonius Victorinus, Aquincum colonia duumvirje. Ugyanő, feleségével együtt Terra Maternek is szentelt oltárt (Fig. 16. 4, 7; Fig. 1. 1-2). A vicus és pagus nevét megőrző oltárkő alapján a Terra

82 KovÁcs 1999, 153-156.

83 Bíró 1974, Fig.11-12; Otтományi 2012a, 89-96.

84 KovÁcs 1999, 118; Összefoglalóan irodalommal együtt: OттомÁNYi 2007a, 213; A pannoniai vicusok ill. pagusok vezető tisztségviselőinek fellépése eddig csak kultuszcselekmények esetében igazolt (MRÁv - OTTOMÁNYI 2005, 81-82).

85 OtTományi 2012a, 97.

86 Bíró 2009, 59.

87 SOMMER 2002, 444.

88 Otтományi 2012a, 96; MrÁv 2014, 79-95. 
Mater szentély is a budaörsi vicus központjában állt. Terra Mater mint az anyaföld megszemélyesítője, a földművelés patrónusa és az egész Római Birodalom földjének védő istennője, jelentős szerepet tölthetett be a vicus vallási életében. Szentélyépületet nem tudunk kötni ezekhez az oltárkövekhez. ${ }^{89}$ Budaörsön, nem a vicus feltárt részén, hanem távolabb, a Szőlőhegyen, egy Mithras-szentélyről is van tudomásunk, amelyet két testvér (M. Aur. Fronto és Frontinianus) alapított. Ugyaninnen egy Silvanus oltár töredéke is előkerült, így elképzelhető, hogy a magaslaton (a település szent hegyén?) több istenség kultuszát is ápolták (Fig. 16.8, 10). Budaörs és Budakeszi határán, a Csíki-erdőben 2009-ben került elő egy Libernek és Liberának szentelt oltárkő, amelyet a legio II adiutrix katonája (Aurelius Valens) állított. ${ }^{90}$ Környékén semmilyen épületmaradvány, szentély nem maradt meg. Lehetséges, hogy nem a vicushoz, hanem valamelyik budakeszi villához köthető.

Pátyon is kerültek elő oltárkövek, de nem a feltárt település területén. A főistennek, Iuppiternek szentelt, 1865-ből származó oltár közelebbi lelőhelye Pátyon belül nem ismert. A Nympháknak állított oltár a forrásszentélynél került elő (Fig. 3.1; Fig. 16.6). Két másik töredék, ahol az isten neve hiányzik, ugyancsak ismeretlen lelőhelyü. ${ }^{91}$ A biatorbágyi szentélyre utaló szórvány oltárkő felirata már nem olvasható. ${ }^{92}$

\section{A telep szerkezete ${ }^{93}$}

Mindhárom jelenleg ismertetett vicus patak mentén hosszan elnyúló település. Budaörs és Biatorbágy a Hosszúréti-patak, Páty pedig a Füzes-patak partján található. Hosszúságuk változó (több száz méter), ${ }^{94}$ szélességük körülbelül 250 méter. Házaik inkább a vízparthoz, nem pedig utakhoz lettek tájolva. Bár belső kövezett útrészlet mind a három telepen előkerült, de hozzá tájolt kőépületek csak Budaörsön voltak.

Budaörsön már a legkorábbi periódustól kezdve megfigyelhetők bizonyos szabályszerűségek a vicuson belül. Egyrészt elkülönül a telep sürübben lakott, kőépületes patakparti sávja, az északi, inkább tároló vermekkel, agyagnyerő gödrökkel, kemencékkel, műhelyekkel rendelkező „gazdasági, ipari” negyedtől. Házsorok, ha nem is az egész telepen, de annak déli felében már a telep 1. századi földbe mélyített házainál megtalálhatók (Fig. 20.1). ${ }^{95}$ Máshol kisebb házcsoportok alakulnak ki, körülöttük gödrök, gazdasági objektumok. Az ún. háztartási egységeken belül néha meg lehet figyelni, hogy a lakóházhoz más típusú gazdasági rendeltetésű objektum (felszíni cölöpszerkezetes terménytároló vagy kemencés műhely) csatlakozik.

A kőépítkezésen belül szabályosság a telep nyugati felében létrejövő félköríves házsornál figyelhető meg, már a 2. század első felétől. Ez a házsor a telep fennállásának végéig lakott, sőt keleti felében újabb házakkal bővül. Kérdés, mi lehetett a középső üres részen? Kereskedelmi forum, szentély vagy csak egyszerűen sóderrel borított tér? A 4. században már szemétgödröket ástak a korábban kavicsos felületű térbe.

89 Talán szentélynek tartható egy kis oszlopos, négyszögletes építmény, a félköríves épületsor belsejében (OTTOMÁNYI 2012a, 49. kép).

90 Borhy - BARTUS - Stibrányi 2013; MrÁv 2014, 85-92.

91 MrÁv 2007, 409-412.

92 Az oltárkő feliratát kitörölték, az ásató közlése szerint az első betű „I” volt, ami esetleg a IOM felirat részlete lehetett.

93 A feltárt területek nagysága már lehetővé teszi a telepek szerkezetének és objektumtípusainak összehasonlítását: Budaörs: 19 hektár, Páty: 9 hektár, Biatorbágy: 6,5 hektár. Részletesebben lásd OттомÁNY 2012a, 102, 144-150.

94 Pátyon a felszíni leletek alapján körülbelül 2 km hosszúságú a vicus beépített, központi része. Biatorbágyon a kora római település mintegy 800 méter hosszan kísérte a patakpartot. Budaörsön a feltárt terület hossza 460 méter, de sem keleti, sem nyugati irányban nem zárult le.

95 Oтtományi 2012a, 115. kép. 
A 3. században kiépülnek a kövezett utak, és a késő római telep fóépülete is szabályosan az észak-déli irányú fơút és a patakkal párhuzamos kövezett út kereszteződésébe épült. Mindkét út mellett további falak és épületek figyelhetők meg. Minden bizonnyal a település egyik leggazdagabb része a patakparti, mára már nagyrészt elpusztult sáv lehetett. Itt apszisos, freskós, terrazzós kőépületrészletek kerültek elő. A kövezett fóút egészen a patakig lefutott. A kőépületes részt északon egy hosszú kelet-nyugati irányú árok, illetve egy hasonló tájolású épületsor zárja le. Nyugaton egy oszlopos kerítésfal határolta az épületeket a kora római korban. Talán az egész telepet határoló kerítésfal vagy árok maradványaként értelmezhetők az északi rész kutatóárkaiban jelentkező üres, dupla árokrészletek, illetve a szélesebb, hoszszan elnyúló, köves, téglás törmelékrétegek. Belső tagolásra szolgáló kerítésfalak és rövidebb árokszakaszok is megfigyelhetők a telep belsejében (Fig. 21).

A gazdasági jellegű építmények a vicus északi szélén helyezkednek el. Ipari negyednek is nevezhetnénk, de nem teljesen egyértelmű a helyzet. Csak azt állapíthatjuk meg, hogy a település északi sávjában jóval több a gazdasági, mint a lakóobjektum. Ez a tendencia már az 12. századra is jellemző, de a késő római korban figyelhető meg leginkább (Fig. 20.2). Természetesen az északi részen is van néhány kőépület, illetve lakógödör, mint ahogy a déli részen is vannak bőségesen tároló vermek és egy-két kút is.

Összefoglalóan megállapíthatjuk, hogyha insulákba rendezett utcasorok nem is, de házsorok, házcsoportok, lakó és melléképület együttesek, egységes terv szerint kialakított kőépületek, kövezett útvonalak és ezekre tájolt lakóházak megtalálhatók a budaörsi vicusban, a telep életének mind a négy évszázadában. Védmúvek Budaörsön nincsenek, de ez a katonai vicusra sem jellemző. A vicusok egyik ismérve, hogy nem rendelkeznek a falak védelmével. ${ }^{96}$

Pátyon, miután a településnek jóval kisebb része lett feltárva és az sem összefüggően, a telep szerkezetéről jóval kevesebbet mondhatunk (Fig. 22.1). Budaörshöz hasonlóan a telep patakparti és a temető felőli széle lett lehatárolva, a másik két irányban, párhuzamosan a patakparttal még folytatódott. Itt annyival vagyunk jobb helyzetben, hogy a terepbejárás adatai kirajzolják a telep feltételezett hosszát. A kerítésfal úgy tűnik elválasztotta a telepet a temetőtől, de az északi oldalon a telep közepén fut, tehát csak egyes részeket kerített körbe (Fig. 22.2). Belső tagolásként kisebb kerítésfal részletek és árkok is megfigyelhetők. A telepen belül többféle út található, széles kövezett és keskenyebb sóderes útszakaszok egyaránt kerültek elő. A kövezett út Budaörshöz hasonlóan a dombtetőn lévő temetőtől futott lefelé a patakig, bár egyik helyen sem sikerült feltárni az egész hosszát. Itt is a patakpartot kísérik a nagyobb kőépületek, de van egy nagy épület a dombtetőhöz közel is. A feltárt területen a két nagyobb épület mellett körülbelül 30 helyen figyelhető meg kőépület nyoma. ${ }^{97}$ Tehát ez a telep sem sorolható az egy központi fóépülettel és azt körbevevő kisebb gazdasági épületekkel rendelkező villák sorába. Egyértelműen vicus volt, még ha feliratos bizonyíték nem is maradt fenn róla. ${ }^{98}$ Házsorokat is találunk, bár csak kisebb részletekben és itt is a telep szélét övezik a tároló vermek nyugaton.

Biatorbágyon a kora római bennszülött telep a másik két vicushoz hasonlóan a patakpartot kíséri több száz méter hosszan és körülbelül 250 m szélességben (Fig. 3. 2). A feltárt 2-3. századi

96 KovÁcs 1999, 156.

97 Körülbelül 65 fal, falkiszedés illetve kőomladék, amelyekből csak ritkán rajzolódik ki az épület körvonala (OTTOMÁNYı 2007a, 220-224, táblázat). A terepbejárás adatai alapján az eddig fel nem tárt területen még több, nagyobb kőépület is várható.

98 OттомÁnYi 2007a, 209. 
kőépítkezéses rész ugyanakkor nagyon hasonlít egy villagazdasághoz, amelyben egy fóépületet vesznek körbe a kisebb gazdasági épületek. A hét helyiséges központi épülettől északra körülbelül 200 méterre még egy nagyobb épület részlete, illetve körülbelül 500 méterre egy további kőépület nyomai rajzolódtak ki. ${ }^{99}$ A területen összesen körülbelül 50 fal, falkiszedés és alapozásnyom volt megfigyelhető, tehát mindenképpen nagyobb lehetett, mint egy villagazdaság. Talán itt nem a vicus központi részét, hanem az egyik hozzá tartozó villagazdaság épületeit sikerült feltárni. A szentély helye a településen belül ismeretlen, szórványként előkerült oltárkő és oszlopfő töredékek utalnak a meglétére. Kövezett útrészlet és kerítésfalak itt is megfigyelhetőek, azonban ennek a vicusnak a szerkezete alapvetően eltér a másik két ismertetett településtől. Az egész területet behálózó derékszögü kerítésfalak és árokrendszerek az ásató szerint a római kori centuriatio maradványai, tehát elképzelhető, hogy a település a Flavius-korban veterán telepítésként jött létre, ${ }^{100}$ esetleg egy korábbi kisebb, késő kelta telep helyén, vagy folytatásaként. A villaépület tájolásával megegyező árokrendszerek ugyanakkor szolgálhattak a vicus belső tagolására is.

Az egyes vicusok szerkezete nyilvánvalóan nem lehetett mindenütt egyforma. A kialakulás módja, a földrajzi körülmények, a vicus nagysága és funkciója is szerepet játszhat benne. ${ }^{101} \mathrm{~A}$ katonai tábor melletti vicusokhoz sem érdemes hasonlítani, mivel azok általában a táborból kivezető utakhoz tájolt, szabályos utcákat alkotó épületekből álló telepek. ${ }^{102}$ A civil, vidéki településektől, amelyek többnyire egy bennszülött faluból kifejlődve lettek római vicussá, nem várható el ilyen szabályosság. A fent ismertetett három vicus alapján azonban kijelenthetjük, hogy szabályszerüségek mind a földbe mélyített házaknál, mind a kőépítkezéseknél megfigyelhetőek, belső tagolásra szolgáló utak, kerítések, árkok e vidéki vicusokban is találhatók.

\section{Gazdasági élet: ${ }^{103}$}

Pannoniában a vidéki telepek, villák és vicusok funkciója elsősorban gazdasági jellegű volt. Fő megélhetési forrásuk a földművelés és állattenyésztés. Régészetileg a vasszerszámokon keresztül lehet leginkább a település gazdasági tevékenységére következtetni (Fig. 24.4, 6). ${ }^{104}$ Szántóföldi művelésre utalnak a sarlók és ösztökék. A szőlőmetsző és ágvágó kések, valamint kapa alapján szőlő- és gyümölcstermesztés is folyt a telepeken. A gabonatermesztéshez kapcsolódnak az őrlőkövek, amelyek földbe mélyített házakból, gödrökből és kőépületekből egyaránt előkerülnek. Ezek a már kelta lakosság által is használt kétrészes, forgatható kézi malmok használatban voltak egészen a késő római korig (Fig. 24.9). A háziipar meglétét az őrlőköveken túl szövőszéknehezékek, orsógombok és egyéb csont, kő illetve vasszerszámok bizonyítják (Fig. 24.7-8). A megőrölt gabonából a házak sarkában vagy a házak mellett lévő, szabadtéri sütő kemencékben készült a kenyér. Néha csak az átégett paticsfolt mutatja e kemencék helyét, ritka a jól megépített kőkemence. Koruk az 1-4. századig terjed, hiszen kenyeret sütni mindig kellett (Fig. 23.4, 7-8). ${ }^{105}$

\footnotetext{
99 Az ásató, Miklósity Szőke Mihály szíves szóbeli közlése.

100 MikLósity Szőke 2009, 152; MikLósity SzőKE 2012, 223.

101 Például a noricumi Flavia Solva környékén lévő két vicus közül Gleisdorf tipikus út menti település (Strassensiedlung), az út két oldalán fekvő és úthoz tájolt házsorokkal. A másik vicus (Kalsdorf) pedig inkább városias elrendezést mutató, parcellázott, egyik oldalán kerítésfallal és úttal határolt település (LOHNER 1999).

102 Kovács 1999, 149; Bíró 2009, 56, stb.

103 Jelen tanulmányban elsősorban a vicusok épületeiről, szerkezetéről, kormeghatározásáról volt szó, holott nagyon érdekes lenne a leletek alapján kirajzolódó gazdasági életet, a helyi kerámiagyártást, az egyre romanizálódó életmódot is nyomon követni, de ezt itt hely hiányában csak összefoglaló jelleggel érinthettem.

104 Lásd részletesebben RUPNiK 2012.

105 ОттомÁNYi 2007a, 206-209; 2012a, 375-380.
} 
A fazekas kemencék a helyi kerámiagyártás bizonyítékai. Mind Pátyon, mind Budaörsön kerültek elő fazekas kemencék, elsősorban a római kor első két évszázadából. ${ }^{106} \mathrm{~A}$ legegyszerübb gödörben való égetéstől, a kelta hagyományú, kétosztatú kemencéken át a már fejlettebb, négyszögletes kemencékig sokféle változat előfordul (Fig. 23.1-3, 5-6). ${ }^{107}$ A fémművességre utaló vassalakok a budaörsi telep életének elejéhez és a végéhez köthető műhelyekből, gödrökből származnak. ${ }^{108}$ Egy nyeles vaskanál a bronz vagy ólomöntés kelléke volt. Pátyon a fémművességet a salakos műhelyeken túl egy félkész bronzcsat jelzi. ${ }^{109}$ Félkész csonttárgyak illetve a csontmegmunkálás során lehullott szarv és agancstöredékek a késő kelta illetve az 1-2. század fordulójára keltezhető objektumokból származnak Budaörsön. ${ }^{110}$

A limes hátországában lévő, 5-10 km-es körzeten belül található vidéki telepeknél, mind az 1-2. századi bennszülött telepek, mind a későbbi villák, vicusok esetében felmerül a katonaság ellátásának szerepe. ${ }^{111} \mathrm{Ez}$ főleg a mezőgazdasági termelésre vonatkozik. Budaörs, lévén mindössze 6 km-re Albertfalva és Campona táborától, 9-12 km-re az aquincumi ala és legio táboroktól, beleesik ebbe a körbe. Közvetlen bizonyítékot erre az ellátó funkcióra nem találunk. Esetleg csak az a 4. századi bélyeges tégla töredék említhető meg (legio II adiutrix) mely egy szemétgödörből került elő a telep északi részén. Polgári építkezéshez a katonaság nem szállított építőanyagot, de egyes emberek kaphattak a katonaságtól téglát különböző szolgáltatásokért pl. gabonaszállítás stb. cserébe. A késői időszak nagyméretű tároló edényei, kétfülű korsói is alátámasztják a még virágzó mezőgazdasági termelést a 4. századi telepen. ${ }^{112}$

A település lakóinak romanizáltsági fokát jelzik a római étkezési kultúrára jellemző dörzstálak és a római díszedények, a terra sigillaták egyre növekvő mennyisége. Életmódjukra és az írásbeliségére utalnak a bronz és vas írószerszámok, mécsesek, lámpafüggesztők, a vas gyertyatartó, mérleg súlyok, ládika tartozékok, stb. (Fig. 24.1-3, 5). A hétköznapi szórakozás maradványai a csont dobókockák, kerek zsetonok, gyerekjátékként használható csonttárgyak, agyag és fémkorongok, stb. A viseleti tárgyak, ékszerek (Fig. 16.2), tükrök, orvosi és kozmetikai eszközök mind a telep lakóinak életét tükröző apróságok, amelyek a kerámia, bronz ${ }^{113}$ és üvegedények maradványaival együtt kirajzolják egy több évszázadon keresztül lakott település mindennapjait.

\section{Temetö}

Pátyon és Budaörsön a vicushoz tartozó temető is előkerült a telep feltárásával párhuzamosan. Mind a két helyen a patakparti telephez képest a dombtetőn, körülbelül 50 méterre a település szélétől kezdődött. Budaörsön egy összefüggő egységet alkot, amelyet három oldalról sikerült lehatárolni (Fig. 4). Budapest irányába a folytatása már elpusztult, csak egy 1970-es évekbeli leletmentés hamvasztásos sírjai jelzik, hogy túlnyúlt a legutóbb feltárt területen. ${ }^{114}$

106 OtтомÁnyi 2012a, 154-165: a 2-3. században főleg Aquincumból szerezték be az edényeket. Csak a telep életének elején és valószínűleg a végén gyártották helyben a termékeket, bár a 4. századból nem maradtak ránk fazekas kemencék. Elhelyezkedésük többnyire a telep északi szélén, a vicus ipari negyedében.

107 Budaörsön a telep más részeiről előkerült rontott edénytöredékek és az összeolvadt, kora római ólommáz is helyi gyártásra utal.

108 OттомÁNyi 2012a, 114. kép. A fémművességben használt vasszerszámok, kalapács, ár, lyukasztó, gyaluvas is a helyi gyártás bizonyítékai.

109 OtTományi 2007a, 154. kép 9.

110 OттомÁNYi 2012a, 277-278, 221. kép.

111 SzŐNyi 2005, 407; KoczTUR 1985, 81; KovÁcs 1999, 157-163.

112 OtTomÁnYi 2012a, 380, 80. kép 6.

113 SEY 2012.

114 MRT 7, 5/10. lh; OtTOMÁNYi - MESTER - Mráv 2005, 38-55; OtTOMÁNYi 2014a, 52-78. 
Pátyon, avar és Árpád-kori temető közzé ékelődve, több kisebb sírcsoportból állt és ezek folyamatosan kísérik a telepet, hosszában a patak mentén. Három oldalát itt is lehatároltuk, de északra, Páty felé kérdéses meddig tart (Fig. 22.1). ${ }^{115}$ Biatorbágyon a telep feltárása nem érintette a temetőt, ellenben a patak másik partján 2004-ben, avar sírokkal keveredve előkerült egy római temetőrészlet (benne egy esetleges halomsír bronzedény készletével), ${ }^{116}$ sőt talán ide tartozik a budaörsi Metro áruház építésekor talált kocsisír és a közelében feltételezett halomsír is, az autópálya alatt (Fig. 2.2). ${ }^{117}$

\section{Összefoglalás}

Összefoglalóan megállapíthatjuk, hogy a három, egymástól közel azonos távolságban (6 km) fekvő vicus helyzete (út és patak mellett), kora és fejlődési fázisai nagyon hasonlóak. Mindháromnál kimutathatóak kelta előzmények és fejlődésük töretlen volt az 1. század folyamán. A kőépítkezés már korán, a 2. század első harmadában Hadrianus uralkodása alatt megindult. A markomann háborúk idején elpusztultak és a Severus-kori újjáépítés során nem egy villagazdaság jött létre a bennszülött telep helyén, hanem a korábbi vicus folytatódott kiteljesedve és megerősödve. A 250-es években bekövetkező barbár támadást elrejtett éremleletek jelzik (Biatorbágy és Budaörs), majd újraindult a telep élete legkésőbb a 3. század utolsó harmadában és töretlenül fejlődött a 4 . század végéig. A telepek pusztulásának végét gödörbe temetett halotttak, és egyéb 5. század elejére keltezhető leletek (csontfésű, besimított kerámia, stb.) jelzik. Lakosságukban - a feliratos kövek és az ékszerek alapján - mind a bennszülött vezetőréteg, mind a veteránok megtalálhatóak a kora római időszakban, sőt a Birodalom nyugati feléből jött idegen elemek is kimutathatóak. A markomann háborúk után a feliratok az aquincumi városi tisztségviselők és katonák vezető szerepét tükrözik. Az 5. század elején már idegen, valószínűleg germán elemek is megjelennek a továbbélő római lakossággal keveredve.

A vicusokra jellemző szerkezeti sajátosságok, például belső kövezett utak, kerítésfalak mind a három telepnél jelentkeztek. Szentélyeket is mind a három telepen feltételezhetünk, de középület már csak Budaörsön került elő. Mind építkezési kultúrájukban, szerkezetükben és lakosságuk összetételében túllépnek a kőépítkezés nélküli falvakon, ugyanakkor sem nagyságukban, sem jogállásukban nem érik el a városok színvonalát, villáknak pedig egyértelmüen nem tarthatók. ${ }^{118}$ A három telep közül leggazdagabb a pagus Herculius központi vicusa, Budörs volt. A Budaörs, Kamaraerdei-dűlőben feltárt, több mint négy évszázadon át lakott vicus Teuto(...) néven azonosítható római település újabb bizonyíték a rómaiak által létrehozott területi, adminisztratív egységek, a pagus és vicus meglétére Pannoniában. ${ }^{119}$

115 MARÓTI 2001; OTTOMÁNYI 2012b.

116 MARÓTI - REPISZKY 2008.

117 MRT 7, 36/22. lh; MrÁv 2014, 118

118 Legkevesebbet a biatorbágyi településről tudunk. Egyrészt itt volt legkisebb a feltárt terület, másrészt az ásatás jelenleg publikálatlan, így a következtetések e telep esetében még változhatnak.

119 A pátyi telep térképeit Viemann Zsolt, a budaörsi telep térképeit Érdi Benedek készítette. Munkájukat ezúton is köszönöm. 


\section{Irodalom}

AlföLDy, G. 1959: Municipális középbirtokok Aquincum környékén. Antik Tanulmányok 6, 19-29.

BEszÉDEs, J. 2010: Újabb koracsászárkori teleprészlet Lágymányoson. Aquincumi Füzetek 16, 113-115.

Bíró, M. 1974: Roman Villas in Pannonia. Acta Archaeologica Academiae Scientiarum Hungaricae 26, 23-57.

Bíró, Sz. 2007: A Sokoró vidéke a római korban. In: Bíró, Sz. (ed.): Fiatal Római Koros Kutatók I. Konferenciakötete. Győr, 17-33.

Bíró, Sz. 2009: Neue Angaben zum vicus von Arrabona. In: Bíró, Sz. (ed.): Ex officina. Studia in honorem Dénes Gabler. Győr, 49-61.

Borhy, L. - Bartus, D. - Stibrányi, M. 2012: Two Altars -two Aurelii Valentes. Acta Classica Universitatis Scientiarum Debreceniensis 48, 133-140.

BudAi BAlogh, T. 2009: Pannonische Grubenhäuser. Abriss der römerzeitlichen Geschichte der eingetieften Wohnhäuser. In: Bíró, Sz. (ed.): Ex officina. Studia in honorem Dénes Gabler. Győr, $77-110$.

GABLER, D. 1993-1994: A Balatontól északra lévő terület római kori településtörténetének néhány kérdése. Veszprém Megyei Múzeumok Közleményei 19-20, 149-155.

GABleR, D. 2003: Falusi jellegủ telepek Pannoniában. In: VIsy, Zs. (ed.): Magyar régészet az ezredfordulón. Budapest, 241-243.

GABLER, D. 2005: Augusteische Sigillaten in Budaörs. Italischer Import in der vorrömischen Zeit im pannonischen Raum. Acta Archaeologica Academiae Scientiarum Hungaricae 56, 133-175.

Gabler, D. 2012: A budaörsi terra sigillaták. In: OtтomÁnyi, K. (ed.): Római vicus Budaörsön. Régészeti Tanulmányok. Budapest, 409-453.

Hanel, N. - Schucany, C. (eds.) 1999: Colonia - municipium - vicus, Struktur und Entwicklung städtischer Siedlungen in Noricum, Rätien und Obergermanien. British Archaeological Reports. International Series 783. Oxford.

HÁrshegyi, P. 2008: Római kori településrészlet feltárása Budaörs határában. Aquincumi Füzetek 14, $158-164$.

Hensen, A.1999: Der römische vicus von Wiesloch (Rhein-Neckar-Kreis). In: Hanel, N. - Schucany, C. (eds.): Colonia - municipium - vicus, Struktur und Entwicklung städtischer Siedlungen in Noricum, Rätien und Obergermanien. British Archaeological Reports. International Series 783. Oxford, 83-93.

KABA, M. 1983-1984: III. századi éremlelet Budaörsről. Numizmatikai Közlemények 82-83, 7-17.

Kocztur, É. 1985: Adalékok Solymár római kori történetéhez. Folia Archaeologica 36, 75-83.

KovÁcs, P. 1997-1998: Civitas eraviscorum. Antaeus 24, 278-295.

KovÁcs, P. 1999: Vicus és castellum kapcsolata az alsó-pannoniai limes mentén. Studia Classica (Ser. Hist. I.) PPKE BTK, Piliscsaba.

KovÁcs, P. 2002a: New Roman Inscriptions from Szigetszentmiklós. Specimina Nova, 71-76.

Kovács, P. 2002b: Oppidum Scarbantia Julia. Antik Tanulmányok XLVI, 147-191.

Kovács, P. 2008: Ager Aquincensis (CIL III. Praefationes). In: Kovács, P. - FeHÉn, B. (eds.): Studia Epigraphica Pannonica 1. Budapest, 55-59. 
KovÁcs, P. 2013: Territoria, Pagi and Vici in Pannonia. In: Eck, W. - FeHér, B. - KovÁcs, P. (eds.): Studia Epigraphica in memoriam Géza Alföldy. Bonn, 131-154.

Lohner, U. 1999: Zivile vicus im Umfeld von Flavia Solva. In: Hanel, N. - Schucany, C. (eds.): Colonia - municipium - vicus, Struktur und Entwicklung städtischer Siedlungen in Noricum, Rätien und Obergermanien. British Archaeological Reports. International Series 783. Oxford, 29-41.

Magyar, Zs. 2014: Research in a late La Tène - early Roman settlement at Bátaszék, Körtvélyesdűlő. The early Roman period. In: Bínó, Sz. (ed.): Dörfliche Siedlungen der römischen Kaiserzeit im mittleren Donauraum. Győr.

Maróti, É. 2001: Páty (Terminál Rt). In: Kisfaludi, J. (ed.): Régészeti Kutatások Magyarországon 1998. Archaeological Investigation in Hungary 1998. Budapest 2001, 161.

MARóti, É.- REPISZKY, T. 2008: Bronzedények a biatorbágyi római temetőből (Budapark). In: OTTOMÁNYI, K. (ed.): Képek a múltból. Az elmúlt évek ásatásaiból Pest megyében (Perspectives on the Past. Major Excavations in County Pest). Szentendre, 62-63.

MARótı, É. - MrÁv, Zs. 2004: Kiadatlan római kori kőemlékek Pest megyéből. I. Feliratos kőemlékek. Studia Comitatensia 28, 249-253.

Merczi, M. 2012: A Budaörs, Kamaraerdei-dűlőben feltárt római vicus fibulái. In: OtToMÁNYi, K. (ed.): Római vicus Budaörsön. Régészeti Tanulmányok. Budapest, 473-528.

Miklósity SzőKe, M. 2009: Biatorbágy, Kukorica-dűlő. In: Kisfaludi, J. (ed): Régészeti Kutatások Magyarországon 2008. Archaeological Investigation in Hungary 2008. Budapest 2009, 152-153.

Mikцósity Szőke, M. 2010: Biatorbágy - Kukorica-dűlő (Pest megye, Tópark Irodapark építését megelőző régészeti kutatások). In: Kvassay, J. (ed.): Évkönyv és jelentés a K.Ö.SZ. 2008. évi feltárásairól. Budapest, 62-64.

Mikıósity SzőKe, M. 2012: Római kori pecsételt kerámia Biatorbágy-Kukorica-dűlő lelőhelyről. In: Kvassay, J. (ed.): Évkönyv és jelentés a K.Ö.SZ. 2009. évi feltárásairól. Budapest, 223-251.

MrÁv, Zs. 2006: Paradeschild, Ringknaufschwert und Lanzen aus einem römerzeitlichen Wagengrab in Budaörs. Die Waffengräber der lokalen Elite in Pannonien. Archaeologiai Értesítő 131, 33-73.

MrÁv, Zs. 2007: Római kori feliratok és faragott kőemlékek Pátyról. Studia Comitatensia 30, 403-423.

MrÁv, Zs. 2010: Fémberakással díszített kora császárkori phaleracsüngő Biatorbágyról (Pest megye, Magyarország). In: Kvassay, J. (ed.): Évkönyv és jelentés a K.Ö.SZ. 2008. évi feltárásairól. Budapest, 139-161.

MRÁv, Zs. 2012: Kora császárkori militaria a Budaörs-Kamaraerdei-dűlői vicus területéről. In: ОттомÁNYI, K. (ed.): Római vicus Budaörsön. Régészeti Tanulmányok. Budapest, 583-612.

MrÁv, Zs. 2014: Római feliratok és faragott kőemlékek Budaörsről. A kocsiút végállomása: a túlvilág. In: Ottományi, K. - Mráv, Zs. - Filipszky, I. - Mester, E.: Antik gyökereink. Budaörs múltja a régészeti leletek fényében (2nd ed.). Budaörs, 79-137.

MrÁv, Zs. - OtTomÁnYi, K. 2004: DE(I) FU(N)C(TUS) EXP(EDITIONE) GERM(ANICA) LAURI(ACO) MORTE SUA. Egy Caracalla alamann expeditiója során elhunyt katona szarkofágja Budaörsről. Specimina Nova 18, 49-98.

Mráv, Zs. - Ottományi, K. 2005: A Pag(us) Herc(ulius) és vicusainak Terra Mater oltára Budaörsről. Specimina Nova 19, 71-118.

MrÁv, Zs. - Szabó, Á. 2012: Új adatok Aquincum Severus-kori városi elitjéhez. M. Antonius Victorinus Aquincumban és Budaörsön. In: Kovács, P. - FeHér, B. (eds.): Studia Epigraphica Pannonica. Vol. IV. TITE Könyvek 2. (Történelmi Ismeretterjesztő Társulat Egyesület). Budapest, $120-140$. 
MRT 7.: TORMA, I. (ed.): Magyarország Régészeti Topográfiája 7. Pest megye régészeti topográfiája XIII/1. A budai és szentendrei járás. Budapest 1986.

OtтомÁNyi, K. 2001: Hunkori sírok a pátyi temetőben. Archaeologiai Értesítő 126, 35-74.

OттомÁnyi, K. 2005: Die spätlaténezeitliche-römische Siedlung von Budaörs. Acta Archaeologica Academiae Scientiarum Hungaricae 56, 67-132.

OттомÁNyı, K. 2007a: A pátyi római telep újabb kutatási eredményei. Studia Comitatensia 30, 7-238.

OттомÁNyi K. 2007b: A római kor emlékei Pest megyében (őslakosság, településszerkezet, temetkezés, vallás, betelepített barbárok). In: Torma, I. - Fancsalszky, G. (eds.): Pest megye monográfiája I/1. A kezdetektől a Honfoglalásig. Budapest, 249-341.

OттомÁNyi, K. 2008: Késő római - kora népvándorlás kori település részlet Biatorbágyról. Archaeologiai Értesitő 133, 133-197.

OттомÁNyi, K. 2009: Eingeglättete Gefässe aus der letzten Periode der Siedlung von Budaörs. In: Bíró, Sz.(ed.): Ex officina. Studia in honorem Dénes Gabler. Győr, 411-442.

OtтомÁnyi, K. 2010: Biatorbágy, Káposztás-dűlő. In: Kisfaludi, J. (ed): Régészeti Kutatások Magyarországon 2009. Archaeological Investigation in Hungary 2009. Budapest 2010, 149-150.

OtтomÁnyi, K. 2012a: Római vicus Budaörsön. In: OtтomÁnyi, K. (ed.): Római vicus Budaörsön. Régészeti Tanulmányok. Budapest, 9-407.

Ottományi, K. 2012b: Késő római sírcsoportok a pátyi temetőben. Archaeologia, Altum Castrum online magazin. 1-16. (A Fiatal Római koros régészek VI. konferenciájának előadásai). http://archeologia.hu/keso-romai-sircsoportok-a-patyi-temetoben

OттомÁNYi, K. 2014a: A budaörsi település periódusai. Kőépítkezés a Kamarerdőben feltárt római telepen. Sírformák a budaörsi római temetőben. In: OttománYi, K. - Mráv, Zs. - Filipszky, I. MEsTER, E.: Antik gyökereink. Budaörs múltja a régészeti leletek tükrében. (2nd ed.). Budaörs, 9-78.

OттомÁNYi, K. 2014b: In den Boden eingetiefte Häuser vicus von Budaörs. In: Bíró, Sz. (ed.): Dörfliche Siedlungen der römischen Kaiserzeit im mittleren Donauraum. Győr.

OtTomÁnyi, K. - GableR, D. 1985 Római telepek Herceghalom és Páty határában. (A pátyi terra sigilláta). Studia Comititatensia 17, 185-272.

Ottományi, K. - Mester, E. - MrÁv, Zs. 2005: Antik Gyökereink. Budaörs múltja a régészeti leletek fényében. Budaörs.

Póczy, K. 2004: Aquincum. Budapest római kori történelmi városmagja. Budapest.

Prohászka, P. 2007: Páty régészeti és numizmatikai emlékei Várady József levelei tükrében. Studia Comitatensia, 30, 424-439.

Rajna, A. - Kovács, Á. 2010: Törökbálint, Tópark (Kukorica-dűlő). In: Kisfaludi, J. (ed): Régészeti Kutatások Magyarországon 2009. Archaeological Investigation in Hungary 2009. Budapest 2010, 375.

REDő, F. 2012: Újabb híradás a biatorbágyi kincsleletről. Magyar régészet (on-line magazin) 2012, 1-4.

REMÉNYI, L. - TóTH, A. 2004: Őskori telepek, római kori árokrendszer, avar sírok Biatorbágy-Hoszszúrétek lelőhelyen. Aquincumi Füzetek 10, 160-167.

RePISZKy, T. 2004: Biatorbágy, Káposztás-dűlő. In: Kisfaludi, J. (ed): Régészeti Kutatások Magyarországon 2003. Archaeological Investigation in Hungary 2003. Budapest 2004, 166. 
Repiszky, T. 2005: Páty, Alsó-Hegy-alja. In: Kisfaludi, J. (ed): Régészeti Kutatások Magyarországon 2004. Archaeological Investigation in Hungary 2004. Budapest 2005, 265.

RupNik, L. 2012: Római kori vastárgyak Budaörs 2. lelőhelyről. In: OtтомÁNYi, K. (ed.): Római vicus Budaörsön. Régészeti Tanulmányok. Budapest, 553-583.

SEY, N. 2012: Római kori bronztárgyak Budaörs 2.lh. feltárt településének területéről. In: OTTOмÁNYI, K. (ed.): Római vicus Budaörsön. Régészeti Tanulmányok. Budapest, 613-643.

Sommer, C. S. 2002: Recent developments in south-west Germany (eastern Germania Superior - western Raetia). In: Freeman, PH. - Bennett, J. - Fiema, Zв. T. - Hoffmann, B. (eds.): Limes XVII. Proceedings of the XVIIIth International Congress of Roman Frontier Studies held in Amman, fordan (September 2000). British Archaeological Reports. International Series 1084. Oxford.

SzIRMAI, K. 1984: Beszámoló a budatétényi római telep feltárásáról II. rész (1974-1977). Budapest Régiségei $26,153-182$.

SzőNYI, E. 1996: Römerzeitliche Altansässigensiedlung von Ménfőcsanak (Umgebung von Győr). Arheološki Vestnik 47, 249-256.

SzŐNyı, E. 2005: Landwirtschaftliche Siedlungen hinter dem Limes. Balácai Közlemények 9, 401-412.

SzŐNYI, E. 2008: Házak Mursella municipiumban. Arrabona 46/2, 35-47.

TARPIn, M. 1999: Colonia, municipium, vicus: Institutionen und Stadtformen. In: HANEL, N. - SchUCANY, C. (eds.): Colonia - municipium - vicus, Struktur und Entwicklung städtischer Siedlungen in Noricum, Rätien und Obergermanien. British Archaeological Reports. International Series 783. Oxford, 1-10.

Torbágyi, M. 2007: Páty-Malom-dűlő 1997-1999. évi ásatás érmeinek értékelése. Studia Comitatensia 30, 276-299.

Tóтн, E. 2003: Római utak a Dunántúlon. In: Visy, Zs.(ed.): Magyar régészet az ezredfordulón. Budapest, 218-221.

VIsy, Zs. 1994: Die ländliche Besiedlung und Landwirtschaft in Niederpannonien. In: Bender, H. Wolf, H. (eds.): Ländliche Besiedlung und Landwirtschaft in den Rhein-Donau-Provinzen des Römischen Reiches. Passauer Universitätschriften zur Archäologie. Bd. 2. Espelkamp, 421-449.

Zsıdi, P. 2004: Aquincum topográfiája. Specimia Nova 18, 167-226. 


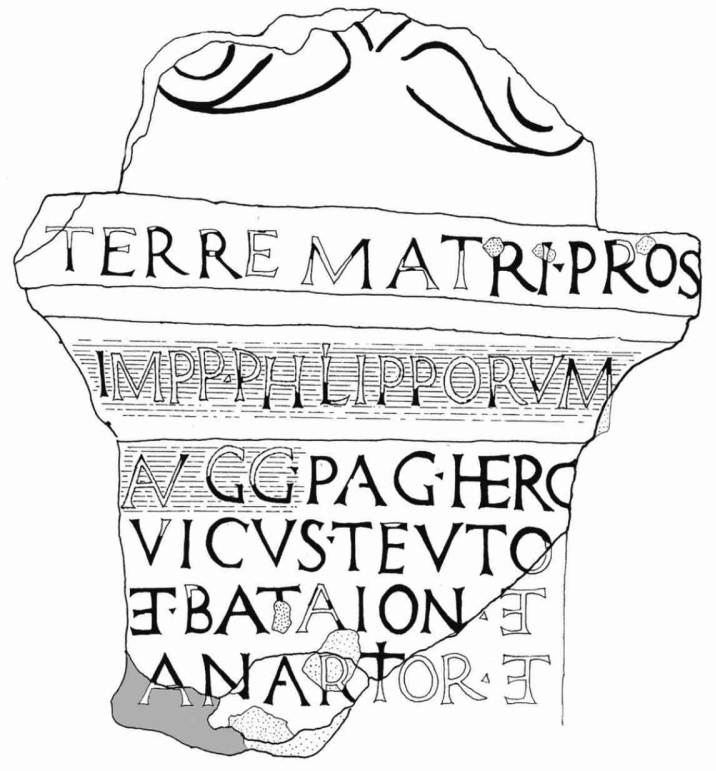

1

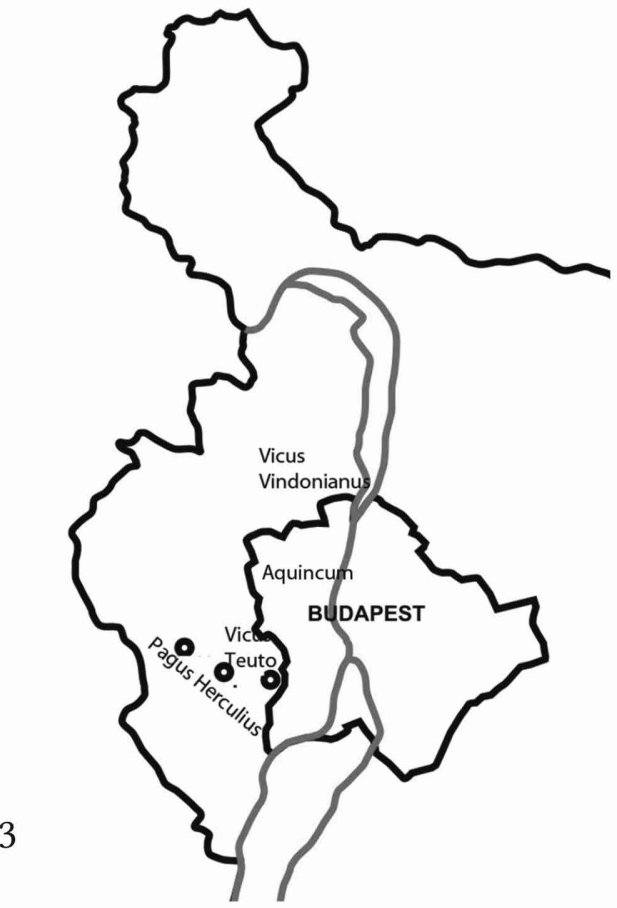

Terr(a)e [•] Matri a pros(alute)| $[[I[m p p$ (eratorum) $]$ - Pbi [l]ip[po]rum $]] \mid[[$ Augg(ustorum) · ] ] pag(us) . Herc(ulius), | vicus (!) · Teuto(-..) $\left.\right|^{5}$ et - Bataion(is) [. et] |Anarti[or(um). et? $]|++[\ldots,-]| \ldots$.

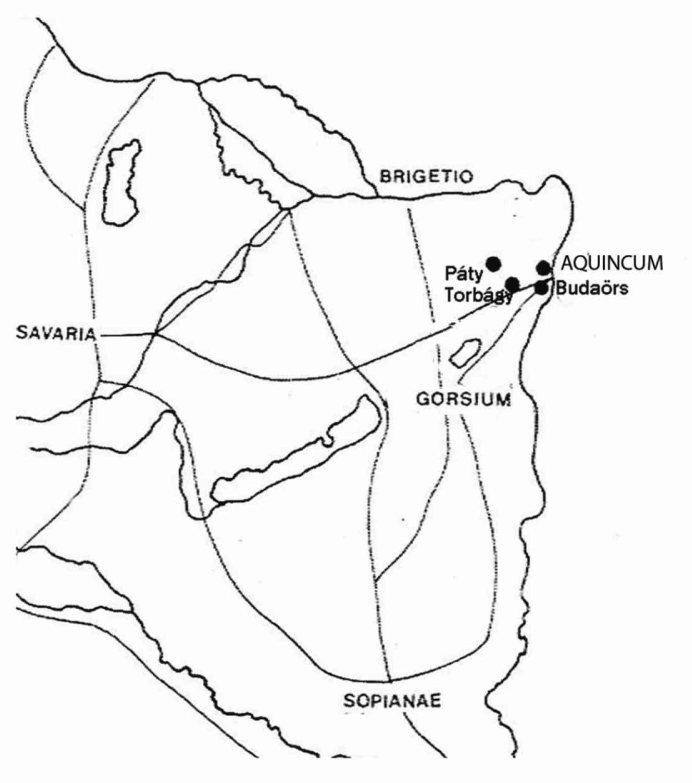

Fig. 1. 1-2. A pagus Herculius vicusainak nevét tartalmazó oltárkő Budaörsről (MRÁv - OTTOMÁNYi 2005). 3. Pest megye térképe az ismert vicus nevekkel. 4: Pannonia úthálózata. 


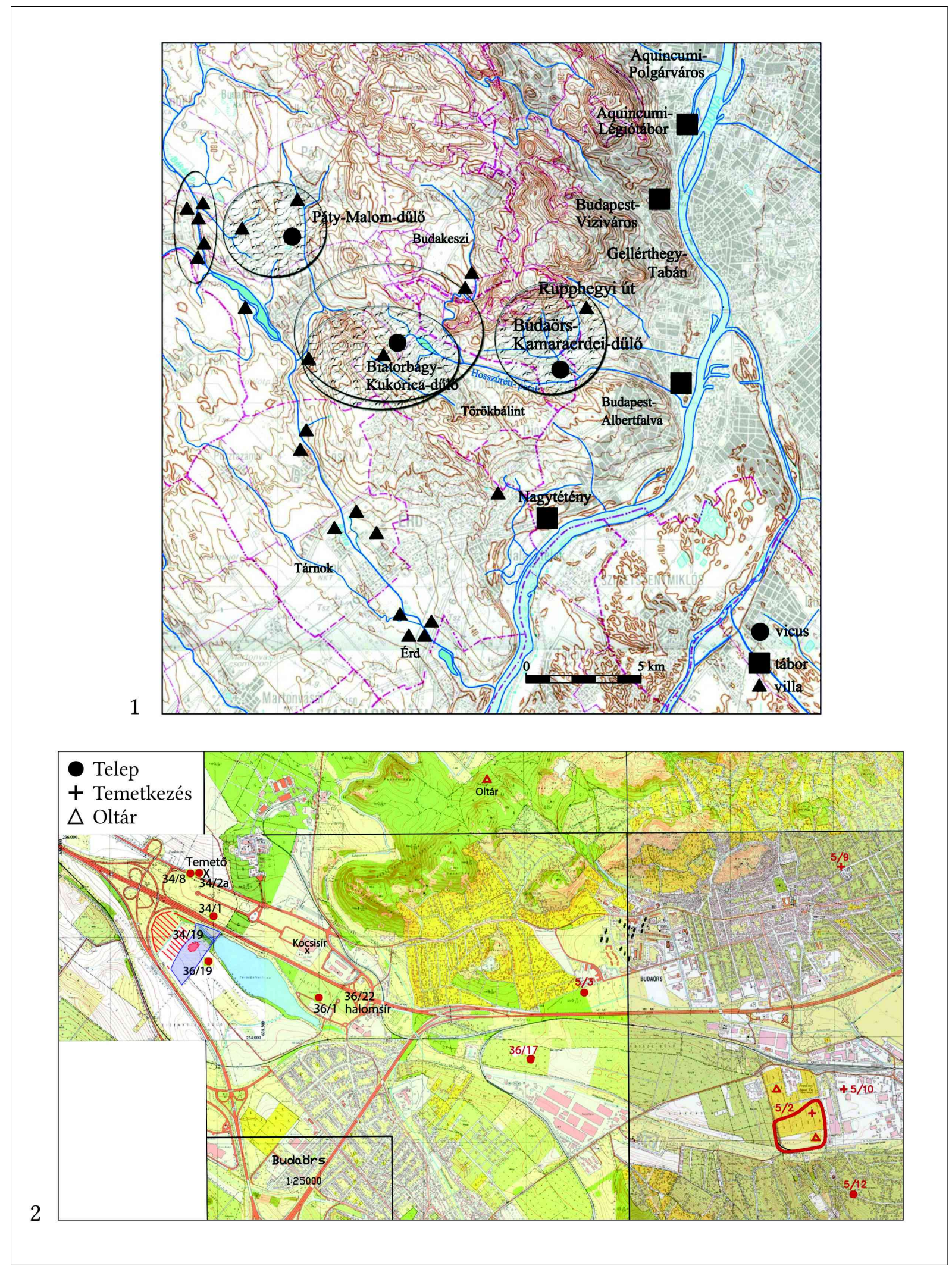

Fig. 2. 1. Aquincum DNy-i körzetében található vicusok, villák és táborok. 2. A budaörsi és biatorbágyi vicushoz tartozó lelőhelyek (MRT 7). 

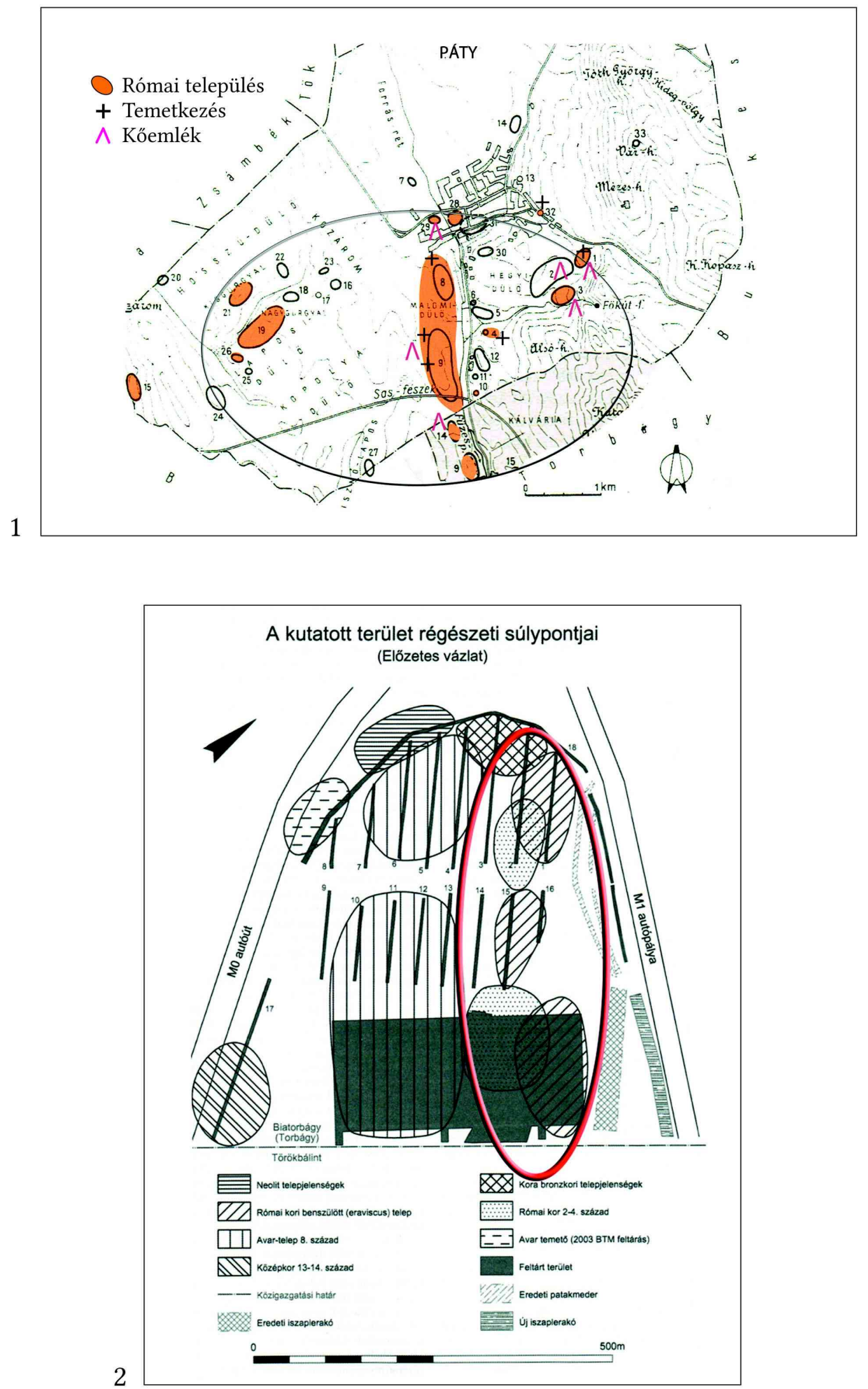

Fig. 3. 1. A pátyi vicus feltételezett kiterjedése. 2. A biatorbágyi feltárás áttekintő térképe (MıкLósıTy SzőKE 2009), a római lelőhely jelölésével. 


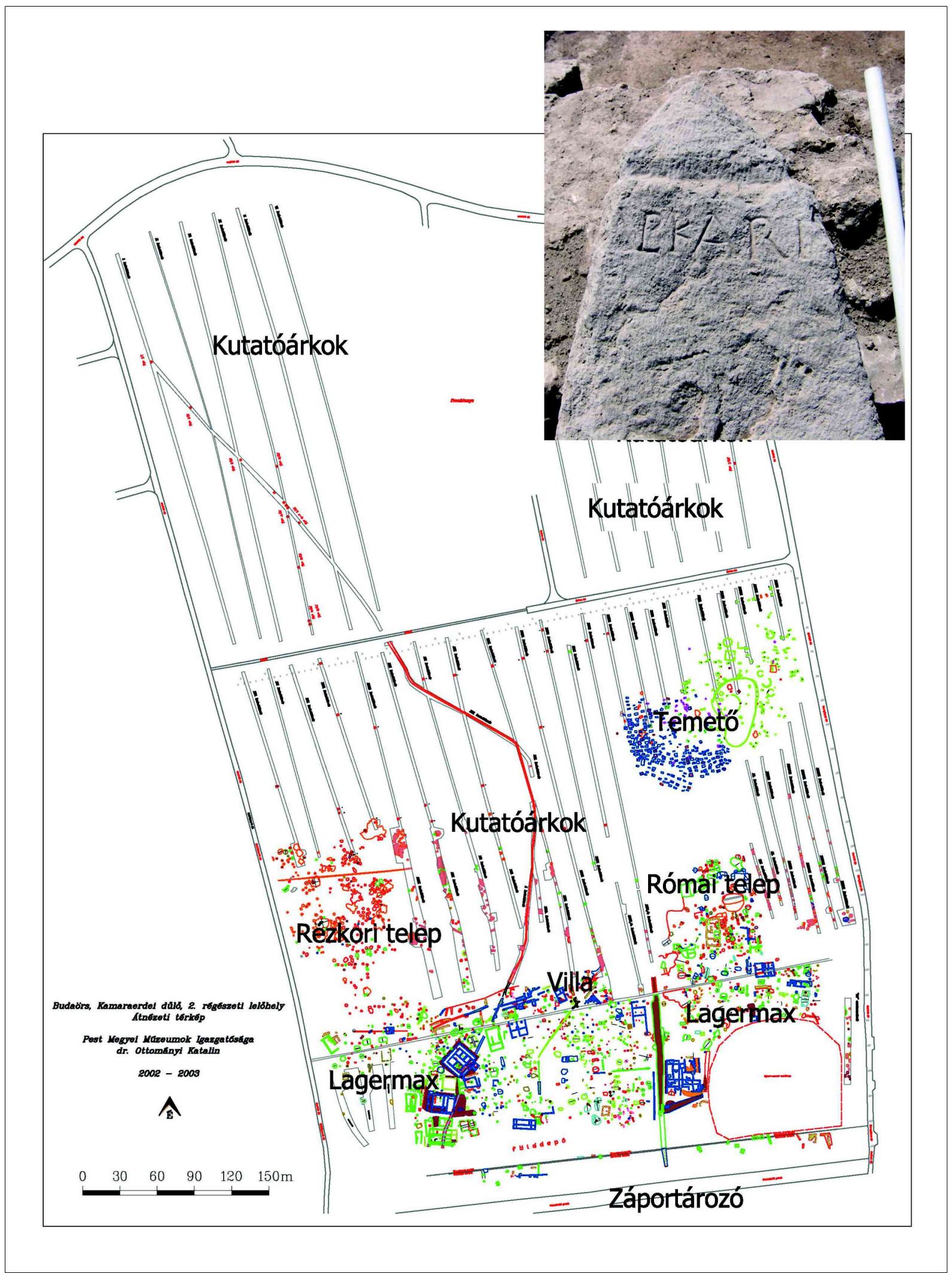

Fig. 4. A budaörsi feltárás áttekintő térképe és Ulpius Karus határköve. 


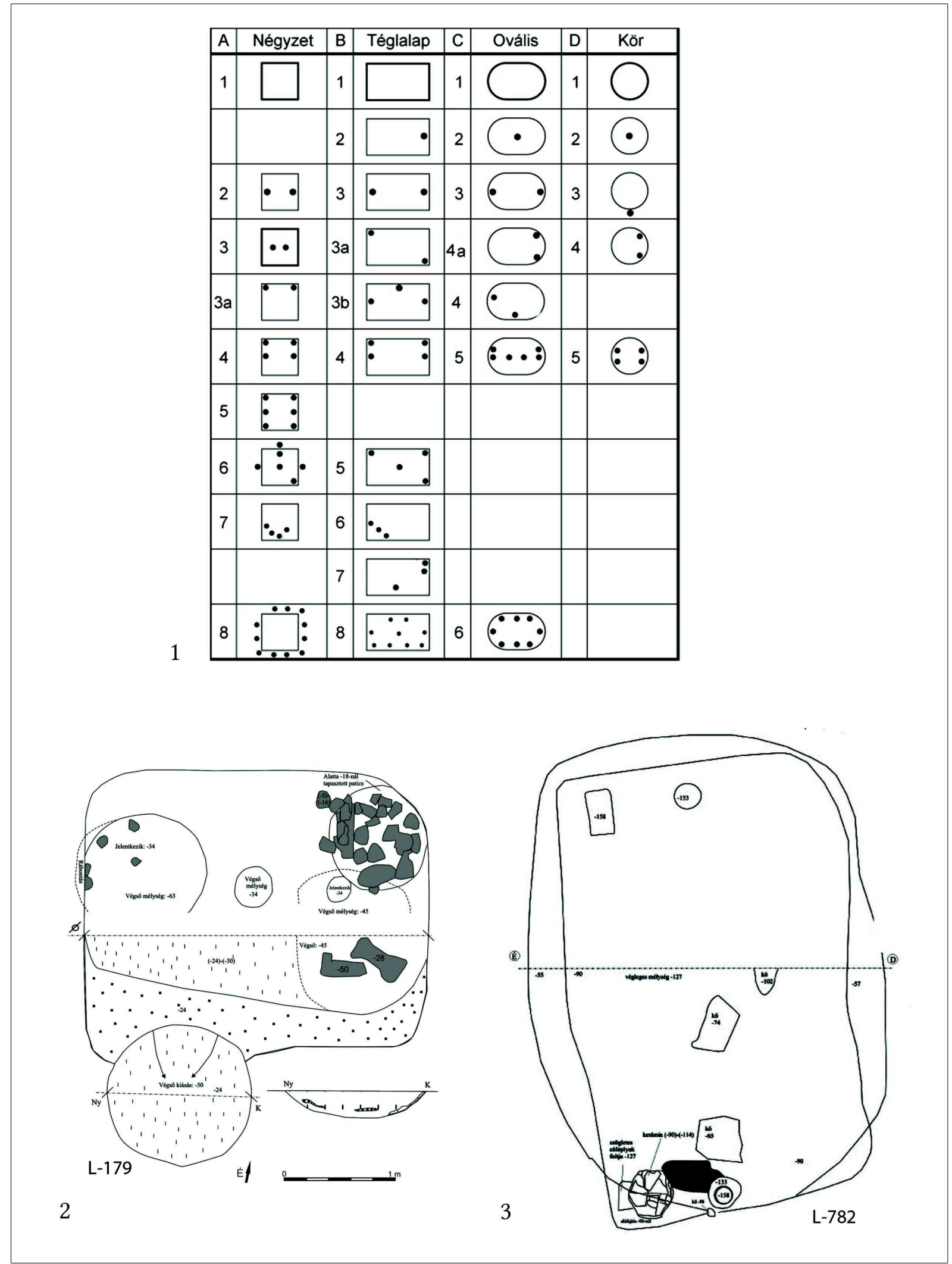

Fig. 5. 1. A budaörsi vicus földbemélyített házainak típustáblája. 2. Kemencés, több gödrös ház/műhely Budaörsről. 3: Téglalap alakú, 1. századi lakóház (Budaörs). 

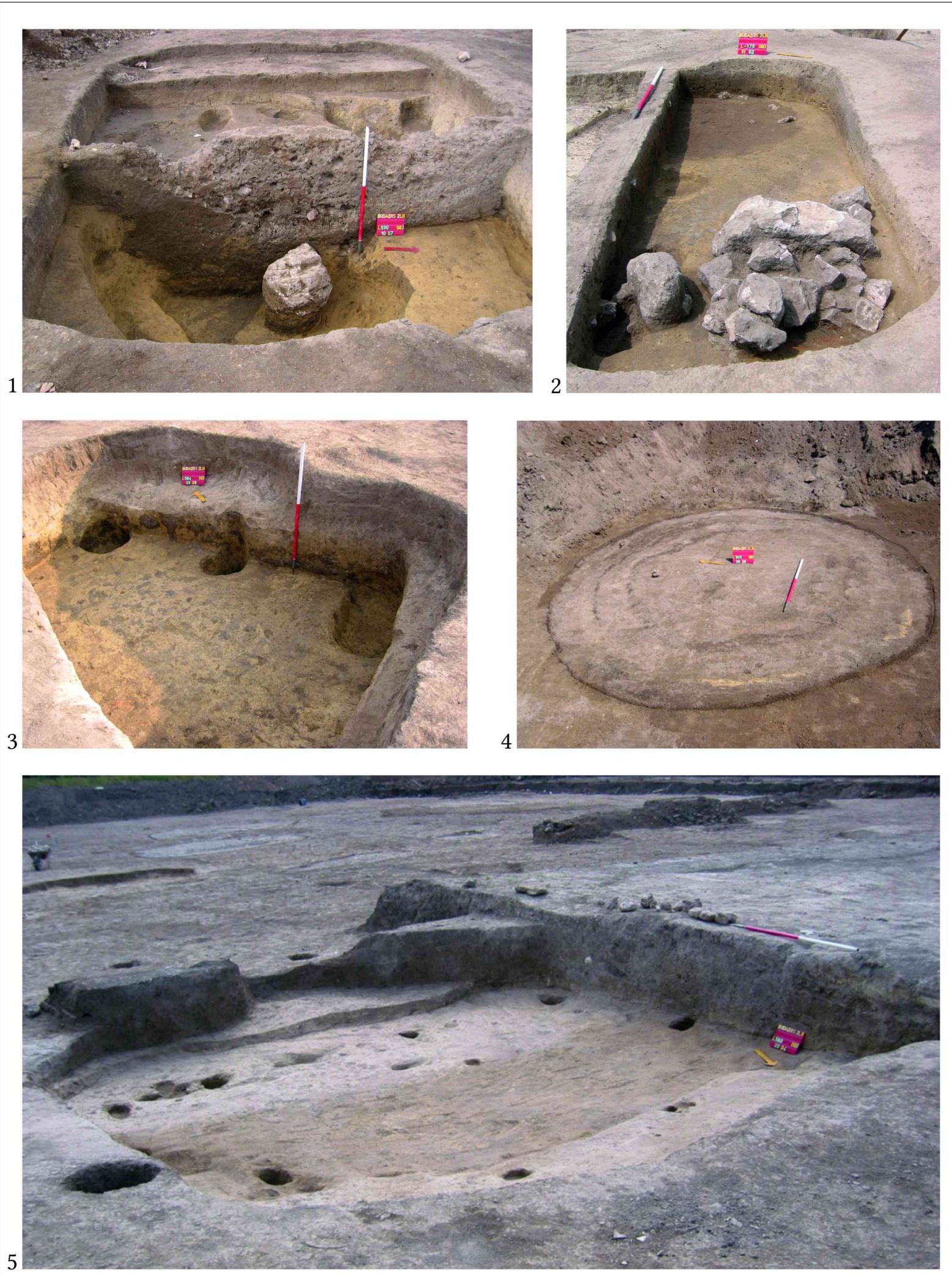

Fig. 6. Földbemélyített házak a budaörsi vicusból. 


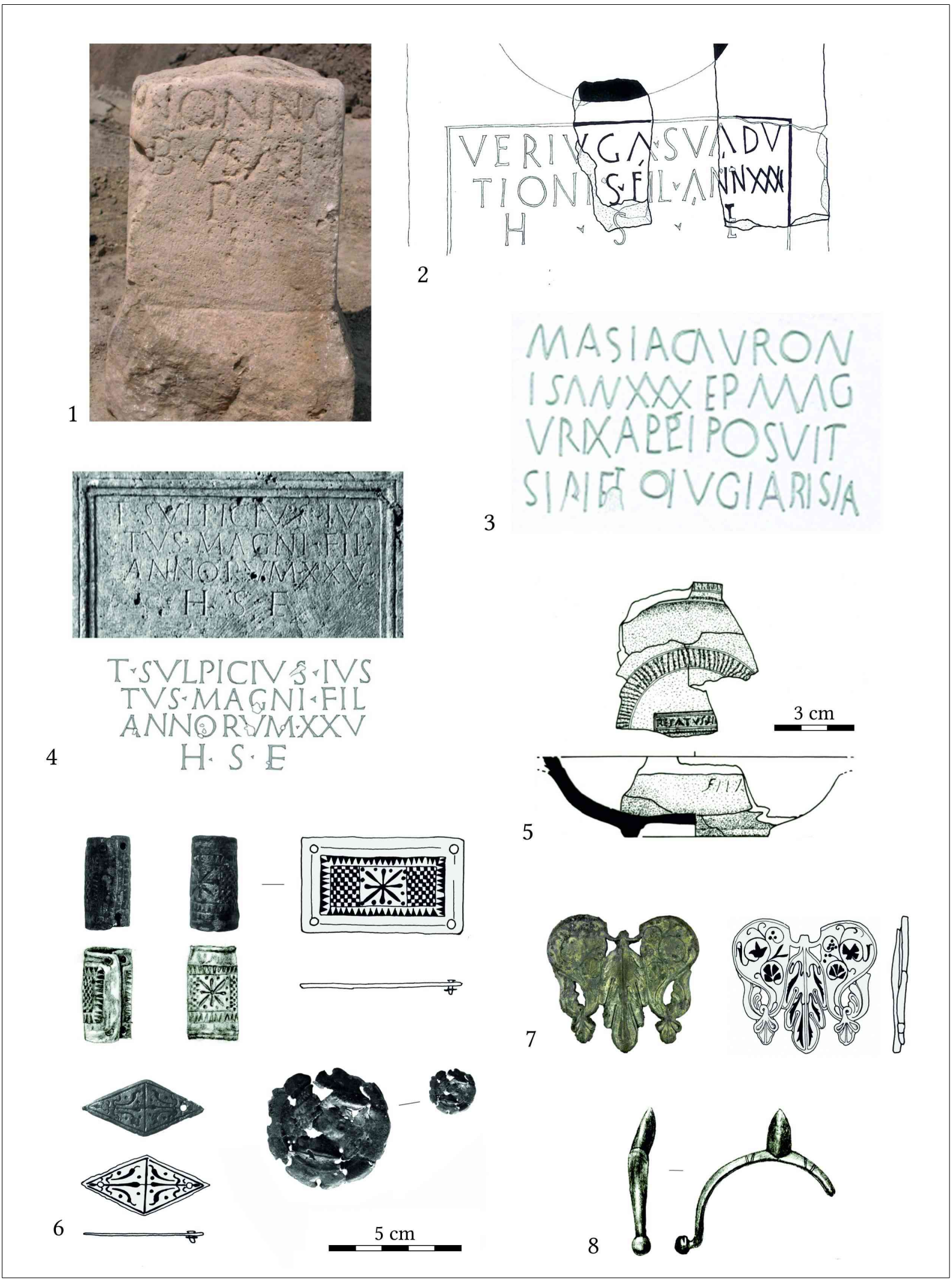

Fig. 7. Kora római lakosság.1. Nonnus, Busaius fiának síroltára Budaörsről. 2. Veriuga sír sztéléje a budaörsi temetőből (MrÁv 2014). 3. Pátyi sírfelirat bennszülött névvel (Mráv 2007). 4. T. Sulpicius Iustus sírköve Budaörsről (MrÁv 2014). 5. Resatus névbélyeges bepecsételt tál, a tulajdonos bekarcolt nevével (Budaörs). 6. 1. századi militaria leletek Budaörsől (MrÁv 2012). 7. Flavius-kori phalera csüngő Biatorbágyról (MrÁv 2010). 8. Sarkantyú (Budaörs). 


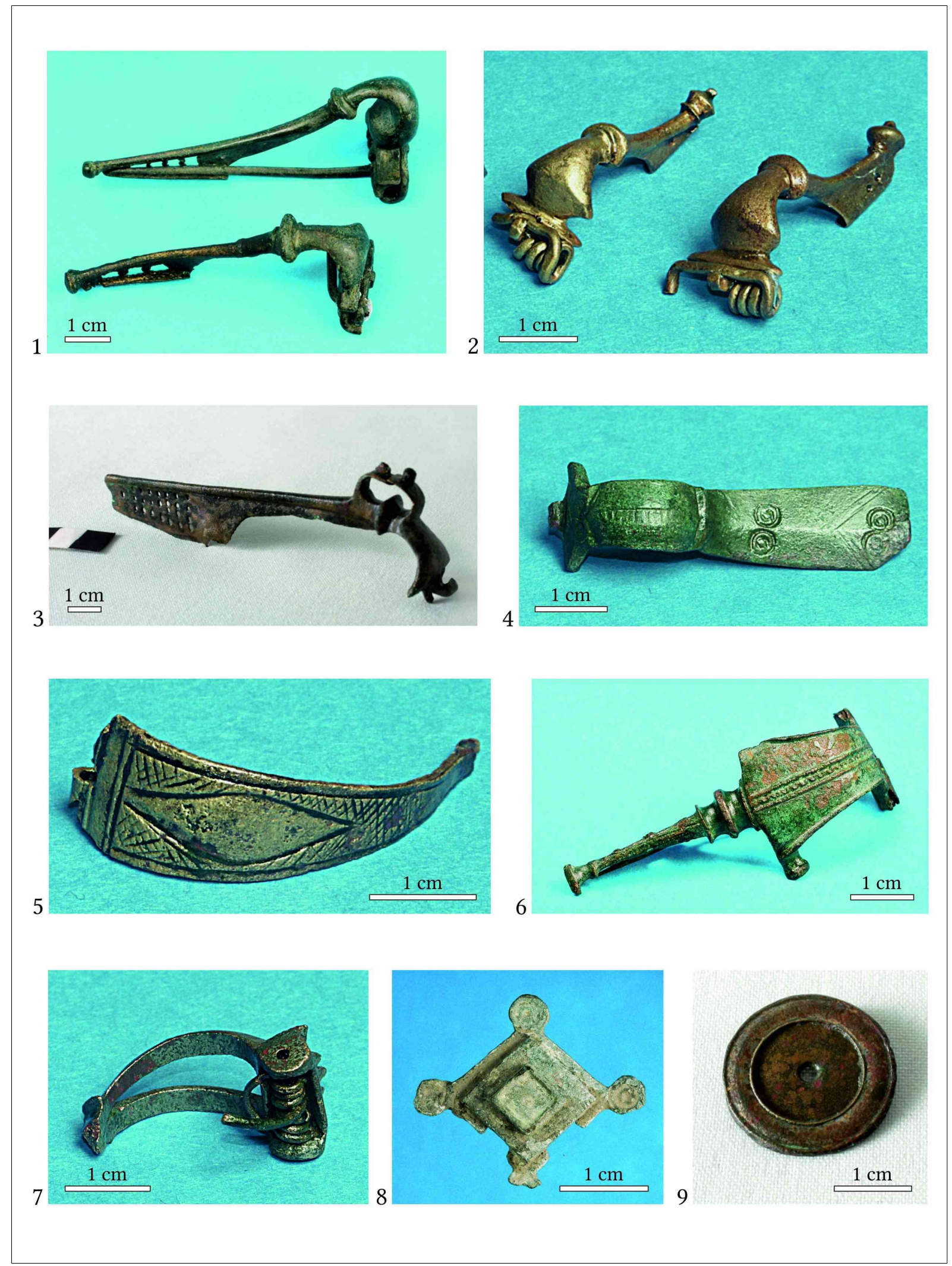

Fig. 8. Etnikumjelző fibulák. 1-2. Egygombos, erősprofilú fibulák (Páty). 3. Szárnyas fibula (Budaörs). 4. Szemes fibula (Páty). 5. Alesiai típusú, italiai fibula (Páty). 6. Galliai import fibula (Páty). 7. Villás kengyelủ fibula (Páty). 8-9. Rajna vidéki emailos és korong alakú fibulák (Páty, Budaörs). 


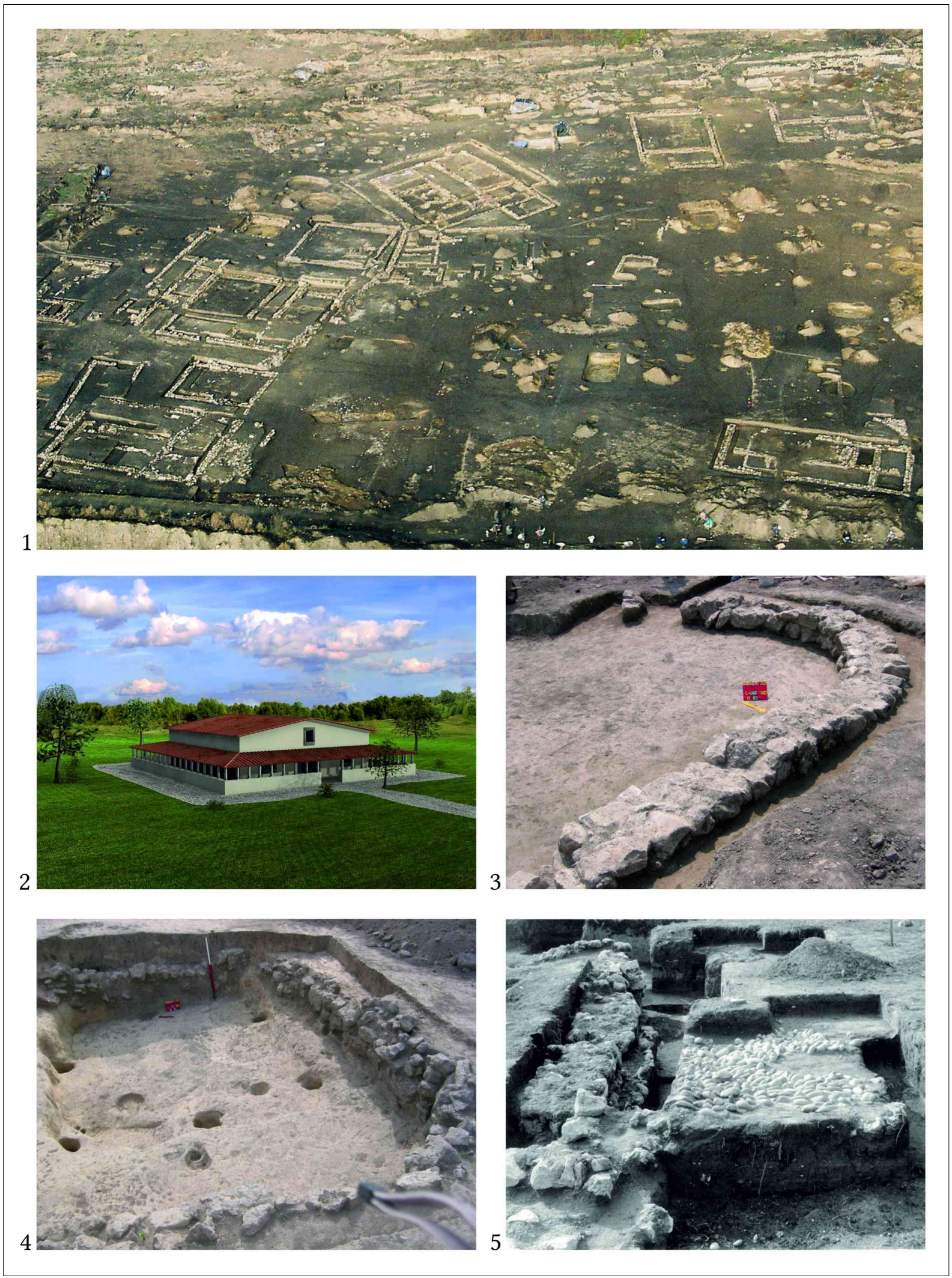

Fig. 9. Kora római kőépületek a budaörsi vicusban. 1. légifotó a nyugati félköríves épületsorról. 2. A középfolyosós épület rekonstrukciója (Pazirik Kft). 3. apszisos épület maradvány. 4. félig földbemélyített ház kőfalakkal megtámasztva. 5. Kaba M. ásatásának egyik kőépülete kavicsos útfelszínnel. 


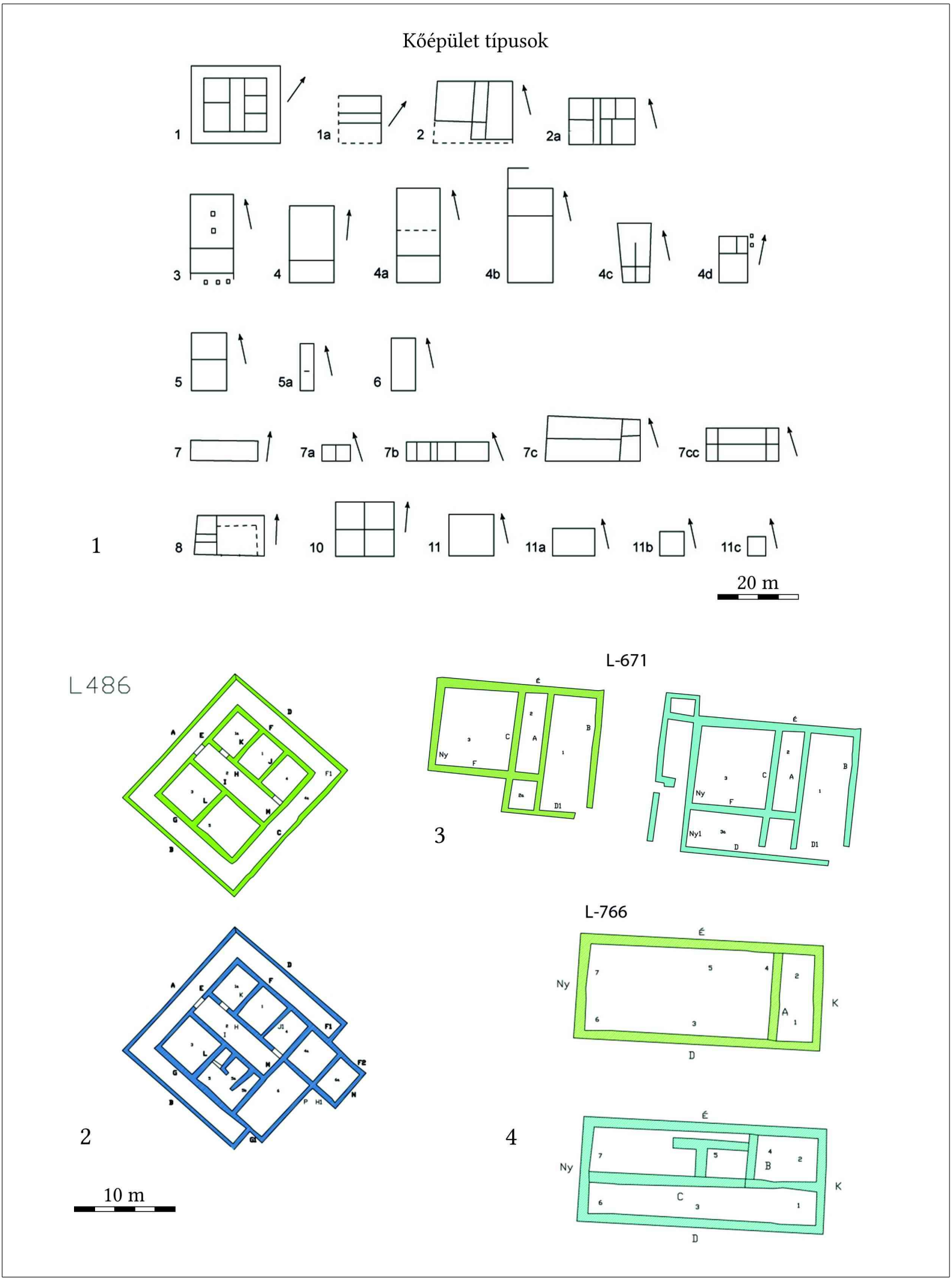

Fig. 10. 1. Kőépület típusok a budaörsi vicusban. 2. A középfolyosós kőépület 1. és 3. periódusa. 3. Közép és oldalfolyosós épület alaprajza (1-2. periódus). 3. Téglalap alakú, egyharmadnál osztott épület alaprajza (1. és 3. periódus). 

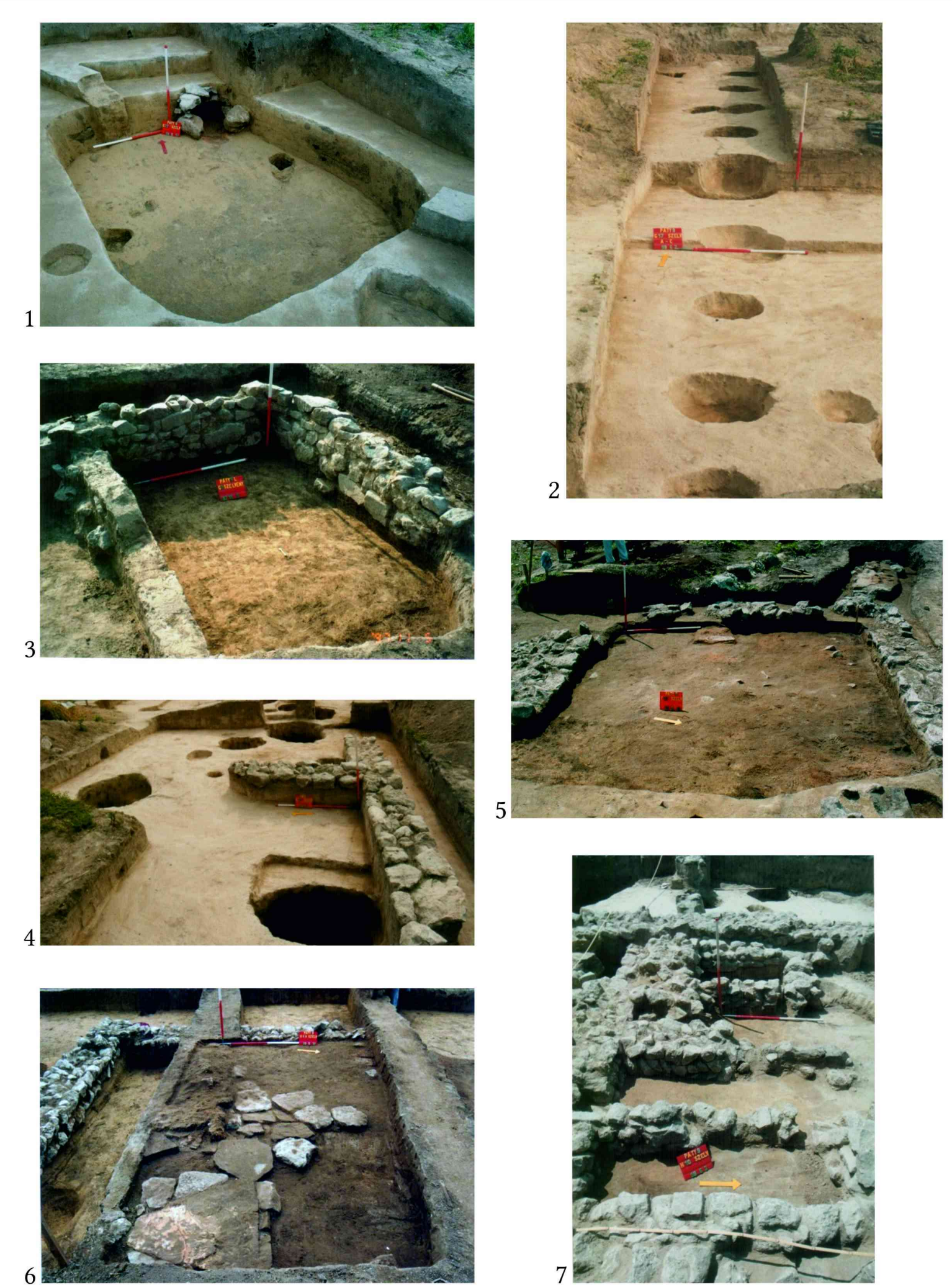

Fig. 11. A pátyi vicus lakóépületei. 1: földbemélyített ház kőkemencével (2. század). 2: cölöpszerkezetes ház (2-3. század). 3: négyszögletes kőépület (2. század). 4: Severus-kori kőépület a kora római tároló vermek felett. 5. Leégett, 3-4. századi kőépület. 6-7. Késő római kövezett udvar s belső helyiségek a „H” kőépületben. 


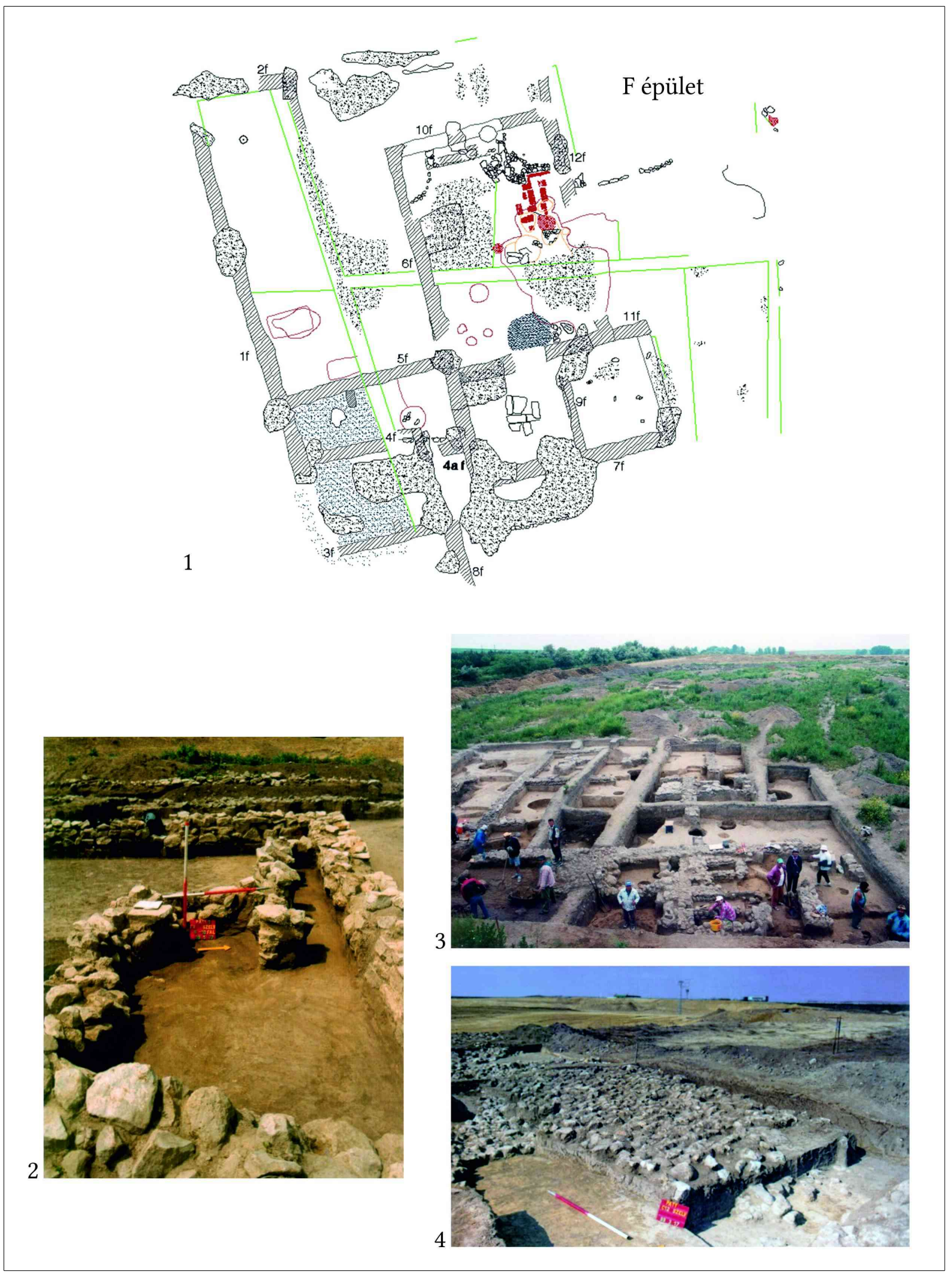

Fig. 12. A pátyi vicus kő építkezései (Severus-kor, késő római kor). 1-2. „F” kőépület. 3. „H” kőépület. 4. kövezett út részlet. 


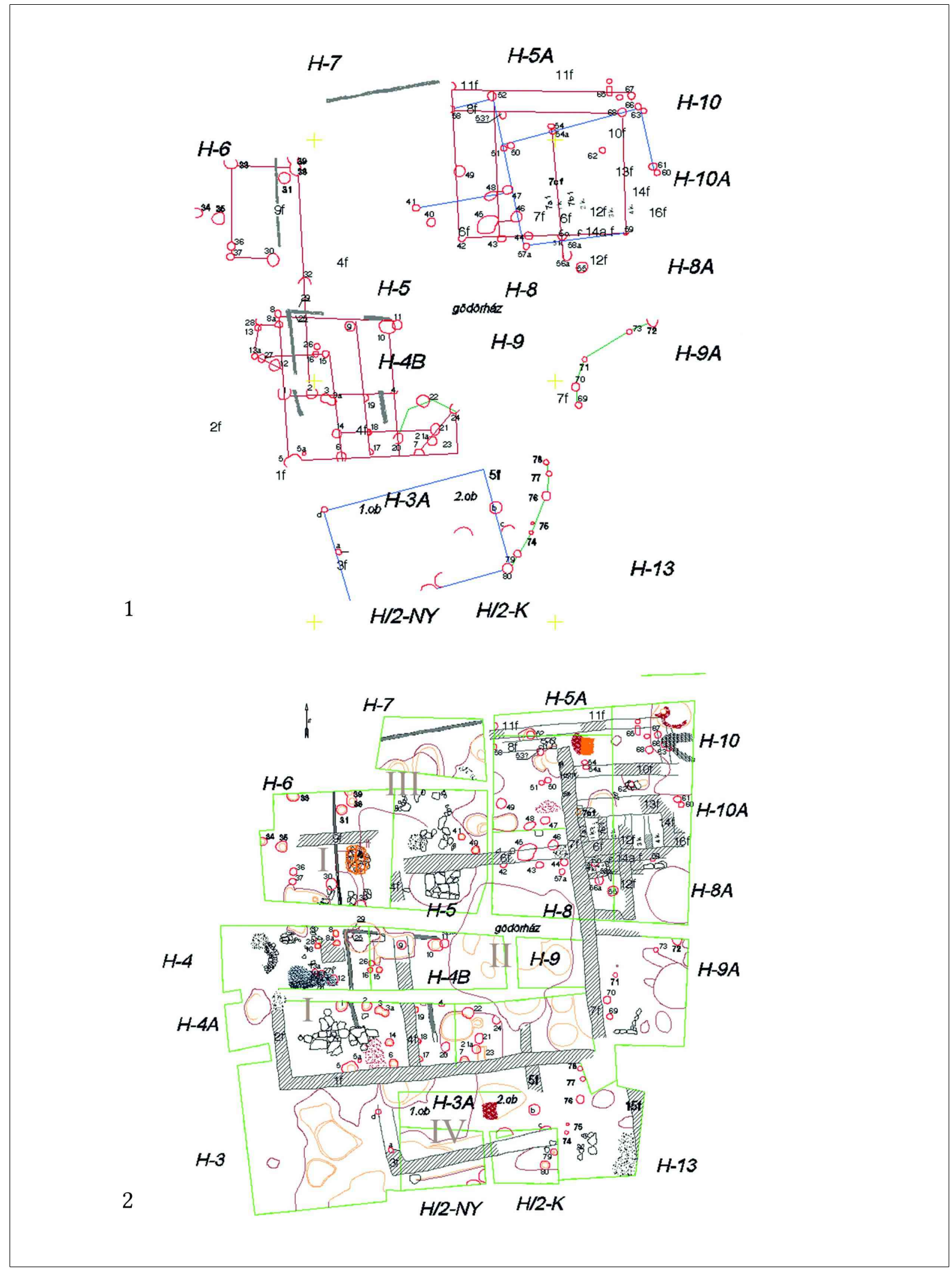

Fig. 13. Páty, „H” terület. 1. a kőépület alatti cölöpszerkezetes házak feltételezett alaprajzai. 2. a „H” kőépület alaprajza. 


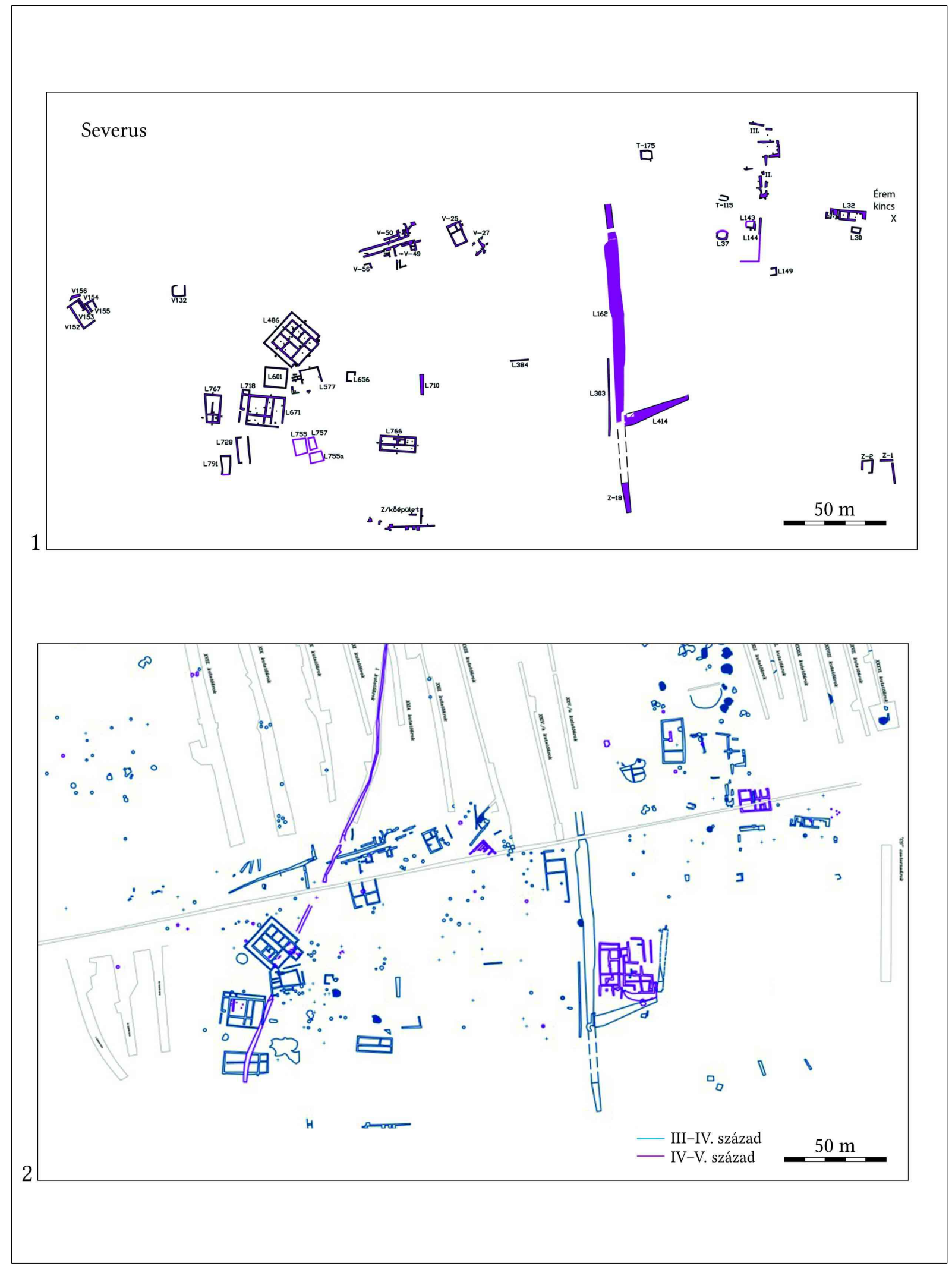

Fig. 14. 1. A budaörsi vicus Severus-kori nagyobb kőépületei. 2. A budaörsi vicus késő római beépítettsége. 

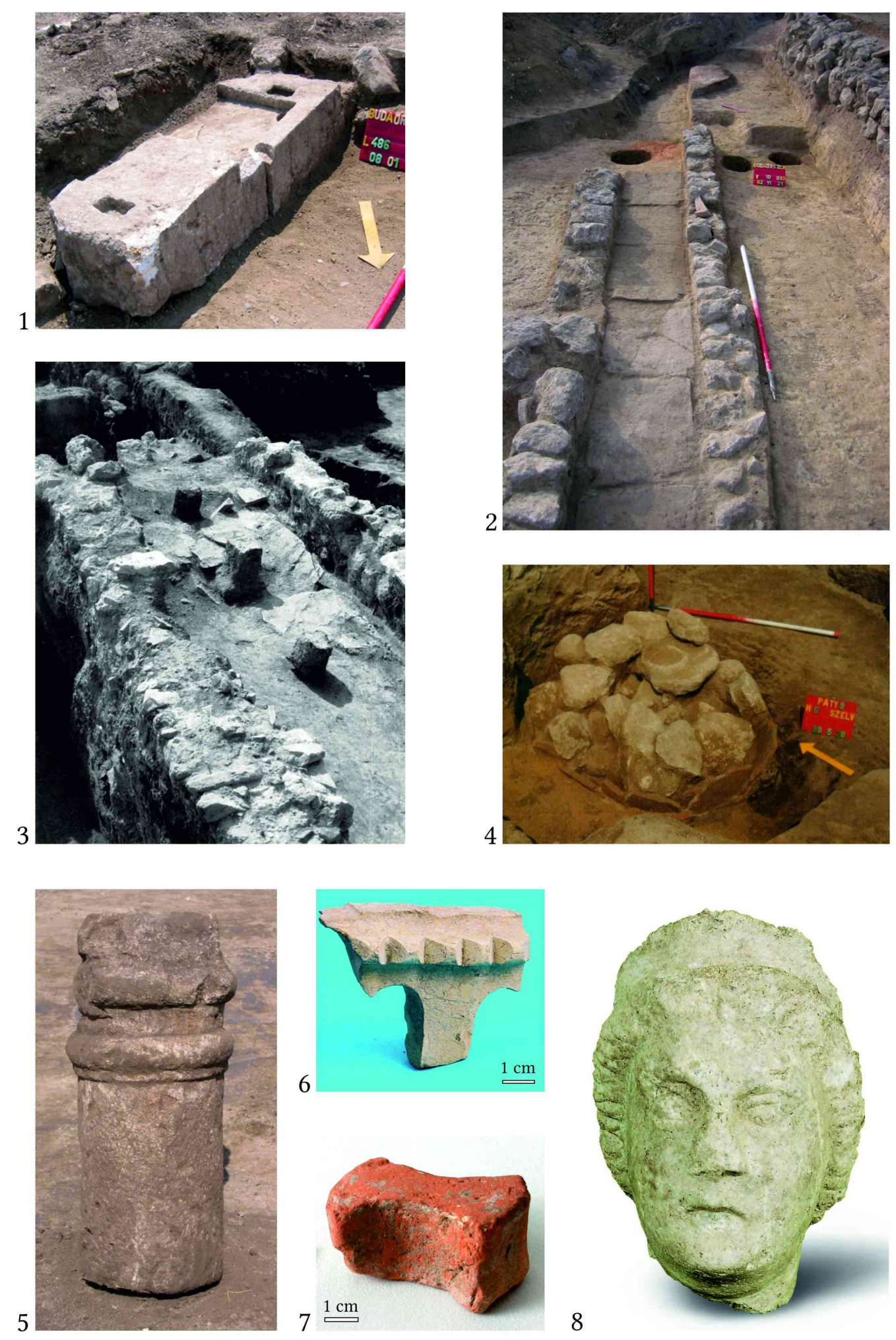

8

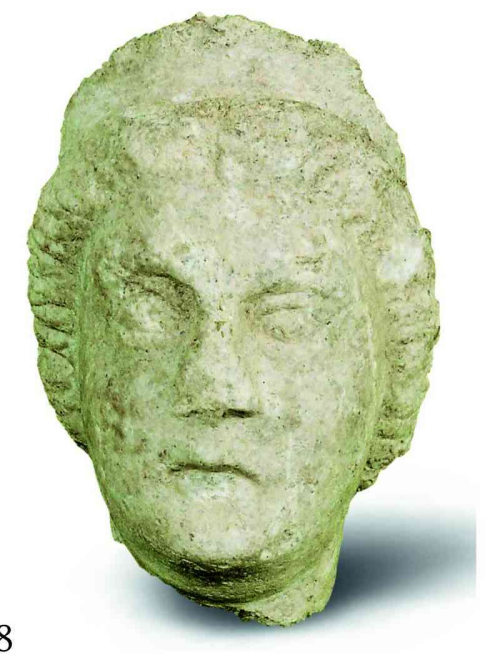

Fig. 15. Épület tartozékok, díszek. 1. küszöbkő a budaörsi középfolyosós épületből. 2. Fütőcsatorna (Budaörs). 3. hypocaustum folyosó Kaba M. ásatásából (Budaörs). 4. kőboltozatos téglakemence (Páty, „H” kőépület). 5. oszloptöredék Budaörsről. 6. agyag kapumodell töredék (Budaörs). 7. padlótégla (Budaörs). 8. szoborfej a középfolyosós épületből (Budaörs). 

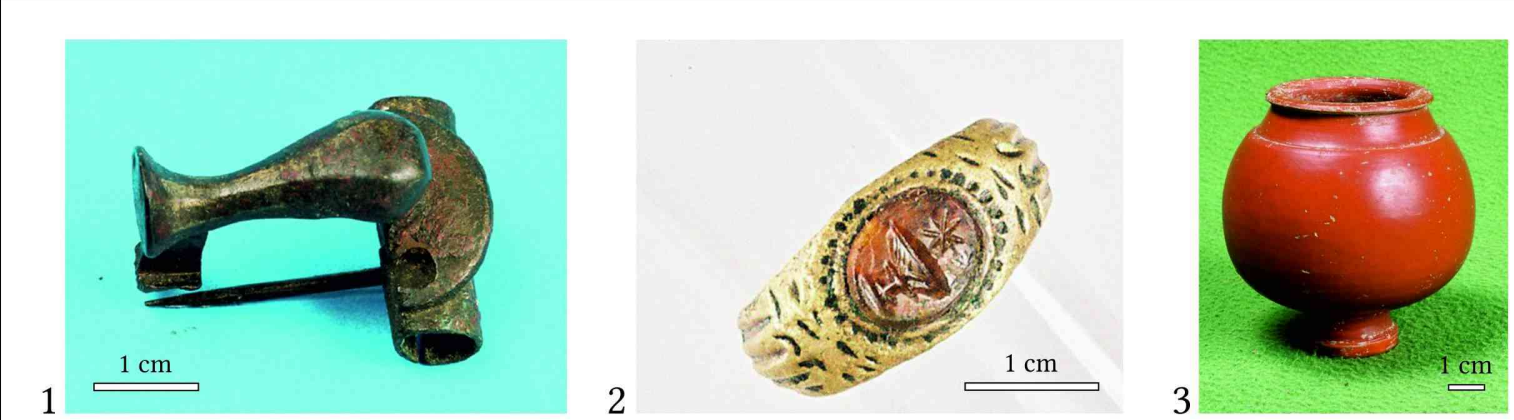

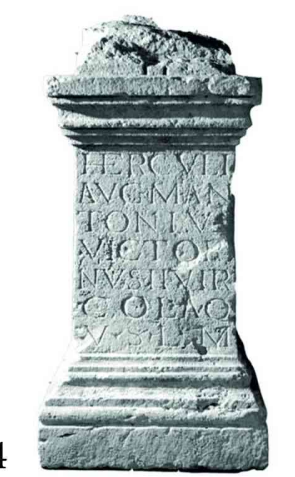

HERCVLI AVG:M $M N$ TON I V VICTOIR NVS.IIVIR C O LAO $V r S+L>M$

4
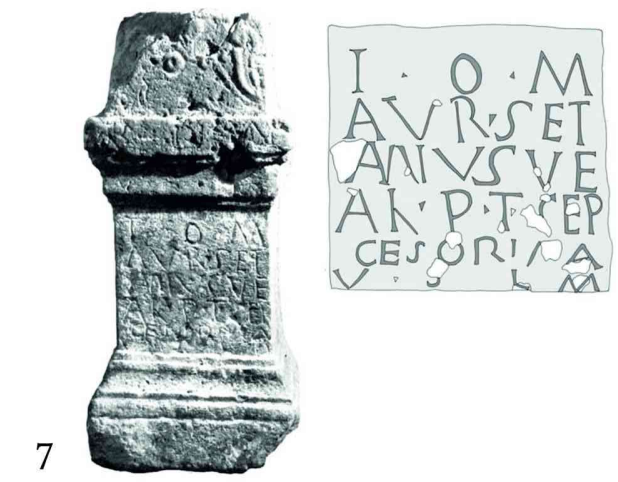

10

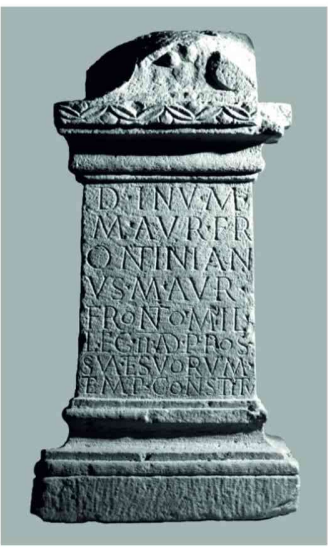

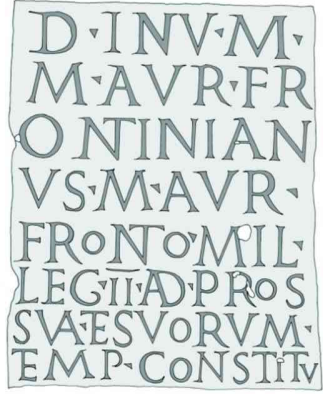

VS.VICTORINVSTCONONI

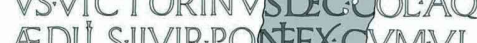
PIA.SPECTATA.VXORE.POSVIT

5

NMPHIS PERENBS N.VA L. KA R V S

DEC.COL'AQ I I V I R 6 V.S. I rM
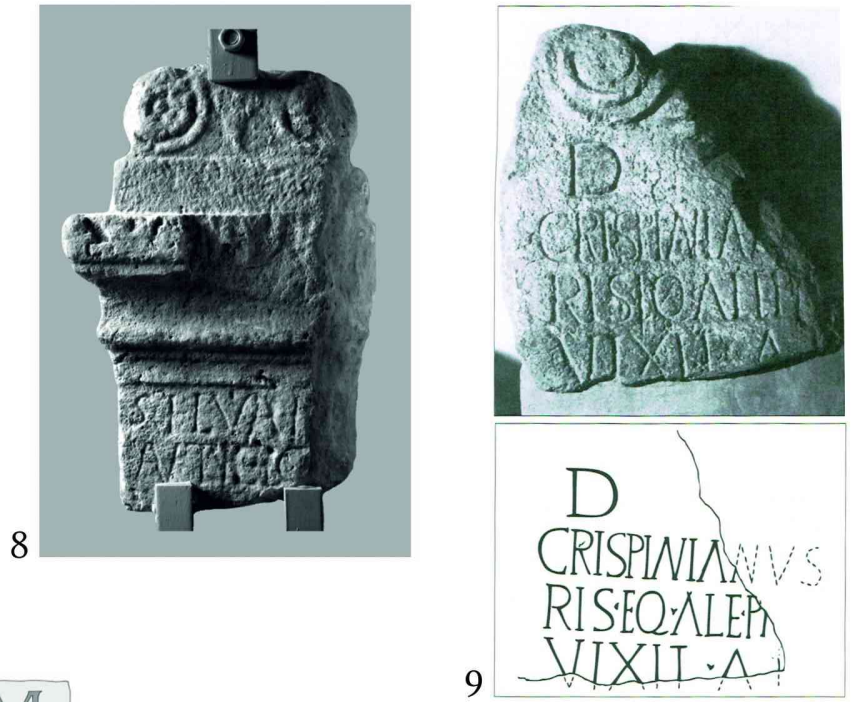

\section{,}

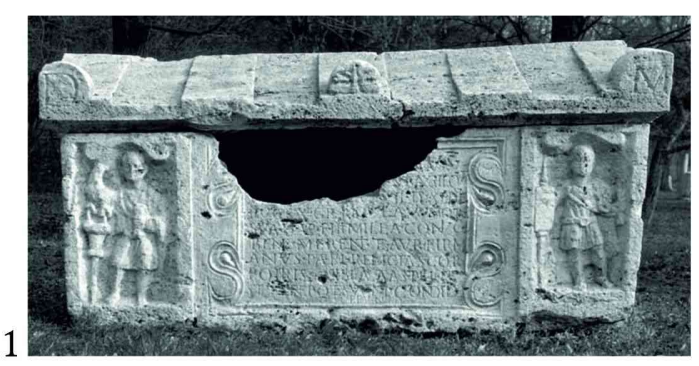

Fig. 16. Severus-kori lakosság. 1. Térdfibula (Páty). 2. Gemmával díszített bronzgyűrű (Budaörs). 3. Terra sigillata pohár a budaörsi temetőből. 4-5. M. Antonius Victorinus oltárkövei Budaörsről (MRÁv 2014). 6. Nympháknak szentelt oltárkő Pátyról (MrÁv 2007). 7. Aurelius Setanus oltárköve Budaörsről (MrÁv 2014). 8. Silvanusnak szentelt oltárkő töredék Budaörsről (MRÁv 2014). 9. Crispinianus lovaskatona sírköve Pátyról (MRÁv 2007). 10. Mithras szentély felirata Budaörsről (Mráv 2014). 11. Szarkofág a budaörsi temetőből. 

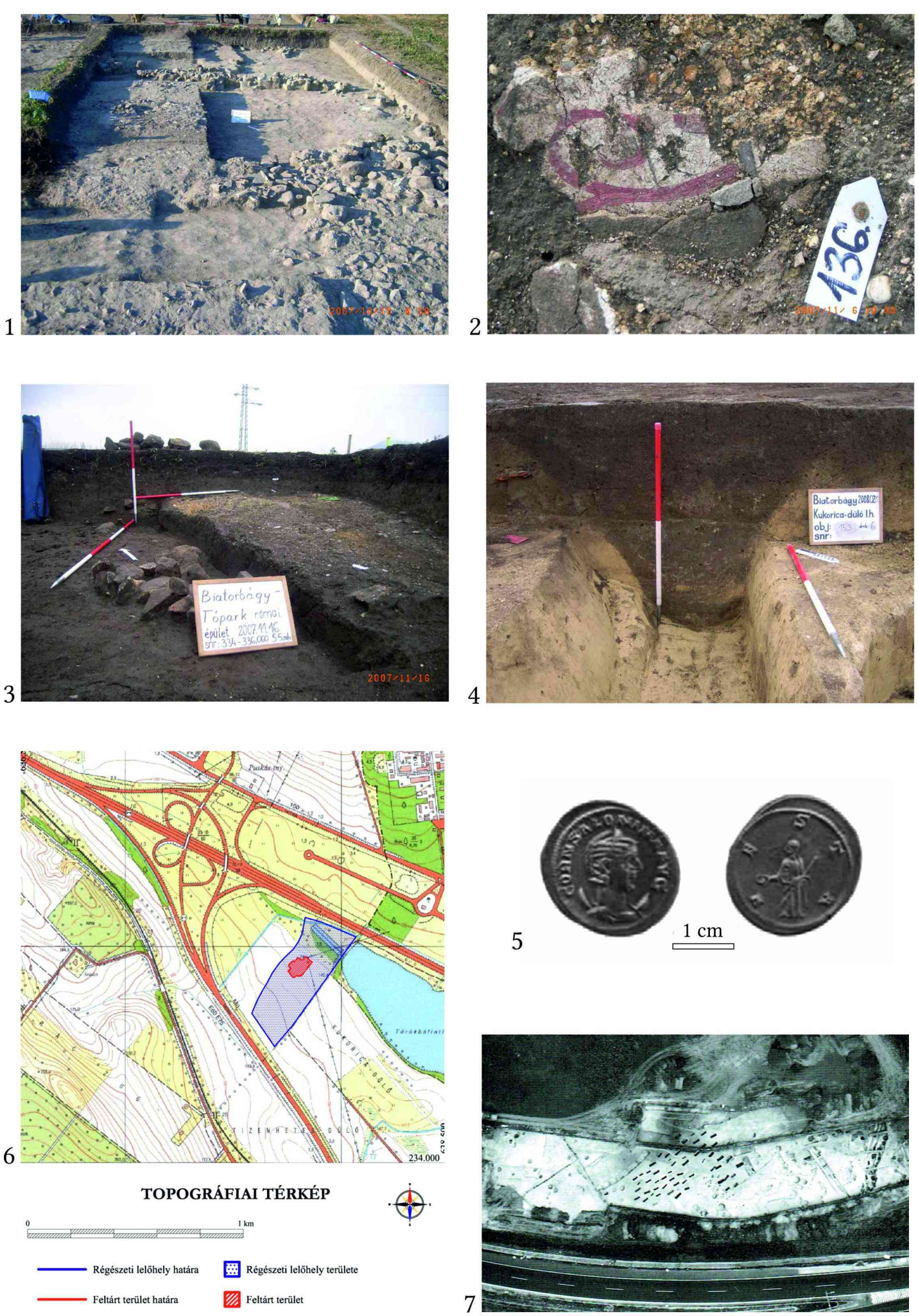

Fig. 17. Biatorbágy-Kukorica-dűlő. 1-4. Ásatási felvételek 2007-2008. 5. A 3. század közepi éremkincs egyik verete (REDő 2012). 6. A feltárás helyszínének topográfiai térképe. 7. Légifotó az M0 autópálya szélesítésének feltárásáról (REMÉNYI - TótH 2004). 

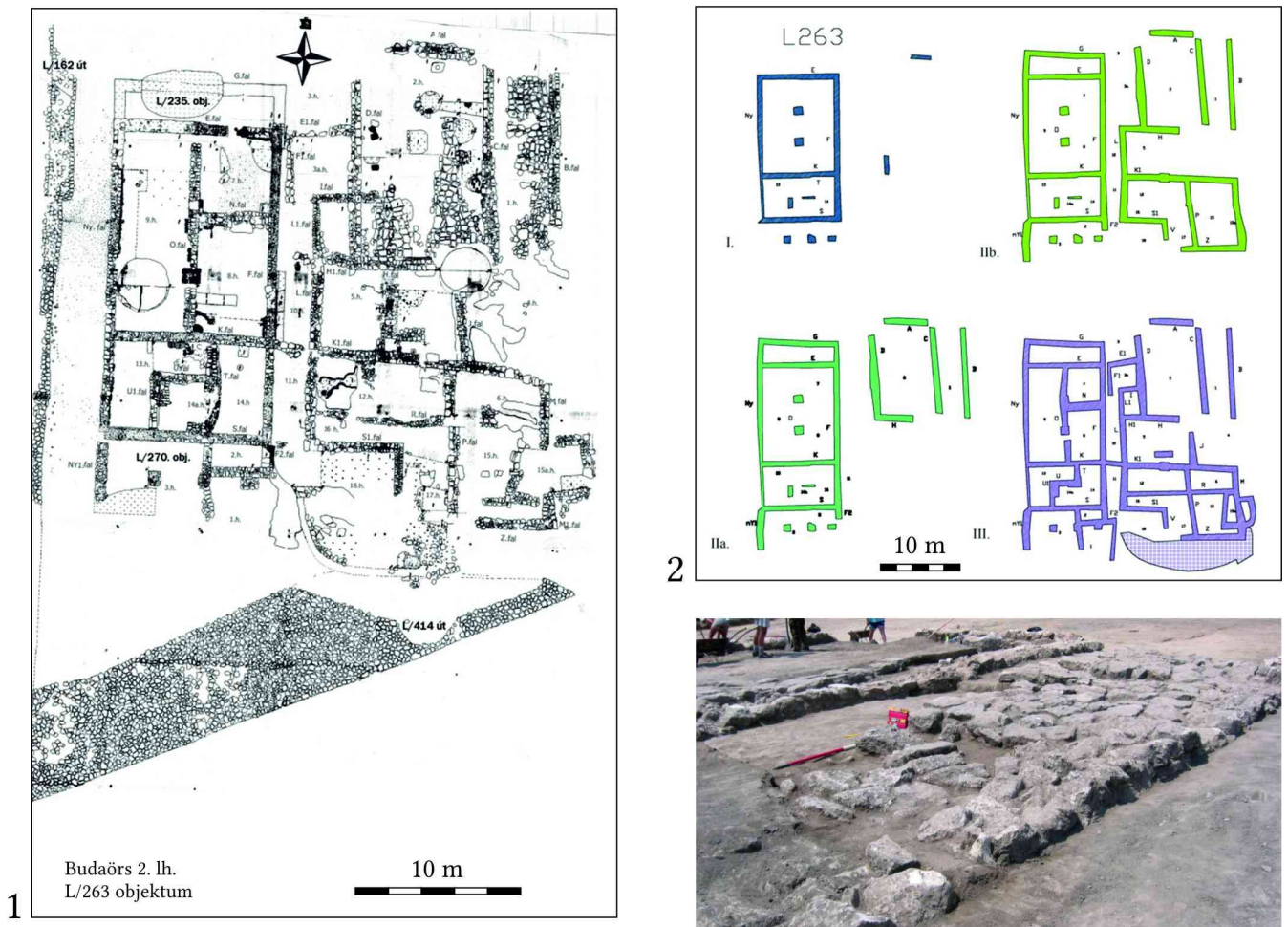

2
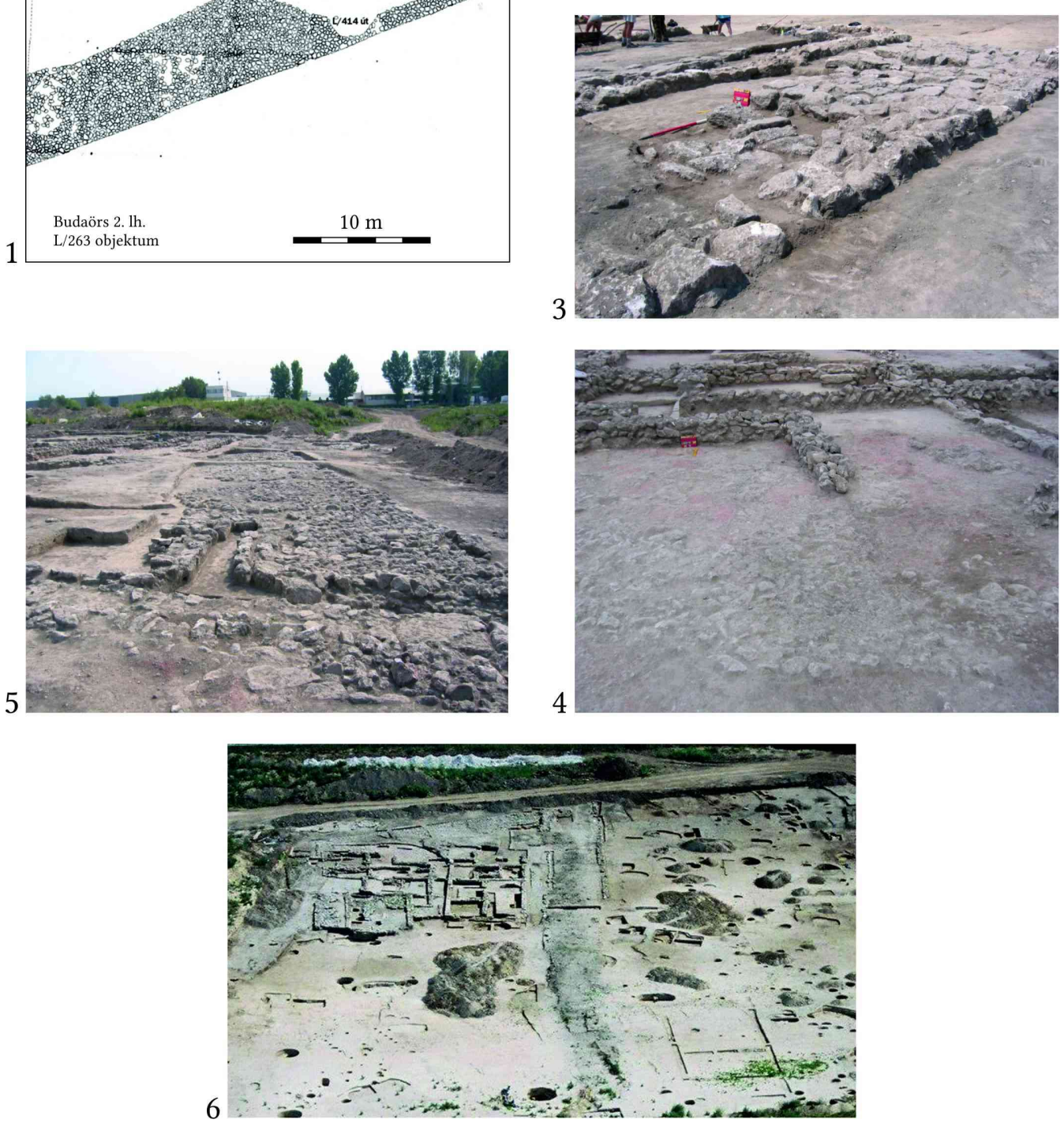

Fig. 18. A budaörsi vicus késő római fóépülete, a kövezett utak kereszteződésében.1-2. Alaprajz. 3. Kövezett belső udvar. 4. Terrazzós déli előtér. 5. Útkereszteződés pillérekkel. 6. Légifotó az útról és a főépületről (észak felől). 

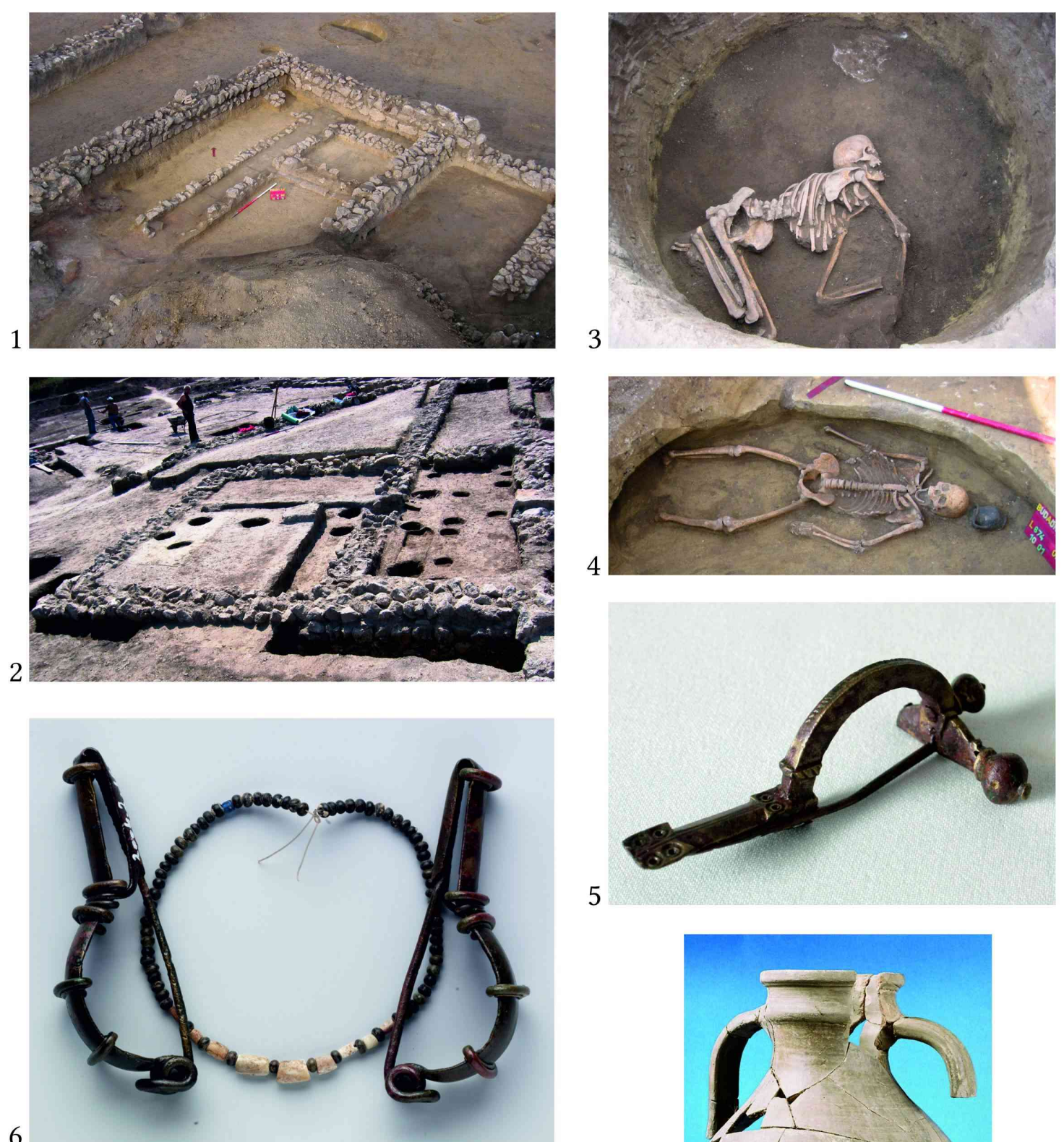

6

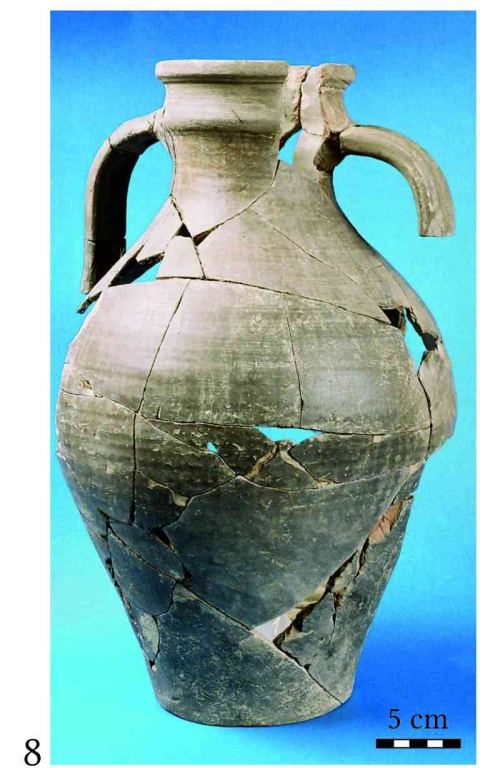

Fig. 19. Késő római kor. 1. Fütőcsatornás épület (Budaörs). 2. A budaörsi középfolyosós épületbe ásott cölöpszerkezetes, legkésőbbi építmény. 3-4. Gödörbe temetett csontvázak (Budaörs). 5. Hagymafejes fibula (Budaörs). 6. Barbár női viselet a budaörsi temetőből. 7. Kétoldalas csontfésű (Torbágy 9. lh.). 8. Galléros peremű, simított korsó (Budaörs). 

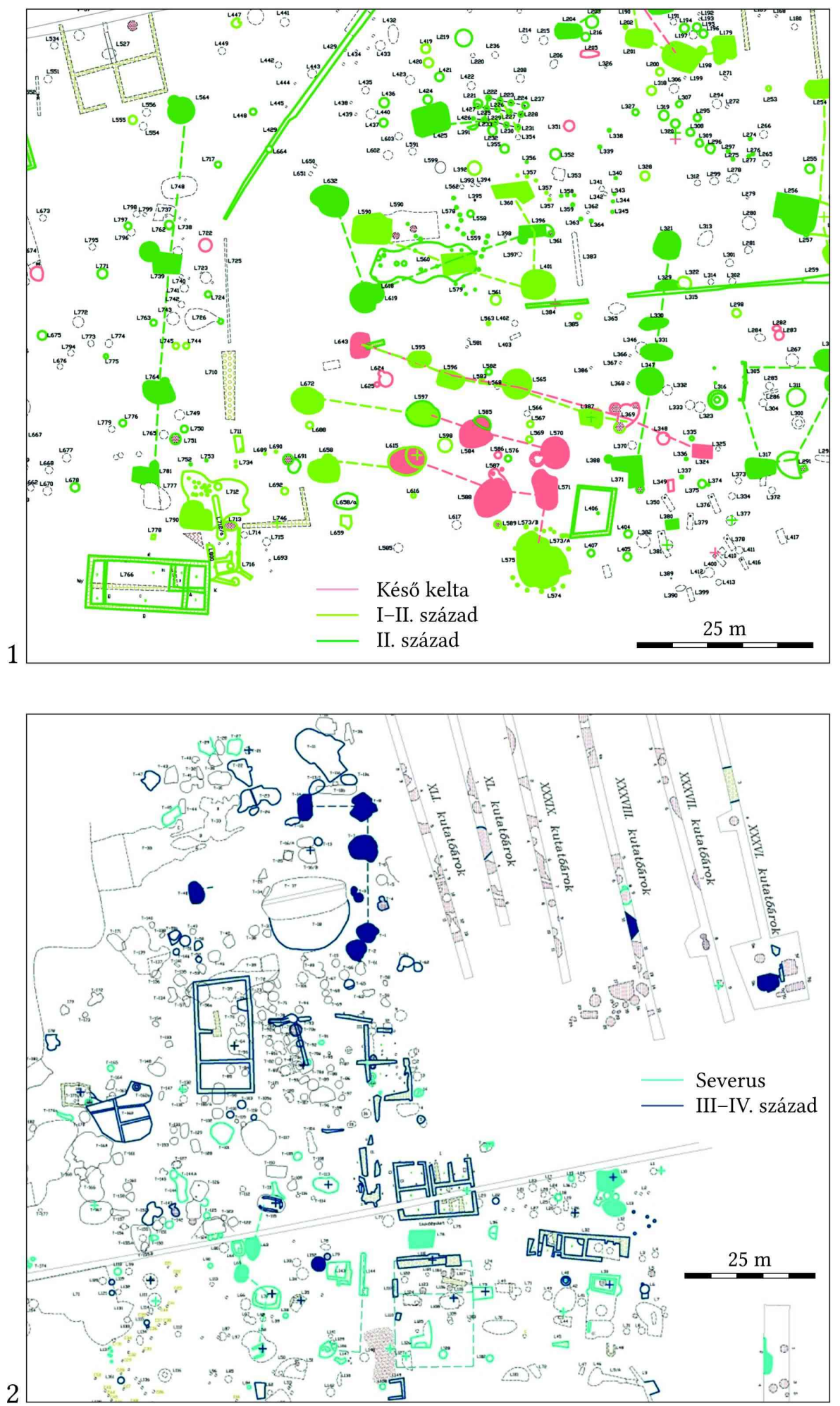

Fig. 20. 1. Kora római házsorok a budaörsi vicus patakparti részén. 2. Severus-kori és késő római műhely sorok a budaörsi vicus ÉK-i részén. 


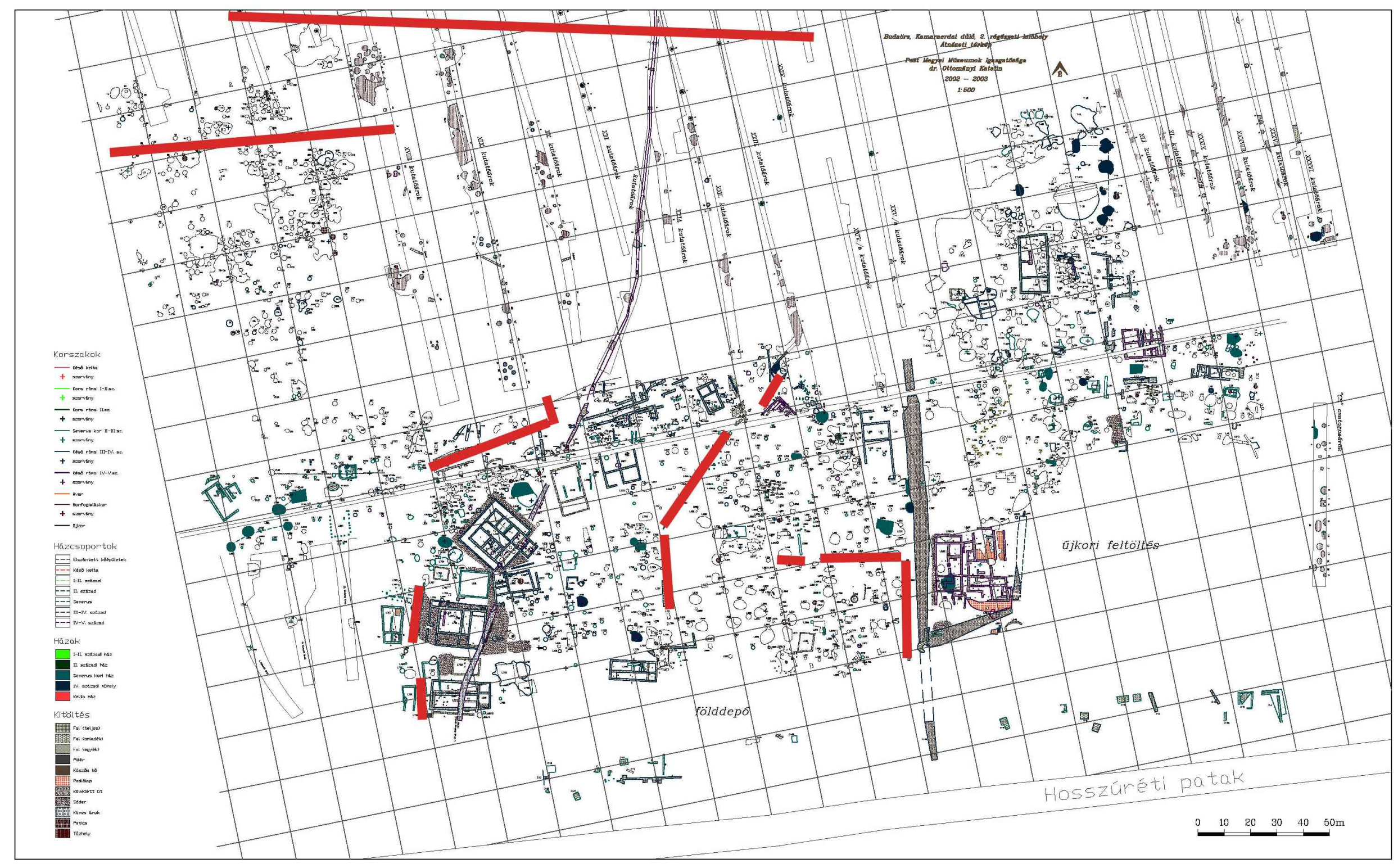

Fig. 21. A budaörsi vicus térképe a kerítésfalak, árkok és utak jelölésével. 

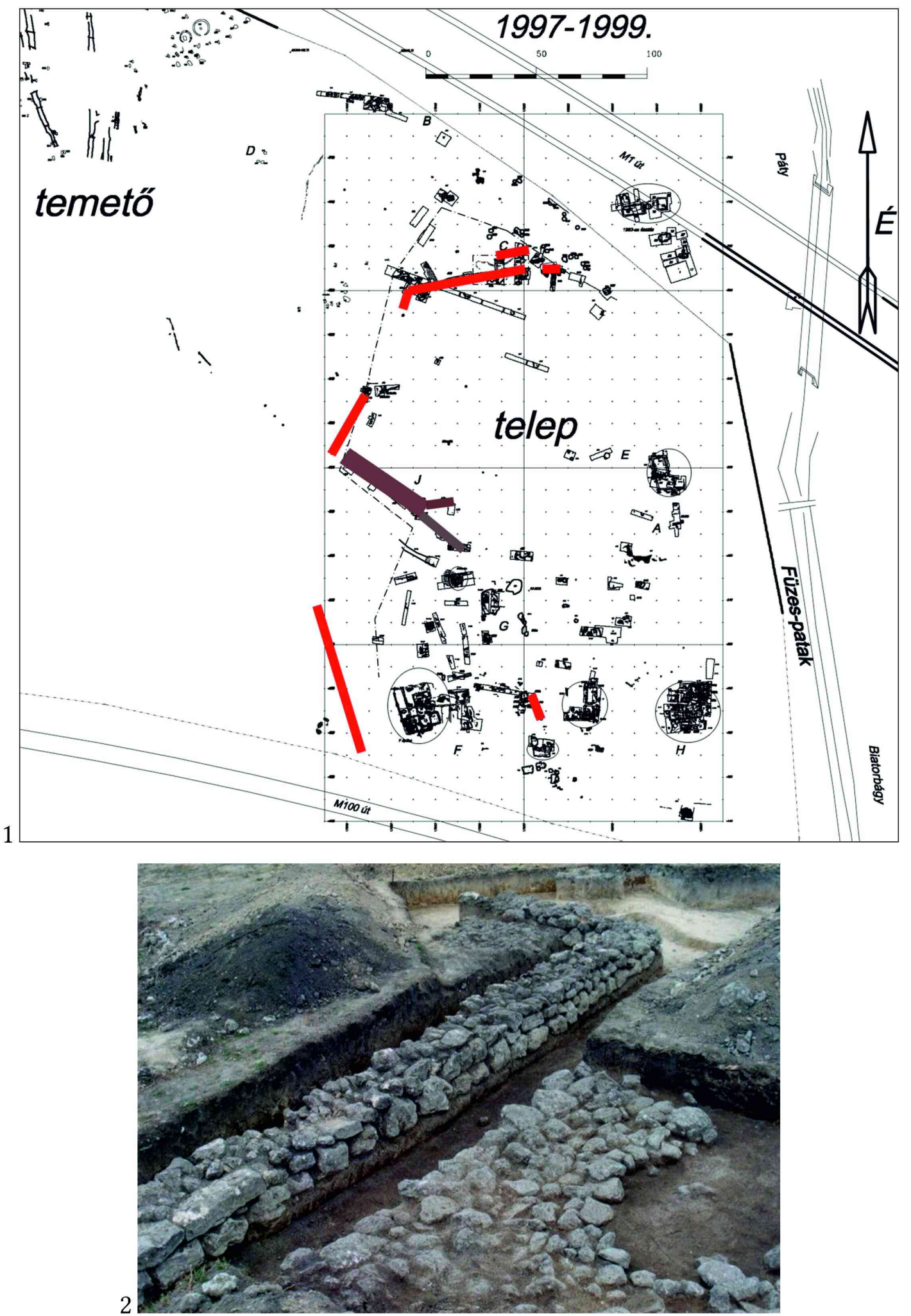

Fig. 22. 1. A pátyi vicus szerkezete kerítésfalakkal és kövezett úttal. 2. Kerítésfal és kövezett utca részlete (Páty). 

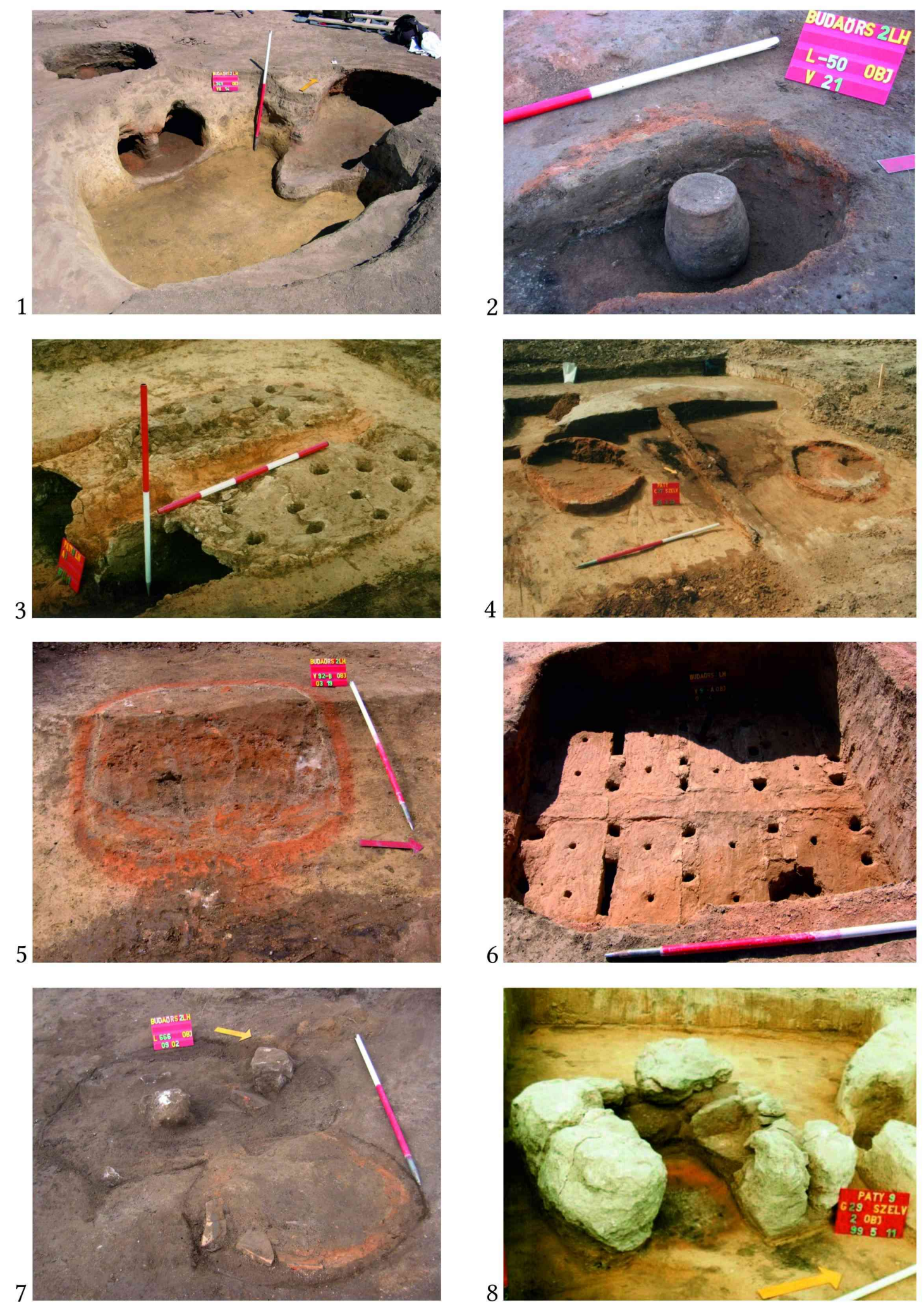

Fig. 23. Kemencék. 1. Késő kelta kemencék (Budaörs). 2. 1. századi gödörben égetés (Budaörs). 3-4. Pátyi kora római kemencék. 5-6. Szögletes edényégető kemencék (Budaörs). 7. Késő római kemence foltja (Budaörs). 8. Késő római kőkemence (Páty). 


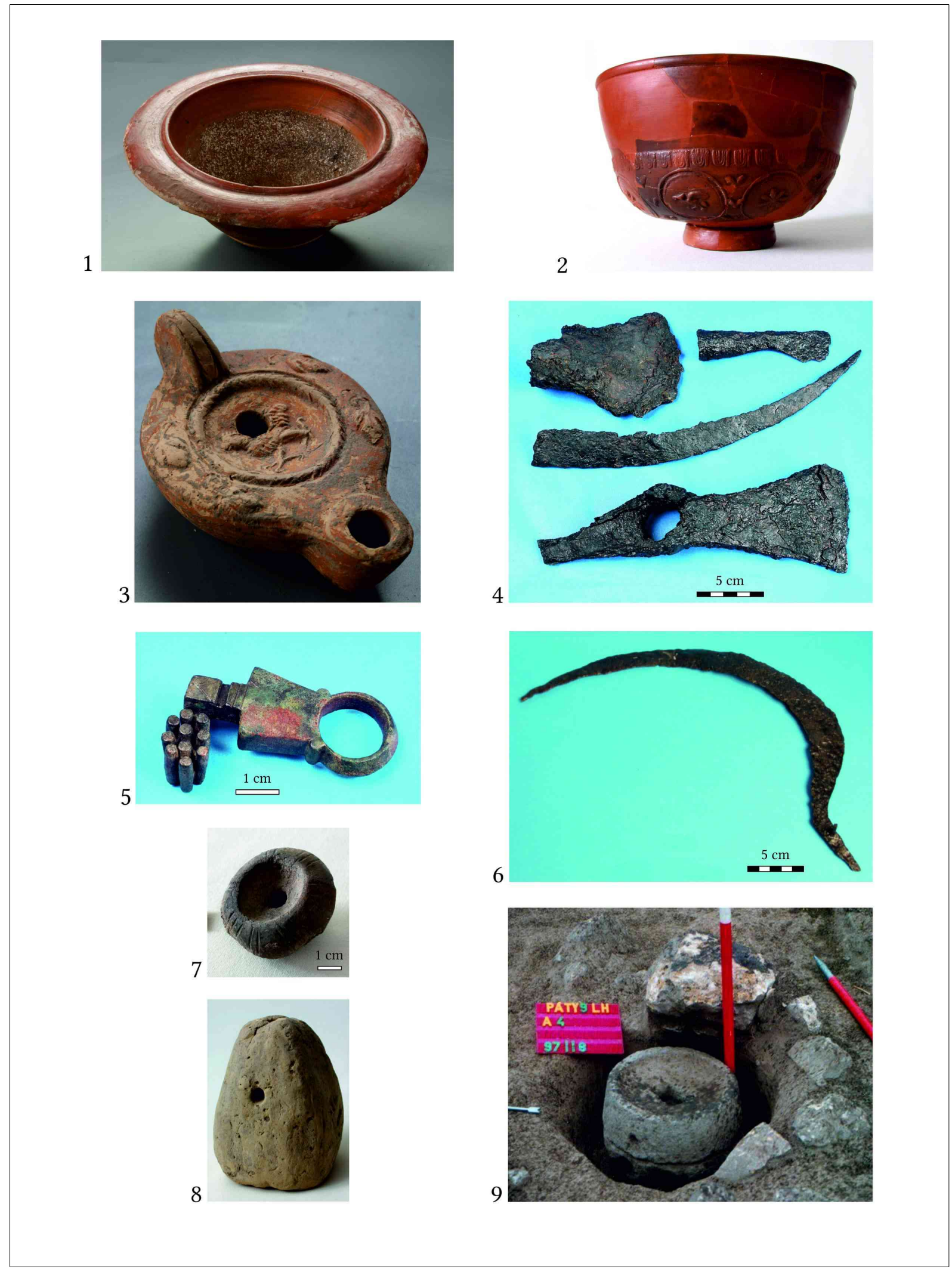

Fig. 24. Romanizáció, gazdasági élet. 1. Festett dörzstál (Páty). 2. Terra sigillata tál (Páty). 3. Állatalakos mécses (Budaörs). 4, 6. Mezőgazdasági vasszerszámok (Budaörs). 5. Bronzkulcs (Páty). 7. Orsógomb (Budaörs). 8. Szövőszéknehezék (Budaörs). 9. Kétrészes, forgatható kézi malom (Páty). 